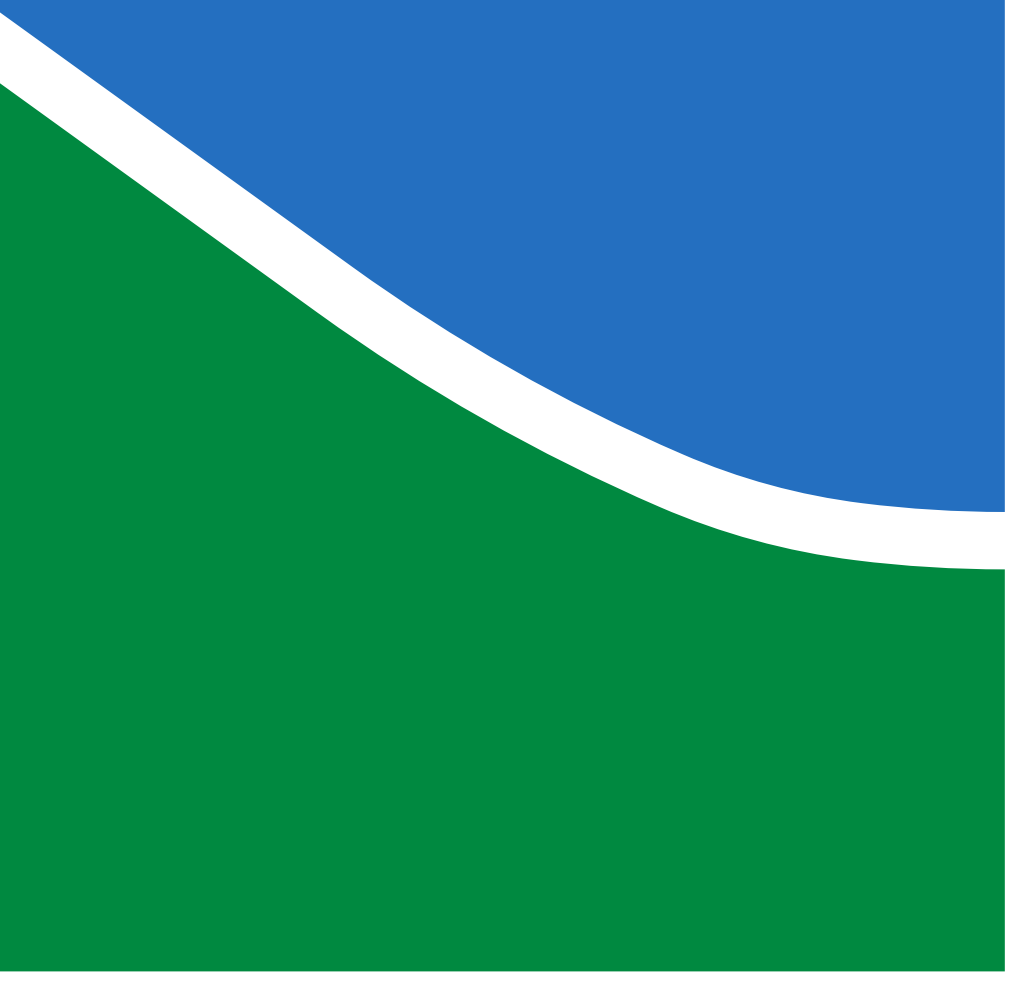

DISSERTAÇÃO DE MESTRADO

\title{
DESENVOLVIMENTO DE PRÓTESE TRANSFEMURAL ROBÓTICA: PROJETO MECÂNICO E DE ATUAÇÃO
}

Thiago Silva Rocha

\section{UNIVERSIDADE DE BRASÍLIA}




\section{UNIVERSIDADE DE BRASÍLIA \\ FACULDADE DE TECNOLOGIA \\ DEPARTAMENTO DE ENGENHARIA ELÉTRICA}

\section{DESENVOLVIMENTO DE PRÓTESE TRANSFEMURAL ROBÓTICA: PROJETO MECÂNICO E DE ATUAÇÃO}

\section{THIAGO SILVA ROCHA}

DISSERTAÇÃO DE MESTRADO SUBMETIDA AO DEPARTAMENTO DE ENGENHARIA ELÉTRICA DA FACULDADE DE TECNOLOGIA DA UNIVERSIDADE DE BRASILIA, COMO PARTE DOS REQUISITOS NECESSÁRIOS PARA A OBTENÇĀO DO GRAU DE MESTRE.

APROVADA POR:

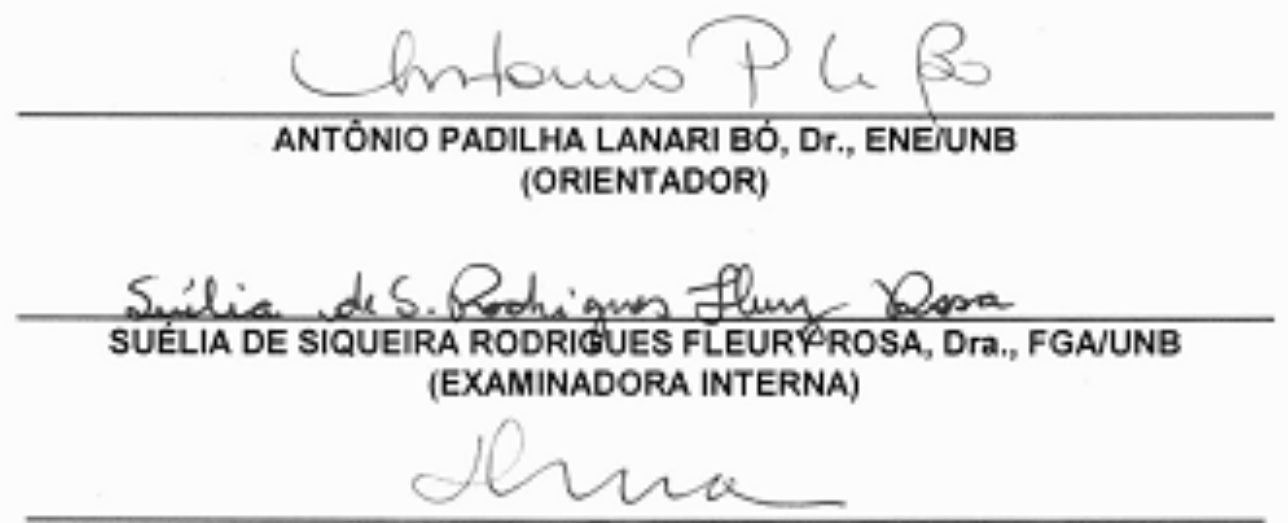

DIANNE MAGALHĀES VIANA, Dra., ENEM/FT

(EXAMINADORA EXTERNA) 


\section{FICHA CATALOGRÁFICA}

\section{THIAGO, SILVA ROCHA}

Desenvolvimento de Prótese Robótica Transfemural: Projetos Mecânico e de Atuação,

[Distrito Federal] 2015.

xii, 80p., 210 x 297 mm (ENE/FT/UnB, Mestre, Dissertação de Mestrado - Universidade de Brasília. Faculdade de Tecnologia. Departamento de Engenharia Elétrica)

1. Próteses de membro inferior

2. Robótica de reabilitação

3. Joelho policêntrico

4. Atuador magneto-reológico

I. $\mathrm{ENE} / \mathrm{FT} / \mathrm{UnB}$

II. Título (Série)

\section{REFERÊNCIA BIBLIOGRÁFICA}

ROCHA, T. S. (2011). Desenvolvimento de Prótese Robótica Transfemural: Projetos Mecânico e de Atuação. Dissertação de Mestrado em Engenharia de Sistemas Eletrônicos e Automação, Publicação PGEA.DM-622/16, Faculdade de Tecnologia, Universidade de Brasília, Brasília, DF, $80 \mathrm{p}$.

\section{CESSÃO DE DIREITOS}

AUTOR: Thiago Silva Rocha

TÍTULO: Desenvolvimento de Prótese Robótica Transfemural: Projetos Mecânico e de Atuação.

GRAU: Mestre

ANO: 2015

É concedida à Universidade de Brasília permissão para reproduzir cópias desta dissertação de mestrado e para emprestar ou vender tais cópias somente para propósitos acadêmicos e científicos. O autor reserva outros direitos de publicação e nenhuma parte desse Trabalho de Graduação pode ser reproduzida sem autorização por escrito do autor.

Thiago Silva Rocha

SCLRN 707 Bloco C, Número 15, Apartamento 201 - Asa Norte.

70740-533 Brasília - DF - Brasil. 
Dedicatória

À minha mãe, Eida Conceição Silva.

Thiago Silva Rocha 


\section{Agradecimentos}

Agradeço a todos que tornaram possivel a conclusão desse trabalho.

Thiago Silva Rocha 


\title{
RESUMO
}

A presente dissertação de mestrado descreve o projeto e o desenvolvimento de uma prótese transfemural robótica, em especial o design mecânico e o sistema de atuação. O mecanismo do joelho, construído para apresentar uma movimentação policêntrica, foi baseado em um arranjo de quatro barras, pemitindo um posicionamento conveniente do centro instantâneo de rotação durante a as diversas fases marcha. Essa configuração confere maior estabilidade e controlabilidade ao usuário e maior conforto em movimento. O sistema de atuação consiste de um pistão magnetoreológico que funciona como amortecedor de amortecimento variável controlável por corrente elétrica. São apresentados também a eletrônica embarcada no dispositivo e os sensores instalados para a medição de diversas variáveis da marcha. Os experimentos realizados com um voluntário amputado, também aqui apresentados, permitem concluir que o dispositivo confeccionado é funcional como prótese e capaz de possibilitar ao usuário marcha confortável ao usuário, com maior dinamismo e segurança para o usuário. Os experimentos também apontam diversas possibilidades de aprimoramento do dispositivo.

Palavras Chave: Próteses de membro inferior, Robótica de reabilitação, Joelho policêntrico, Atuador magneto-reológico.

\begin{abstract}
This master thesis describes the design and development of a transfemoral robotic prosthesis, especially the mechanical design and the actuation system. The knee mechanism, built to present a polycentric movement, was based in a four bar linkage, enabling a convenient positioning of the instantaneous center of rotation during the different phases of gait. This configuration provides greater stability and controllability to the user and greater comfort in motion. The actuation system consists of a magnetorheological piston which acts as damper with variable damping controllable by electrical current. The paper also presents the embedded electronics and the sensor system for measuring different gait variables. The experiments carried out with an amputated volunteer, also presented here, demonstrates that the built device is functional as a prosthesis and grants to the user comfortable gait with greater dynamism and safety. The experiments also point to several device enhancement possibilities.
\end{abstract}

Keywords: Lower limb prostheses, Rehabilitation robotics, Polycentric knee, Magnetorheological actuator. 


\section{SUMÁRIO}

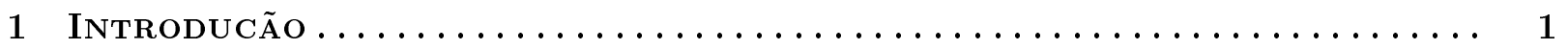

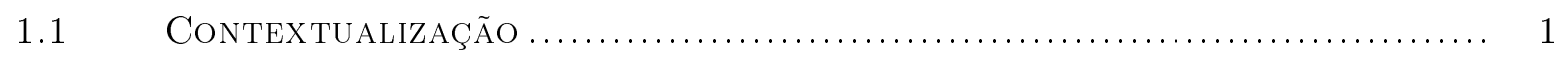

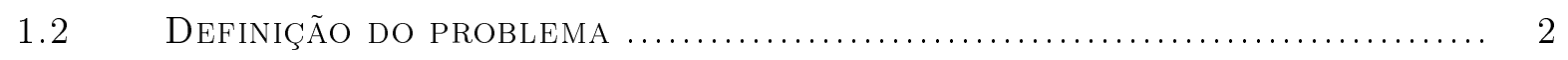

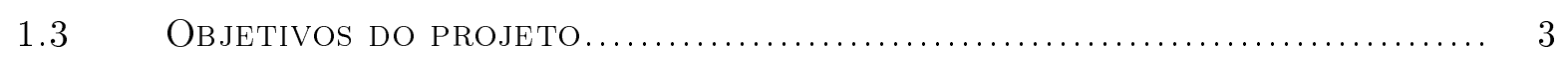

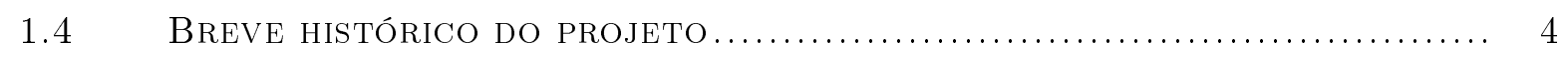

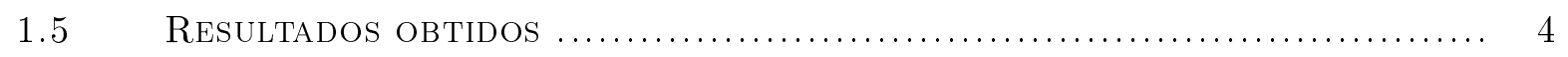

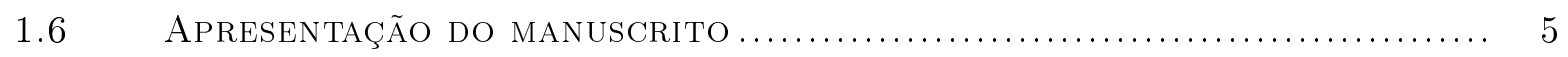

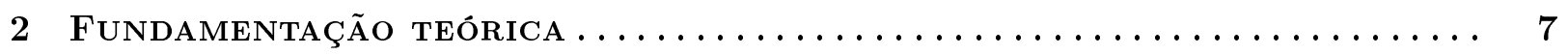

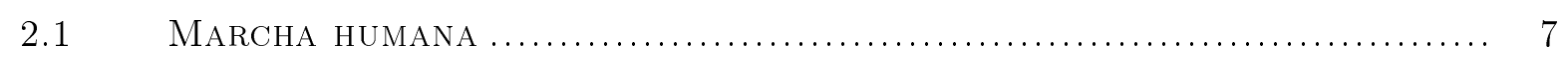

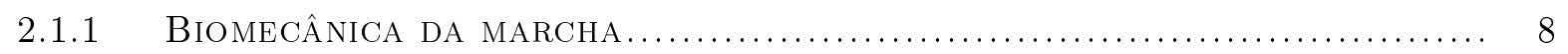

2.2 Aspectos gerais de PRóteses de MEMBRo INFERIOR .................... 14

2.2.1 COMPONENTES BÁSICOS DE PRÓTESES DE MEMBRO INFERIOR ................ 15

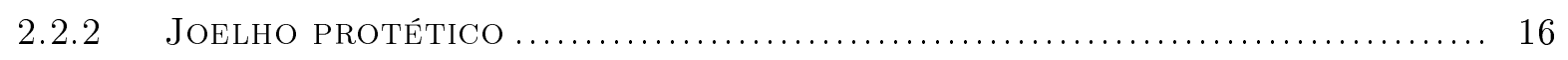

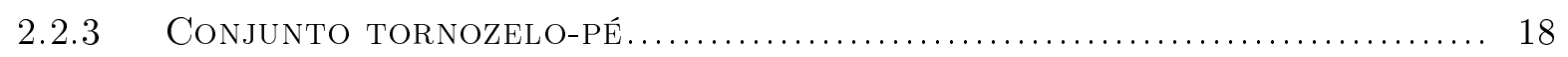

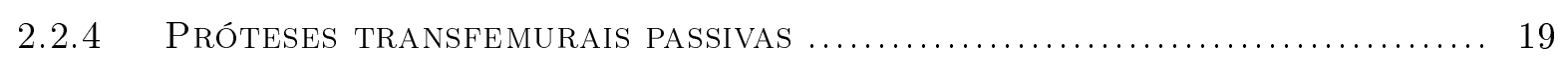

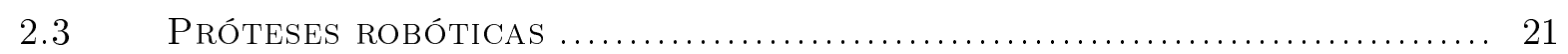

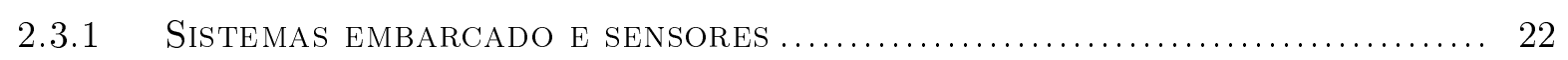

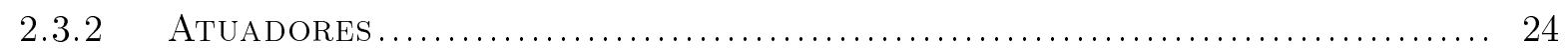

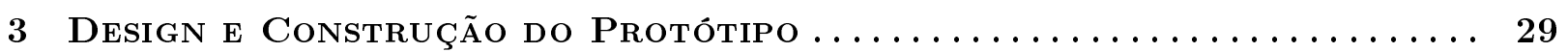

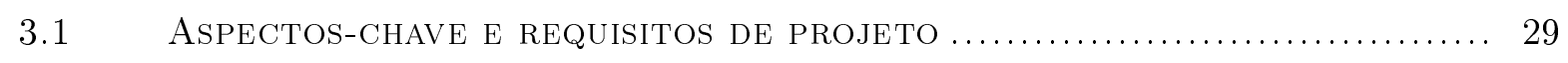

3.2 O MECANISMO DE QUATRO BARRAS .................................. 31

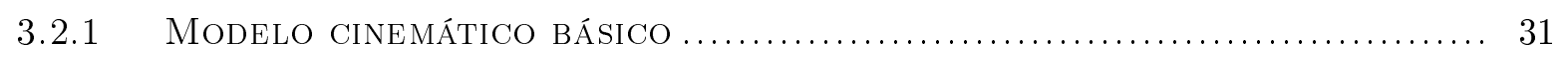

3.2.2 O POSICIONAMENTO DO CENTRO InStANTÂNEO DE ROTAÇÃO................... 34

3.2.3 O ENCURTAMENTO APARENTE DO MECANISMO DE QUATRO BARRAS........... 35

3.3 MODELAGEM MECÂNICA DO JOELHO PROTÉTICO .......................... 37

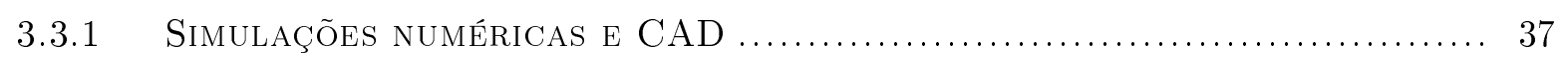

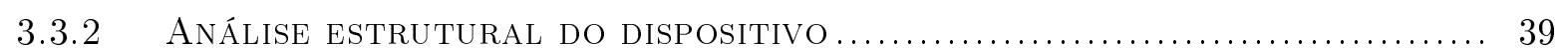

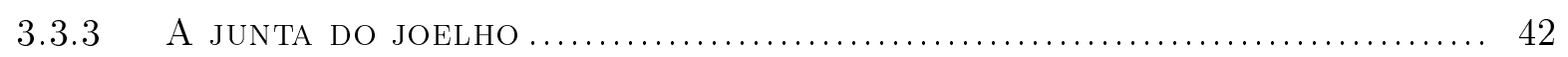

3.4 Atuador magneto-Reológico e seu acionamento $\ldots \ldots \ldots \ldots \ldots \ldots \ldots \ldots \ldots . . \ldots 7$

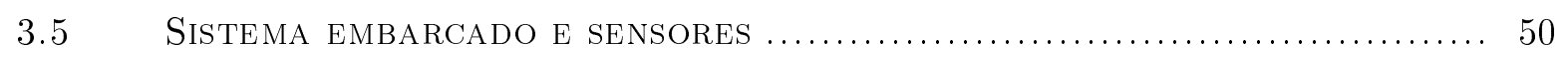




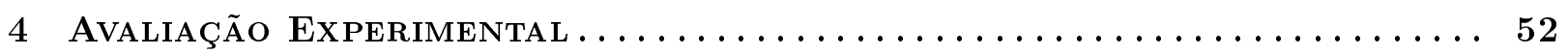

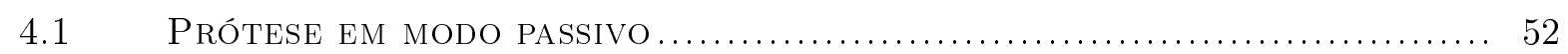

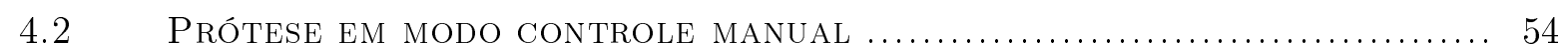

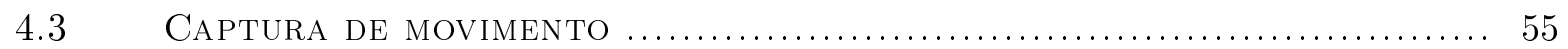

5 Conclusões e Trabalhos Futuros $\ldots \ldots \ldots \ldots \ldots \ldots \ldots \ldots \ldots \ldots \ldots$

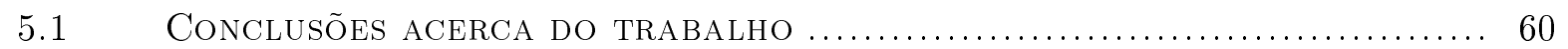

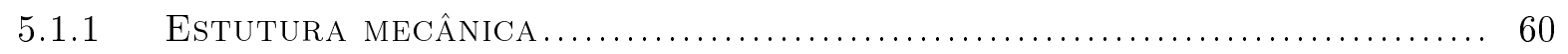

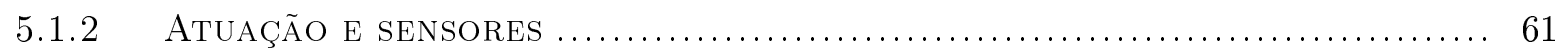

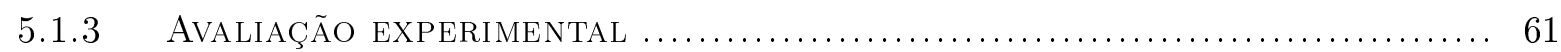

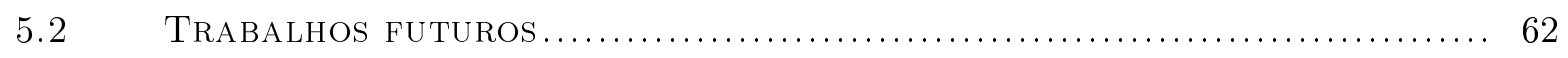

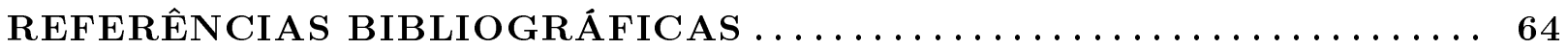




\section{LISTA DE FIGURAS}

1.1 Níveis de amputação de membro inferior.

1.2 Evolução dos protótipos de bancada produzidos no âmbito dos projetos de pesquisa em tecnologia assistiva $(2005-2010)$

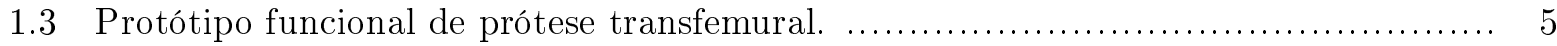

2.1 Ciclo de marcha com suas fases e eventos característicos.............................. 7

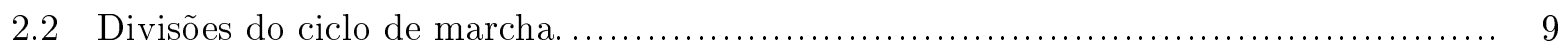

2.3 Variação angular do joelho durante um ciclo de marcha............................... 9

2.4 Torque por unidade de massa no joelho durante um ciclo de marcha.................. 10

2.5 Potência por unidade de massa no joelho durante um ciclo de marcha................ 11

2.6 Sinal de EMG de músculos da coxa: biceps femoris (flexor do joelho) e vasti (con-

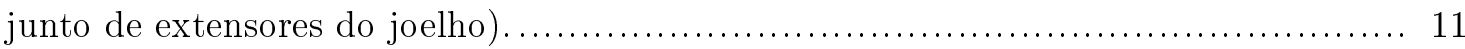

2.7 Variação angular do tornozelo durante um ciclo de marcha. ........................... 12

2.8 Torque por unidade de massa no tornozelo durante um ciclo de marcha............... 12

2.9 Potência por unidade de massa no tornozelo durante um ciclo de marcha.............. 13

2.10 Sinal de EMG de músculos da perna: tibialis anterior (dorsiflexor) e soleus (plan-

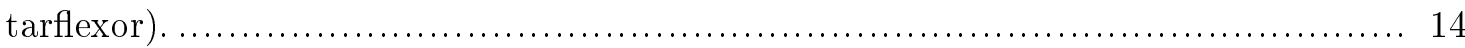

2.11 Prótese transfemural típica, com destaque aos quatro elementos principais que a

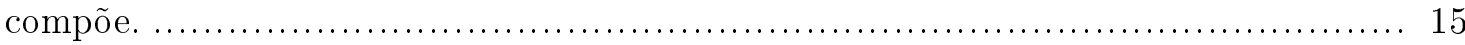

2.12 Dois modelos de joelhos protéticos comerciais fabricados pela Ottobock ${ }^{\circledR}$, Alemanha: (a) Joelho monocêntrico 3R80; (b) Joelho policêntrico $3 R 78 \ldots \ldots \ldots \ldots \ldots \ldots \ldots \ldots \ldots \ldots$

2.13 Travamento do joelho em extensão total durante o suporte. A linha amarela representa a linha de carga do indivíduo e a os arcos vermelhos com seus respectivos centros mostram os sentidos dos torques de reação aplicados pelos tendões nas juntas

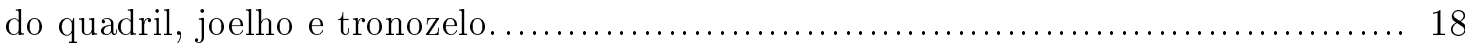

2.14 Exemplos pés protéticos. (a) Pé SACH 1K30 da Ottobock; (b) Pé de carbono 1C30 Trias da Ottobock; (c) Pé robótico com tornozelo articulado Proprio Foot da Össur.. 19

2.15 Variação angular comparada entre joelho de indivíduo sem amputação (laranja) e

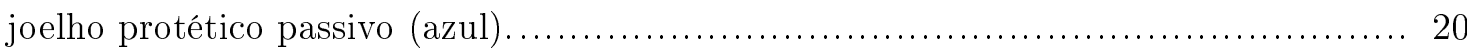

2.16 Diagrama sistemático generalizado de uma prótese robótica. ........................ 21

2.17 Joelho protético microprocessado C-Leg da Ottobock. .............................. 22

2.18 Prótese transtibial robótica BiOM, da BiOM Personal Bionics.......................... 23

2.19 Modelo CAD e fotografia de prótese transtibial robótica atuada por motor, SPARKy. 24

2.20 Fotografia de prótese transfemural robótica atuada por pistões pneumáticos........... 25 
2.21 Diagrama simplificado de um pistão magneto-reológico com seus principais componentes.

2.22 Fotografia de um pistão MR com um esquema em corte exibindo detalhes da estrutura interna do mesmo juntamente com uma representação do campo magnético

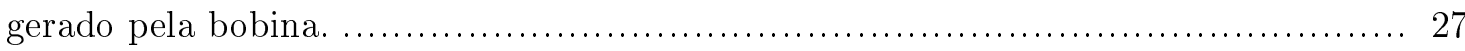

2.23 Dinâmica do pistão

2.24 Resposta característica de um pistão magneto-reológico para três níveis de corrente: $0 ; 0,5 \mathrm{~A}$ e $1 \mathrm{~A}$.

3.1 Protótipo em dois momentos: (a) montado e com o atuador acoplado, ainda com soquete provisório; (b) protótipo funcional, com sistema embarcado e sensores acoplados.

3.2 Arranjo de quatro barras genérico (barras e juntas rotacionais representadas em preto).

3.3 Arranjo de quatro barras em suas configurações: (a) Fechada; (b) Cruzada.

3.4 Exemplo genérico do posicionamento de um CIR do arranjo de quatro barras......... 34

3.5 Exemplo genérico da alteração da distâncias entre pontos fixos a duas barras do arranjo de quatro barras.

3.6 Posições da simulação do arranjo de quatro barras mostradas sequencialmente de (a) até (d). Em magenta estão representadas as posições do CIR e sua evolução. ..... 38

3.7 Modelo CAD final do mecanismo representado em diferentes posicionamentos.

3.8 Imagem em escala de cores para as tensões de von Mises para as peças do joelho. (a)Tensões de 0,02MPa a 7,3MPa. (b)Tensões de 0,05MPa a $372 M P a$. (c)Tensões de 0,13MPa a 65MPa. (d)Tensões de 0,02MPa a 53MPa......

3.9 Imagem da malha de simulação utilizada pelo software de CAD executar a FEA. Fonte: [1].

3.10 Distribuição de tensões ao longo de toda a estrutura do protótipo. Fonte: [1] .... 43

3.11 Detalhe do ponto de maior concentração de tensões ao longo da estrutura do protótipo. Fonte: [1]

3.12 Desenho em escala das barras teóricas, suas dimensões e posicionamentos na configuração completamente extendida do joelho, além de uma ilustração exemplificando a prótese completa. As juntas entre as barras são numeradas de 0 a 3 . Na posição totalmente extendida do joelho o ângulo $\alpha$ é igual $88,61^{\circ}$.

3.13 Movimentação do mecanismo e evolução do centro instantâneo de rotação em função do ângulo do joelho. A linha azul representa a trajetória do CIR e em verde tracejado estão representadas verticalmente a linha de carga e horizontalmente uma linha passante pelo eixo de rotação da peça superior do mecanismo, solidária ao soquete... 45

3.14 Foto de um indivíduo com amputação transfemural utilizando o protótipo. Destaque para o posicionamento da linha de carga (em verde) em relação ao centro instantâneo de rotação (ponto de encontro entre as linhas pontilhadas em vermelho).

3.15 Desenho CAD e protótipo real do mecanismo do joelho com destaque para as barras em verde. 
3.16 Esquemático do pistão MR RD-8040-1, Lord Corporation (dimensões em milímetros). Adaptado de [lord]

3.17 Esquemático do posicionamento do pistão na estrutura mecânica. .................... 49

3.18 Sistema embarcado da prótese. (a) Encoder; (b) Leitor do cartão de memória; (c) Módulo de transmissão sem fio; (d) Placa principal contendo a unidade computacional, o driver de potência, a central inercial e os circuitos de condicionamento de sinal; (e) Bateria; (f) Colocação do sistema embarcado na prótese.

4.1 Fotografia de voluntário amputado caminhando com a prótese em modo passivo. .... 53

4.2 Voluntário caminhando em uma esteira com a prótese em modo controle manual..... 54

4.3 Voluntário durante o experimento de captura de movimento. (a) Estático em vista frontal; (b) Estático em vista lateral; (c) Voluntário caminhando em uma esteira com a prótese em modo de identificação.

4.4 Variação angular comparada entre joelho de indivíduo sem amputação (laranja tracejado), joelho protético em modo passivo (azul) e joelho saudável de indivíduo amputado (verde) durante um ciclo de marcha.

4.5 Variação angular (verde), velocidade angular (vermelho tracejado) e aceleração angular (azul) do joelho protético em três ciclos de marcha consecutivos. Destaque para instantes de ocorrência dos eventos da marcha (linhas pretas tracejadas)..... 


\section{LISTA DE TABELAS}

3.1 Parâmetros estruturais das peças componentes do protótipo....................... 40

3.2 Dimensões das barras teóricas do protótipo. ...................................... 43 


\section{Capítulo 1}

\section{Introducão}

\subsection{Contextualização}

"A remoção cirúrgica de parte do corpo, um membro ou parte de um membro para tratar infecção recorrente ou gangrena em doença vascular periférica; para remover tumores malignos; e para tratar trauma severo... Tipos de amputação incluem amputação fechada, amputação congênita, amputação aberta, amputação primária e amputação secundária." Assim, de maneira bastante ampla, o dicionário de medicina [2] define este que é o primeiro procedimento cirúrgico conhecido [3]: a amputação. Podendo ser um procedimento planejado ou de emergência, a cirurgia de amputação tem basicamente dois objetivos: a remoção de tecido doente de forma que a ferida se cure de modo limpo e a construção de um coto de amputação que irá permitir o acoplamento de uma prótese ou outra peça artificial de reposição[4].

Em se tratando de amputações de membro inferior é possível classificá-las em diversos níveis que se referem à posição onde é feita amputação. São seis tipos básicos, em ordem crescente de altura da amputação: amputação de pé, amputação transtibial, desarticulação de joelho, amputação transfemural, desarticulação de quadril e hemipelvectomia ${ }^{1}$. A figura 1.1 mostra uma sequiência de desenhos obtidos em [6] que exemplificam as seis classificações básicas para amputações de membro inferior.

Cada nível básico de amputação recebe uma indicativa de protetização específica para o tipo de amputação dada por uma equipe médica e técnica[6]. No caso de amputações de membro inferior, mais especificamente a amputação transfemural - matéria deste trabalho e que compreende todas as amputações feitas na altura do fêmur -, a indicação de protetização é bastante alta. Entende-se por protetização todo o processo que permite ao amputado o uso de uma prótese funcional ou cosmética, compreendendo desde a cirurgia de amputação até o treinamento de uso da prótese.

Os principais objetivos do uso de uma prótese de membro inferior são a promoção de marcha confortável, segura e mais natural possível ao usuário, nas mais diversas atividades que ele desejar executar. Em grande parte dos casos o uso desse tipo de prótese dá ao usuário uma capacidade

\footnotetext{
${ }^{1}$ Uma melhor compreensão das regiões anatômicas envolvidas pode ser obtida em [5].
} 


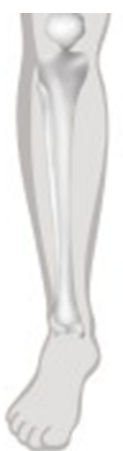

(a)

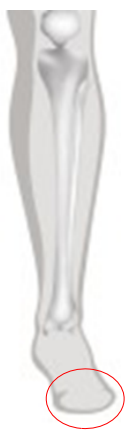

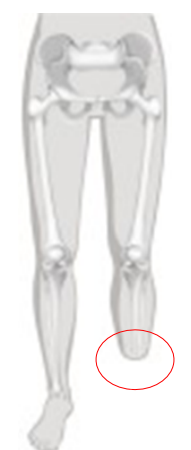

(b)

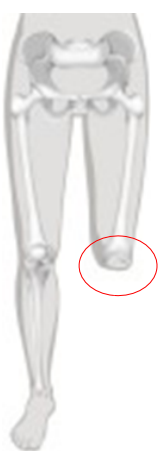

(c)

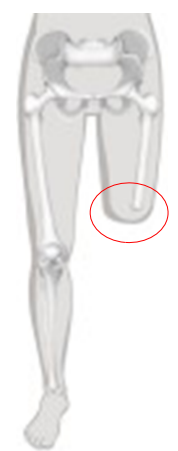

(d)

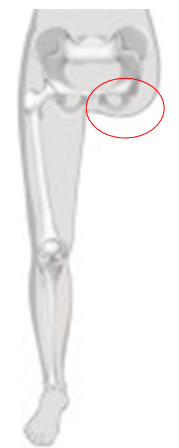

(e)

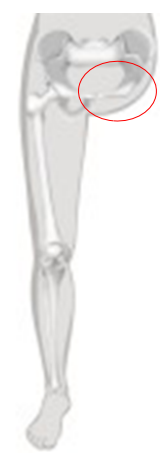

(f)

Figura 1.1: Níveis de amputação de membro inferior: (a) de pé, (b) transtibial, (c) desarticulação de joelho, (d) transfemural, (e) desarticulação de quadril e (f) hemipelvectomia. Fonte[6].

de movimentação comparável à do membro saudável. Já é bastante difundido o uso de próteses convencionais de membro inferior. Mais acessíveis - inclusive distribuídas gratuitamente pelo Sistema Único de Saúde no Brasil - e simples, são sempre a primeira alternativa de protetização para o recém amputado. Entretanto, muitos são os casos de amputações muito severas que reduzem consideravelmente a quantidade e qualidade da movimentação possível de ser desenvolvida pelo usuário. Nesses casos o tamanho do membro residual, que é o principal responsável pelo controle da prótese, é bastante reduzido, o que limita bastante a movimentação em termos de força, velocidade e controle da prótese, além de exigir um trabalho físico muito extenuante do usuário.

Nesse contexto, o desenvolvimento de próteses robóticas, que sejam capazes de detectar a intenção de movimento do usuário e executar a tarefa pretendida, surge como uma excelente alternativa para promover uma maior qualidade de vida ao paciente amputado, já que estas podem permitir que o usuário execute atividades cotidianas - caminhar, subir e descer escada e rampas, levantar de uma cadeira, etc. - com maior facilidade. Uma prótese robótica é um dispositivo inteligente com algum grau de autonomia, capaz de tomar decisões e executar ações funcionalmente semelhantes às partes do corpo substituídas, utilizando uma fonte de energia externa ao usuário para isso.

\subsection{Definição do problema}

Não existem dados oficiais consolidados para a incidência amputações de membro inferior no Brasil mas estima-se que anualmente ocorram 13,9 amputações somente desse tipo para cada 100000 habitantes $[7]^{2}$. Isso representa pouco menos de 28000 brasileiros que todos os anos perdem ao menos uma parte do membro inferior e, potencialmente, recebendo indicação médica para a protetização.

É notável o crescimento da variedade de próteses robóticas no mercado internacional bem como o número de trabalhos científicos sobre esse tipo de prótese em desenvolvimento no mundo, entretanto, devido a fatores como altos custos e dificuldade de adaptação do paciente à prótese, ainda

\footnotetext{
${ }^{2}$ Dados obtidos para a cidade do Rio de Janeiro.
} 
é muito incomum a utilização desse tipo de prótese, especialmente no Brasil, que não possui fabricação nacional desse tipo de prótese. De fato, muito embora a maioria dos indivíduos amputados possa ter elevado benefício funcional ao utilizar uma prótese robótica, a relação custo-benefício atualmente não se justifica no Brasil. Dessa forma, alguns amputados, sobretudo aqueles que não apresentam alto nível de atividade física, acabam por optar por próteses mais simples, até mesmo dispositivos sem nenhuma articulação.

Uma prótese transfemural robótica chega a custar entre $U S \$ 20000$ e $U S \$ 30000$ no exterior[8], segundo dados recentes. Se adicionados o custo de importação, câmbio, taxação e de protetização, a soma se torna proibitiva para a maior parte da população do país.

O outro fator dificultante mencionado, a adaptação do usuário à prótese, se mostra por diversas vezes bastante problemático. Enquanto uma prótese convencional, não-inteligente, só se movimenta através do esforço mecânico do usuário diretamente sobre ela, a prótese inteligente, por definição, é capaz de tomar decisões e executar ações de maneira autônoma à partir do que ela consegue entender como sendo a intensão de movimento do usuário. Entretanto, a forma como o usuário informa à prótese a sua intensão em geral não é trivial. Por se tratar de uma prótese dita inteligente, muitas vezes o usuário espera que ele consiga movimentá-la exatamente como fazia com sua perna saudável, o que certamente não é o caso. Para movimentar naturalmente a perna inúmeras conexões neurais são ativadas mesmo que de maneira inconsciente, conexões essas que são interrompidas com a amputação. Da mesma maneira que essas conexões são formadas quando se aprende a andar, o amputado deve ser treinado para aprender a andar novamente mas com uma prótese.

\subsection{Objetivos do projeto}

Diante dos fatos apresentados é possível concluir que as opções de próteses robóticas não são acessíveis ao grande público, em virtude do alto preço dessas e do fato de não existir produção nacional, ainda que existam muitos amputados que poderiam se beneficiar com o uso desse tipo de prótese. Em resumo, existe no Brasil uma demanda potencialmente muito grande por próteses robóticas de membro inferior, mas que encontram grandes dificuldades em se realizarem por conta do preço e da visão das pessoas a respeito do uso de próteses robóticas. Entretanto, com o trabalho de uma equipe multiprofissional que inclua engenheiros, médicos, protesistas, fisioterapeutas e até mesmo psicólogos, é possível a criação de um dispositivo robótico de menor custo, adaptado à realidade brasileira, além de todo um sistema mais amigável ao usuário, com o desenvolvimento não só da prótese em si, mas todo um conjunto de medidas visando o pleno uso da prótese pelo usuário.

Portanto, a construção de tal dispositivo robótico é o objetivo deste trabalho. 


\subsection{Breve histórico do projeto}

O presente trabalho foi concebido no âmbito da linha de pesquisa em tecnologia assistiva conduzida pelos professores Geovany Araújo Borges e Antônio Padilha Lanari Bó, além de um extenso grupo de trabalho, do Laboratório de Automação e Robótica do Departamento de Engenharia Elétrica da Universidade de Brasília. Desde o ano de 2005, uma extensa série de trabalhos foram produzidos e publicados $[9,10,11,12,13,14,15,16,17,18,19,20,21,22,23,24,25,26,27,28,29,30]$ pelos pesquisadores membros do grupo de trabalho para o desenvolvimento de uma prótese robótica transfemural.

Em 2010 tem início o projeto de pesquisa Tecnologias Avançadas de Próteses para Amputados de Membro Inferior, com recursos da Financiadora de Estudos e Projetos - FINEP -, a partir do qual foram construídos diversos protótipos nos quais foram estudados os variados aspectos envolvidos no desenvolvimento de próteses robóticas de membro inferior como sistemas de atuação, sistemas de controle e estratégias de medição de variáveis proprioceptivas e exteroceptivas. A figura 1.2 mostra a evolução dos protótipos de bancada desenvolvidos para a avaliação desses referidos aspectos.
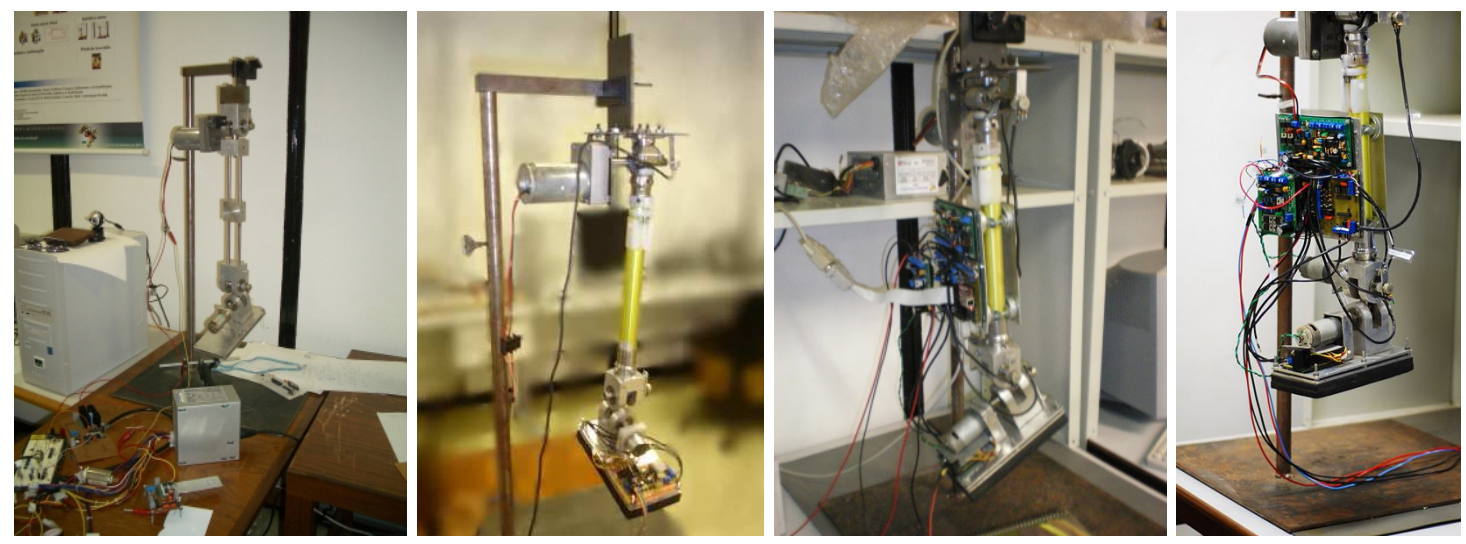

Figura 1.2: Evolução dos protótipos de bancada produzidos no âmbito dos projetos de pesquisa em tecnologia assistiva $(2005-2010)$.

\subsection{Resultados obtidos}

O principal resultado apresentado pelo presente trabalho é a construção de um protótipo funcional de prótese transfemural robótica. O joelho protético foi fabricado como um mecanismo de quatro barras funcionando como uma junta policêntrica. O acionamento mecanismo do joelho é feito por um atuador magneto-reológico em formato pistão. O sistema embarcado da prótese é capaz de detectar eventos de marcha por meio da processamento das leituras do sensores instalados na prótese. Os resultados apresentados são validados através de simulações computacionais e experimentos feitos com o auxílio de um amputado transfemural voluntário e parceiro do projeto. A figura 1.3 exibe o a prótese completa.

O dispositivo projetado é capaz de se movimentar de maneira similar ao joelho natural, carac- 


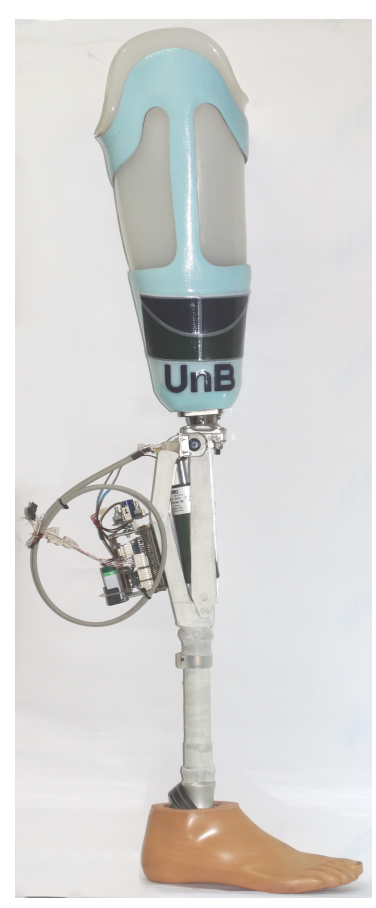

Figura 1.3: Protótipo funcional de prótese transfemural.

terística dada pelo mecanismo policêntrico de quatro barras, visto que a anatomia joelho humano em marcha pode ser considerada também um mecanismo de quatro barras [31].

O posicionamento do centro de rotação do joelho protético, que não é fixo mas varia percorrendo uma trajetória bem definida, confere maior estabilidade nas fases de suporte da marcha e a movimentação das peças componentes do mecanismo durante a marcha gera uma diminuição do comprimento total da perna protética nas fases de balanço da marcha.

A estratégia de atução utilizada se mostra capaz de promover marcha de maneira comfortável ao usuário, além de promover esforços compatíveis com os esforços requeridos do joelho em marcha.

O presente trabalho resultou em três artigo apresentados em dois congressos internacionais com a temática de robótica biomédica - 5th IEEE RAS \& EMBS International Conference on Biomedical Robotics and Biomechatronics (BioRob 2014) e 5th IEEE Biosignals and Biorobotics Conference (BRC 2014) - e um nacional - XI SBA Simpósio Brasileiro de Automação Inteligente (SBAI 2013) $-^{3}$.

\subsection{Apresentação do manuscrito}

O capítulo 2 apresenta a base teórica necessária ao entendimento dos assuntos relativos ao projeto e construção de uma prótese transfemural robótica. O capítulo inicia introduzindo conceito de marcha humana e os assuntos relativos à mesma dos pontos de vista funcional e biomcânico, onde são analisados diversos gráficos de variáveis da marcha humana e seu relacionamento com as

\footnotetext{
${ }^{3}$ IEEE: Institute of Electrical and Electronics Engineers; IEEE RAS: IEEE Robotics and Automation Society; IEEE EMBS: IEEE Engineering in Medicine and Biology Society; SBA: Sociedade Brasileira de Automática
} 
tarefas mecânica envolvida na marcha. Em seguida é vista uma contextualização a respeito dos aspectos gerais de próteses de membro inferior, apresentando os componentes básicos das mesmas e discutidas as vantagens e desvantagens das alternativas mecânicas para próteses. Por fim, neste capítulo, apresentamos com maior detalhe aspectos relevantes ao projeto de próteses robóticas, seus sistemas embarcados, sensores e atuadores - com destaque ao atuadore utilizado neste projeto.

O capítulo 3 descreve todo o processo de desenvolvimento da prótese. Inicialmente são definidos os requisitos de projeto impostos sobre a prótese e os aspectos chave da mesma. Então passamos a um estudo mais aprofundado sobre o mecanismo adotado para o joelho da prótese e estabelecemos o equacionamento utilizado para o cálculo das principais características do mecanismo. Em seguida detalhamos a modelagem mecânica do joelho protético, apresentando as simulações numéricas e os modelos CAD do mesmo. Fazemos então, a verificação dos requisitos sobre o modelo pronto, suas dimensões e movimentação. Sobre o modelo executamos simulações para verificação da sua integridade estrutural sob a ação de esforços compatíveis com os presentes na marcha. Verificada a adequação estrutural do modelo, passamos à descrição do protótipo físico do joelho propriamente dito: suas dimensões, ajustes, montagem, acoplamento do atuador, encaixe na estrutura protética completa e as características funcionais vantajosas advindas desse tipo de mecanismo. As últimas duas sessões desse capítulo trazem detalhamentos do atuador utilizado para o acionamento do joelho protético e dos sensores e sistema embarcado da prótese.

A avalição experimental do dispositivo é apresentada no capítulo 4. Primeiramente o dispositivo é avaliado com o voluntário amputado assim que confeccionado e montado juntamente com atuador e os outros componentes da estrutura básica da prótese em modo passivo. Então mostramos um segundo experimento em modo montrole manual, no qual um operador controla manualmente a referência de corrente elétrica aplicada ao pistão. Por fim, esse capítulo mostra um experimento com a prótese em modo de identificação - funcionando somente com a captura dos sinais dos sensores e com o atuador desligado - e com sistema de captura de movimento óptico de captura de movimento.

Por fim o capítulo 5 traz as conclusões do trabalho bem como as perspectivas de trabalhos futuros do projeto. 


\section{Capítulo 2}

\section{Fundamentação teórica}

\subsection{Marcha humana}

"Marcha ou deambulacão é um tipo de locomoção de padrão bípede gerado pelo sistema sensório-motor" [32]. Esta é uma definição dentre as mais aceitas para essa tarefa funcional humana e, a partir dela, é importante que se entenda que o que chamamos marcha abarca todas as formas de locomoção bípede, ou seja, andar, correr, subir escadas, saltar, são diferentes modos de marcha. Grande parte dessas atividades envolve um padrão periódico chamado ciclo de marcha, que compreende uma passada completa, no caso do andar [33]. Isso significa que, de modo geral, a cada passada repetem-se os mesmos movimentos de forma que a evolução do movimento como um todo pode ser considerada previsível. Além disso, é notável a simetria lateral da marcha. De fato, o movimento executado por um dos membros inferiores em um passo será igualmente executado pelo outro membro com uma diferença de fase. Essa é mais uma característica de previsibilidade.

Em se tratando do andar humano, o ciclo de marcha é caracterizado por duas fases distintas funcionalmente, a saber o suporte e o balanço, cada qual composta de uma seqüência de eventos bem definidos - sub-fases - que indicam o estado do ciclo de marcha [5]. A figura 2.1 mostra um diagrama com as fases e os eventos caracterizantes da marcha vistos em seqüência.

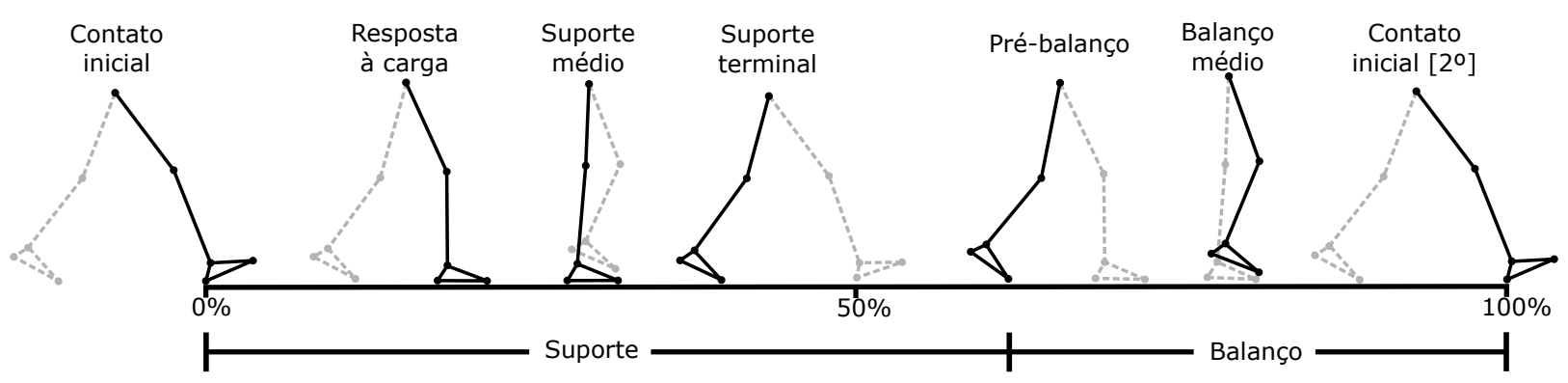

Figura 2.1: Ciclo de marcha com suas fases e eventos característicos.

Na figura 2.1 vemos um esquema representando os membros inferiores em marcha com seus eventos característicos descritos abaixo. 
1. Contato inicial: destacado pelo instante em que o calcanhar toca o solo (HS);

2. Resposta à carga: representado pelo momento em que o pé se aplaina com a superfície (FF);

3. Apoio médio: que ocorre quando o peso do indivíduo se descarrega totalmente sobre uma das pernas (SL);

4. Apoio terminal: instante em que o calcanhar deixa o solo (HO);

5. Pré-balanço: instante da máxima impulsão com desprendimentos dos dedos do solo (TO);

6. Balanço: período em que a perna está livre de carga (MS).

Finalizando com o contato inicial da nova passada reiniciando o ciclo ${ }^{1}$.

Fica notável a partir da figura 2.1 a simetria lateral citada anteriormente quando observamos por exemplo a correspondência entre o evento de contato inicial e evento de pré-balanço nos quais as duas pernas executam os mesmos movimentos de maneira alternada.

\subsubsection{Biomecânica da marcha}

A marcha é caracterizada por um padrão repetitivo de ativação dos músculos esqueléticos para movimentar o corpo em alguma direção enquanto o mantém estável em equilíbrio dinâmico. Todos os grupos musculares do corpo, em maior ou menor escala, atuam para perfazer esses dois objetivos simultaneamente - movimento direcional e equilibrio -, em especial os grupos musculares localizados no membro inferior. Em se tratando do andar, no intuito de cumprir esses objetivos, o sistema musculoesquelético trabalha para cumprir três grandes tarefas biomecânicas durante as fases da marcha: recepção do peso, suporte simples e avanço do membro[33]. A figura 2.2 mostra o relacionamento entre as fases, as tarefas e as sub-fases.

A recepção do peso é a tarefa na qual o peso vai sendo gradualmente transferido para o membro mais avançado desde o contato inicial até o momento exatemente anterior o decolamento do membro mais atrasado do solo. No momento em que peso é totalmente transferido temos o início do suporte simples que avança até o pré-balanço. Durante o pré-balanço quando o membro que até então está suportando totalmente o peso começa seu descolamento do solo o outro membro toca o solo e a marcha entra rapidamente em suporte duplo. Em seguida o membro que se descola do solo entra em balanço passando por um avanço em sua posição. Para melhor entendimento de como membro inferior se comporta em termos biomecânicos para cumprir essas tarefas, passaremos à análise das articulações do joelho e do tornozelo.

\subsubsection{Biomecânica do joelho}

O joelho é uma articulação complexa situada na junção da extremidade distal do fêmur com a extremidade proximal da tíbia, onde também se localiza a patela. Além desses ossos, existem diver-

\footnotetext{
${ }^{1}$ A literatura consagrou as siglas em inglês para a nomenclatura dos eventos da marcha: heel strike (HS), foot flat $(\mathrm{FF})$, single leg support (SL), heel off (HO), toe off (TO) e mid-swing (MS).
} 


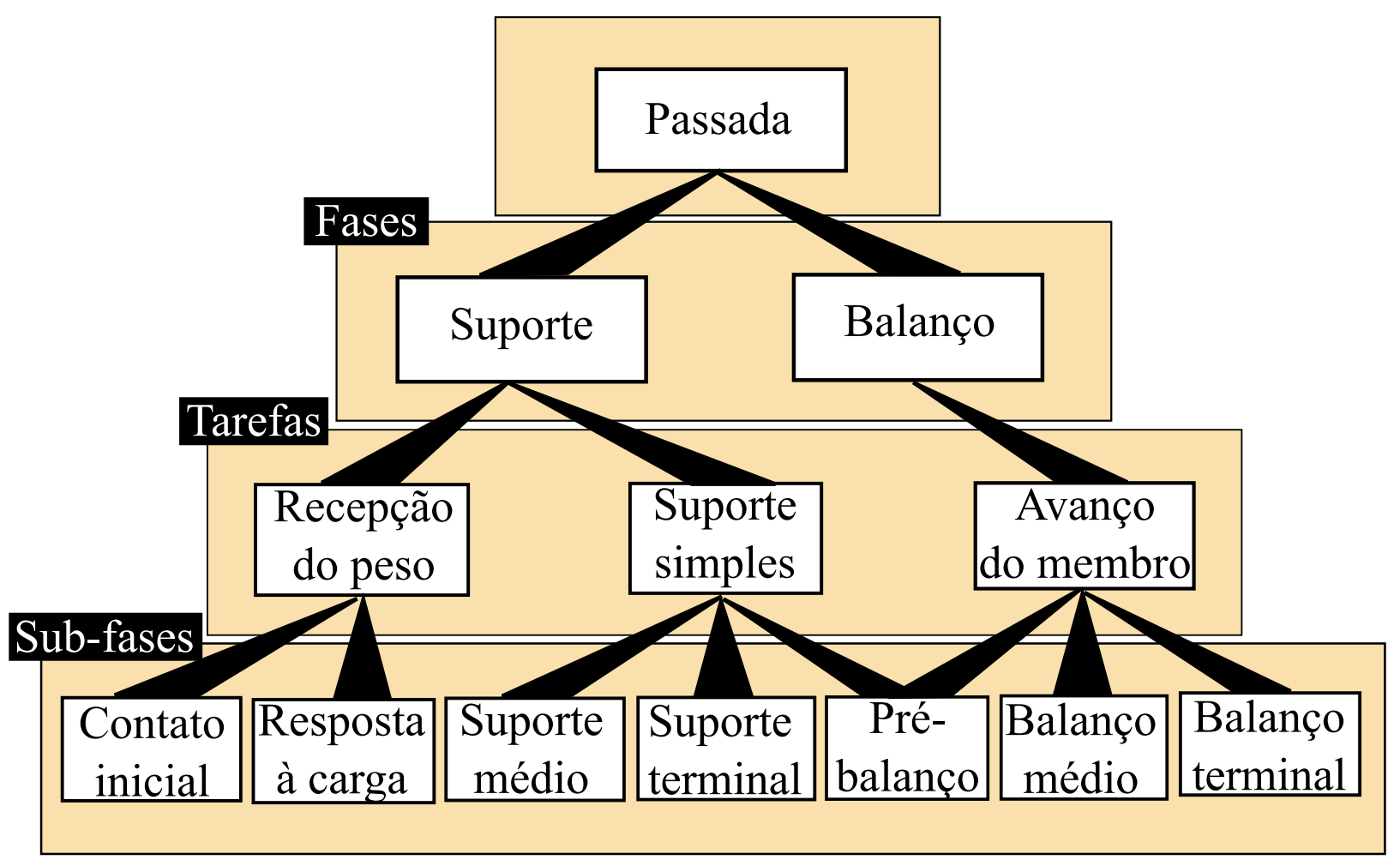

Figura 2.2: Divisões do ciclo de marcha.

sos ligamentos e músculos atuando nessa articulação. Os ligamentos têm a função de estabililizar e definir a cinemática da articulação. O músculos são os atuadores das juntas, eles fornecem o torque para a movimentação. Assim como a maioria das articulações do corpo humano, os músculos que atuam no joelho tem um comportamento antagonista, ou seja, para cada plano de movimentação da articulação dois grupos de músculos trabalham em oposição mover o membro em uma direção ou na direção oposta. No que se refere a movimentação do joelho no plano sagital os dois grupos trabalham para extender ou flexionar o joelho. Durante um ciclo de marcha, o joelho tem sua variação angular e os torques motores específicos ${ }^{2}$. As figuras 2.3 e 2.4 ilustram trajetórias típicas para tais variáveis.

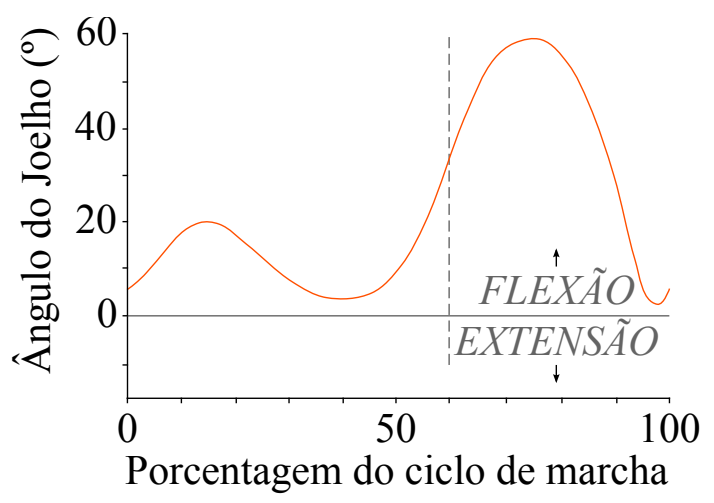

Figura 2.3: Variação angular do joelho durante um ciclo de marcha. Adaptado de [5]

\footnotetext{
${ }^{2}$ Torque normalizado por unidade de massa.
} 


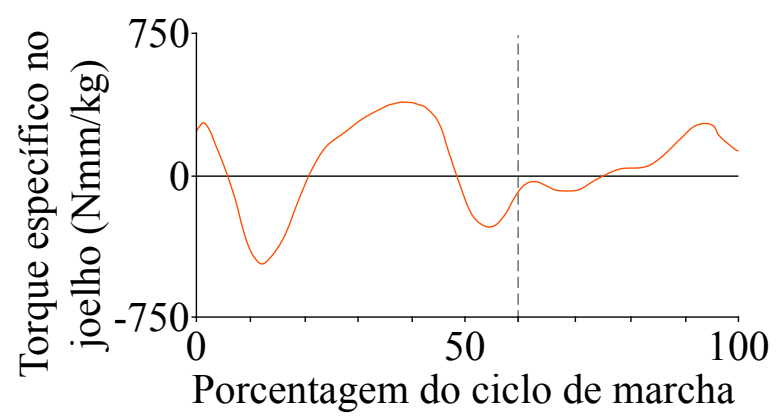

Figura 2.4: Torque por unidade de massa no joelho durante um ciclo de marcha. Adaptado de [5]

As figuras, seguindo os padrões utilizados na literatura de biomecânica [33][5], adotam o valor de zero grau para o joelho totalmente estendido e o movimento de flexão como sentido positivo do movimento. Podemos ver na figura 2.3 destacadamente dois movimentos de flexão: um de magnitude reduzida - aproximadamente $20^{\circ}$ - durante a fase de suporte e outro de maior magnitude - aproximadamente $60^{\circ}$ - durante o balanço, intercalados por momentos de extensão quase completa.

Analisando concomitantemente as figuras 2.1, 2.3 e 2.4 vemos que essa flexão durante o suporte está relacionada com a recepção do peso do corpo pelo membro com um joelho moderadamente flexionado e um acentuado esforço extensor. Subseqüentemente, podemos ver um pronunciado esforço flexor enquanto o membro tende a se extender também em relacionamento com a recepção do peso. Esses dois movimentos aumentam a rigidez do membro de maneira gradual, recepcionando o peso do corpo preparando o membro para entrar em suporte simples, quando ele suportará todo o peso.

A análise dessas três figuras permite perceber também que o período de maior flexão, entre 60 e $85 \%$ do ciclo de marcha, correspondente ao balanço, ocorre à torques muito baixos. Isso sugere fortemente que essa flexão se deve principalmente à inércia da perna, que não está sujeita à grandes torques durante as primeiras etapas do avanço do membro.

Seguindo de um período de torques muito baixos, o período final do avanço do membro, entre 90 e $100 \%$ do ciclo de marcha, é marcado por um visível torque resistivo ao movimento de extensão por qual passa o joelho, o que pode ser visto nas figuras 2.3 e 2.8. Nesse momento o membro está se preparando para entrar novamente em contato com a superfície e recepcionar o peso, se fazendo necessário que o joelho novamente aumente sua rigidez para o início de um novo ciclo.

As figuras 2.5 e 2.6 mostram respectivamente um gráfico de potência específica ${ }^{3}$ no joelho e um diagrama de ativação muscular através do sinal eletromiográfico (EMG) dos músculos bíceps femural e dos vasti.

\footnotetext{
${ }^{3}$ Potência normalizada por unidade de massa
} 


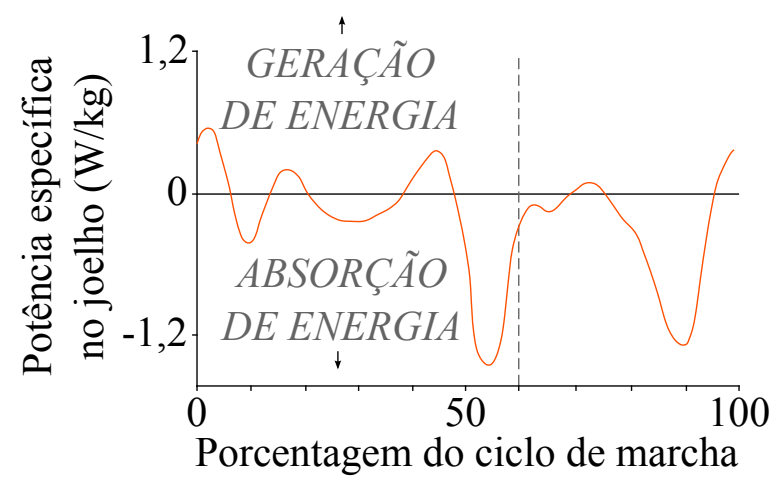

Figura 2.5: Potência por unidade de massa no joelho durante um ciclo de marcha. Adaptado de $[5]$

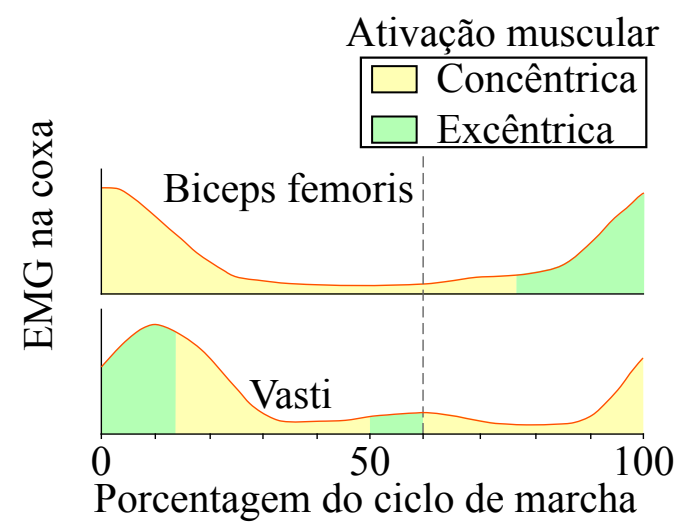

Figura 2.6: Sinal de EMG de músculos da coxa: biceps femoris (flexor do joelho) e vasti (conjunto de extensores do joelho). Adaptado de [5]

A partir do gráfico da figura 2.5, fica bastante perceptível que a potência desenvolvida pelos torques atuantes no joelho são em sua maior parte de natureza passiva, ou seja, atuam de maneira reativa ou resistiva ao movimento. Isso significa que, muito mais do que inserir potência ativa no movimento, o joelho age no sentido de absorver e devolver parcialmente ao movimento uma fração da potência dissipada no movimento. Ao chocar o pé com o solo ou ao deslocar o centro de massa para cima e para baixo, o corpo dissipa uma certa quantidade de energia através da flexão amortecida do joelho que acontece durante a recepção do peso. O aumento gradual da rigidez no joelho favorece o comportamento reativo e uma parte da energia dissipada é armazenada no tensionamento dos tendões e músculos, para ser então regenerada ao movimento.

O diagrama da figura 2.6 corrobora com essa interpretação. Desde o início até aproximadamente $14 \%$ do ciclo de marcha, tanto o bíceps femural quanto os vasti estão em alto nível de ativação concêntrica e excêntrica, respectivamente ${ }^{4}$. Os dois grupos antagonistas - flexores e extensores do joelho - estão sendo ativados ao mesmo tempo, acarretando no aumento da rigidez no joelho. O mesmo acontece no final do ciclo de marcha, porém os músculos invertem seus papéis, os flexores

\footnotetext{
${ }^{4}$ Ativações musculares concêntrica e excêntrica são, respectivamente, aquelas que ocorrem a favor e contra o sentido da contração.
} 
entram em ativação excêntrica e os extensores, concêntrica.

Ainda no mesmo diagrama é possível notar uma fraca, porém crescente, ativação excêntrica dos vasti entre 50 e $60 \%$ do ciclo. Essa ativação ocorre no momento extamente anterior ao descolamento do pé do solo em decorrência do início do movimento de flexão para o balanço. O joelho está no início da flexão, porém o pé ainda está em contato com o solo, sendo, então, necessário um esforço muscular para modular essa flexão e impedir que essa seja exagerada.

\subsubsection{Biomecânica do tornozelo}

A articulação do tornozelo, situada na junção das extremidades distais da tíbia e da fíbula com o talus, é composta além desses ossos também de ligamentos e músculos que, assim como no joelho, tem atuação antagonista. No caso do tornozelo em movimentação no plano sagital, os grupos antagonistas trabalham para realizar os movimentos de plantarflexão e dorsiflexão, considerando como sentido positivo do movimento o sentido da dorsiflexão a partir da posição neutra na qual a tíbia faz um ângulo de noventa graus com o plano plantar. Durante um ciclo de marcha, o tornozelo tem sua variação angular e os torques motores específicos mostrados nas figuras 2.7 e 2.8 .

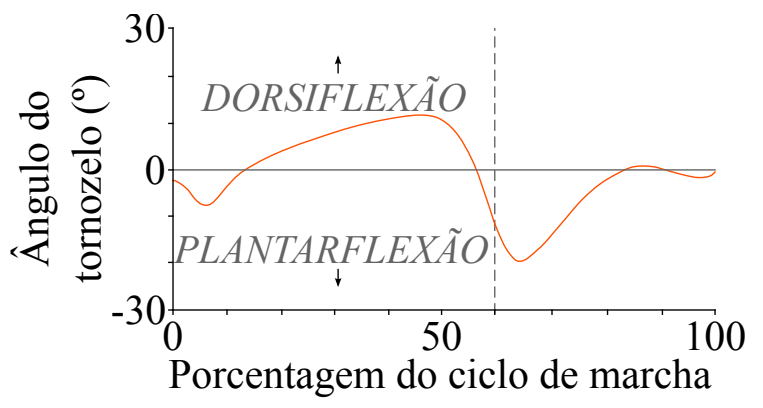

Figura 2.7: Variação angular do tornozelo durante um ciclo de marcha. Adaptado de [5]

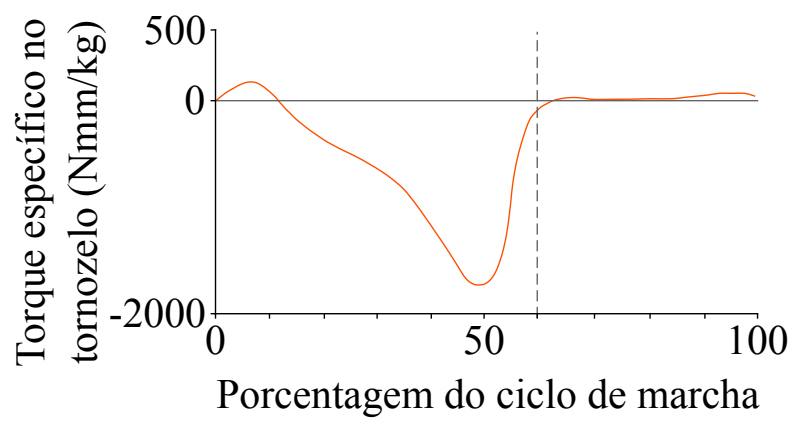

Figura 2.8: Torque por unidade de massa no tornozelo durante um ciclo de marcha. Adaptado de $[5]$

Na figura 2.7 é posssível ver logo no início do ciclo de marcha - aproximadamente $7 \%$ - uma pequena plantarflexão em torno de $8^{\circ}$. Vemos também que a variação angular total é de aproximadamente $32^{\circ}$, sendo $20^{\circ}$ em máxima plantarflexão e $12^{\circ}$ em máxima dorsiflexão, que ocorrem 
a aproximadamente 46 e $64 \%$ do ciclo, respectivamente. Analisando essa figura em conjunto com a figura 2.8, percebemos na plantarflexão logo no início do ciclo ocorre simultaneamente com um leve esforço de dorsiflexão. Isso ocorre para que a tarefa de recepção do peso ocorra com o menor impacto possível. Então o pé vai aceitando o impacto enquanto cede a plantarflexão até que o pé se aplaine com o solo.

Podemos também perceber que o elevado esforço plantarflexor - ocorrendo a aproximadamente $50 \%$ do ciclo - está associado ao instante de máxima dorsiflexão, evidenciando um esforço propulsor no sentido do movimento do corpo. Isso acontece de maneira coerente com as tarefas que o corpo está executando nesse instante, enquanto o membro finaliza a tarefa de suporte simples ele propulsiona o corpo transferindo o peso para o outro membro que está executando a tarefa de recepcionar o peso.

Logo após à maxima dorsiflexão ocorre um acentuado movimento de plantarflexão acompanhado de uma queda quase total do esforço no momento exatamente anterior ao descolamento do pé do solo. Nesse momento o peso já foi quase todo transferido para o outro membro e o membro em destaque está entrando em balanço.

Entre os 60 até aproximadamente $64 \%$ do ciclo, o tornozelo continua realizando plantarflexão, porém a torques desprezíveis, ou seja, um movimento puramente decorrente da inércia do pé. Esse torque permanece em níveis muito baixos até o final do ciclo enquanto o tornozelo dorsiflexiona gradativamente até aproximadamente $80 \%$ do ciclo. Nesse instante, ele atinge uma posição neutra e permanece assim com variações pequenas até o final do ciclo.

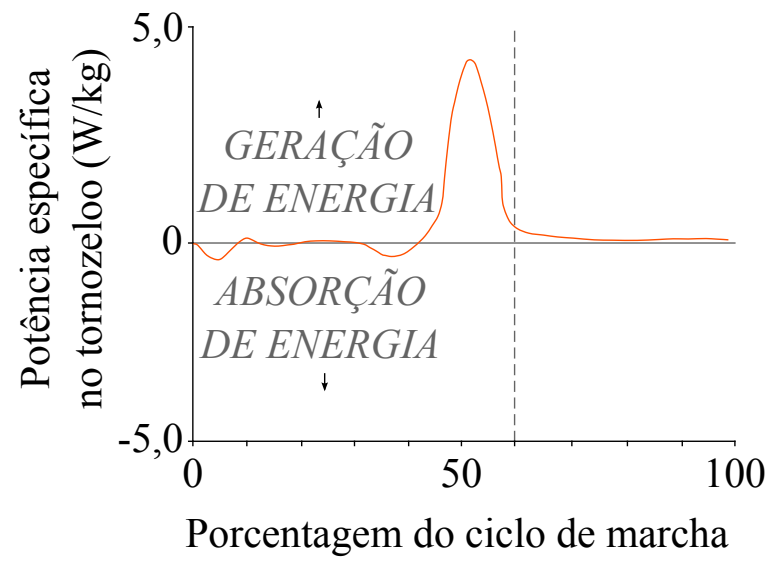

Figura 2.9: Potência por unidade de massa no tornozelo durante um ciclo de marcha. Adaptado de [5] 


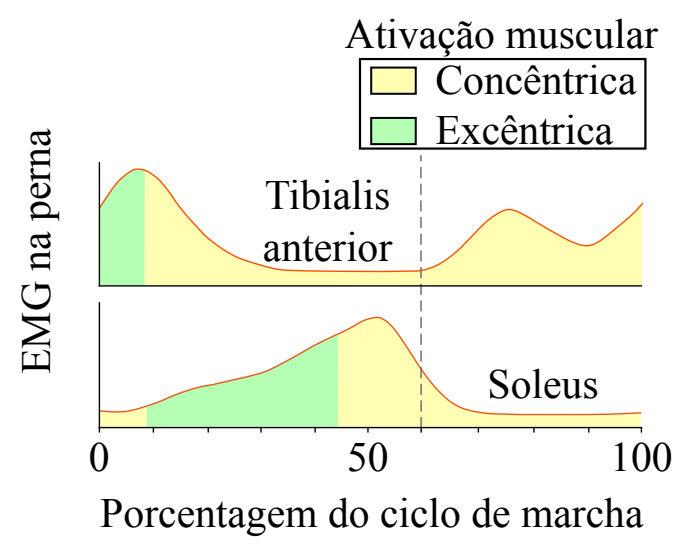

Figura 2.10: Sinal de EMG de músculos da perna: tibialis anterior (dorsiflexor) e soleus (plantarflexor). Adaptado de [5]

Como é possível ver na figura 2.9, que traz um gráfico de potência específica no tornozelo, existe um grande pico de geração de energia à aproximadamente $50 \%$ do ciclo. Isso ocorre em total concordância com o esforço de propulsão citado. Toda a geração de energia no tornozelo é concentrada nesse instante para fazer a transferência do peso de um membro para o outro. Além disso vemos uma pequena absorção de energia entre 0 e $50 \%$ do ciclo, também em concordância com tarefa de recepção do peso.

A ativação muscular exibida no diagrama da figura 2.10, vem ao encontro das análises feitas para o tornozelo até esse ponto. Inicialmente o músculo tibial anterior, representando o grupo dorsiflexor, está em alto nível de ativação modulando a absorção do impacto no pé, para execução da tarefa de recepção do peso enquanto o músculo sóleo, representando o grupo plantarflexor, permanece pouco ativado. Em seguida o sóleo entra em forte e gradual ativação excêntrica, tracionando os tendões responsáveis pela plantarflexão, até a máxima dorsiflexão. O nível de ativação do sóleo permanece aumentando, agora de maneira concêntrica, até o descolamento do pé com o solo. Nesse momento, o nível de ativação cai rapidamente e permanece em níveis muito baixos até o final do ciclo, enquanto o tibial anterior trabalha para trazer o pé em balanço - livre de cargas externas - para a posição neutra, preparando-o para novamente recepcionar o peso no novo ciclo.

\subsection{Aspectos gerais de próteses de membro inferior}

Próteses de membro inferior são concebidas para substituir o membro amputado de indivíduos com amputação e, assim, promover marcha. O nível da amputação define o tipo de prótese a ser utilizada. Assim, para uma amputação na altura da perna ${ }^{5}$ utiliza-se uma prótese transtibial. Já para uma amputação no nível da coxa é utilizada uma prótese transfemural. Nesse trabalho daremos atenção especial às próteses transfemurais.

São diversos os aspectos relevantes quando falamos em protetização de amputados de membro

\footnotetext{
${ }^{5}$ Em geral, o termo perna é utilizado erroneamente para designar todo o membro inferior. Perna é a parte do membro inferior que compreende a região entre o joelho e o tornozelo.
} 
inferior. Nível de atividade do indivíduo, altura da amputação, características corporais - peso, altura, geometria do coto de amputação -, segurança, controle da prótese, conforto, estética do dispositivo, peso da prótese, geometria e dimensões da protése, estão entre esse aspectos. No que se refere a próteses ativas, alvo deste trabalho, outros fatores são adicionados, principalmente, a potência dos atuadores da prótese, a autonomia energética, os algoritmos de controle do dipositivo e a adaptabilidade recíproca entre indivíduo e prótese[34].

No caso de indivíduos com amputações tranfemurais requer-se de uma prótese que garanta condições para que o índividuo seja capaz de se locomover com segurança, exercendo esforços compatíveis com a intensidade da marcha, com o mínimo desconforto e cosmeticamente aceitável pelo usuário. A intensidade do esforço que o usuário exercerá para se locomover depende diretamente do alinhamento dos componentes da prótese transfemural. Como pode ser visto em [35] um alinhamento equivocado pode provocar aumento de $13 \%$ no consumo de energia pelo usuário. Da mesma maneira um sistema inadequado de suspensão pode trazer riscos de falhas de segurança, como a soltura da prótese, além de aumentar o esforço promovido pelo usuário da prótese.

\subsubsection{Componentes básicos de próteses de membro inferior}

Levando em consideração os aspectos mencionados, tipicamente uma prótese transfemural se constitui de quatro componentes principais: o soquete ou outro sistema de suspensão, o joelho, a canela (também chamada extensor de tíbia) e o conjunto tornozelo-pé. A figura 2.11 mostra uma prótese transfemural típica evidenciando seus componentes principais.

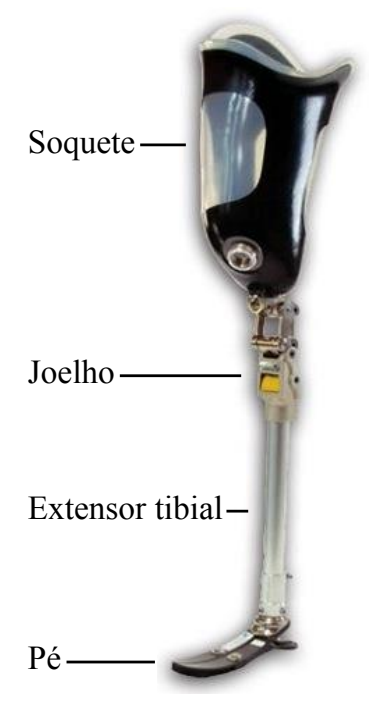

Figura 2.11: Prótese transfemural típica, com destaque aos quatro elementos principais que a compõe.

O soquete é o componente responsável pela conexão entre usuário e prótese, realizando as transferências de forças e torques. São fabricados em material rígido, normalmente resina acrílica, ou mesmo em material flexível à base de silicone e com reforço estrutural em fibra de vidro ou resina. Ele deve ser finamente ajustado ao usuário de forma que haja distribuição uniforme de pressão 
e elimine-se o esforço cisalhante [36]. Um soquete mal ajustado, em geral, acaba concentrando forças em determinadas regiões do membro residual do usuário da prótese e, conseqüentemente, levando a sérias lesões. Em [36] é possível ver com mais detalhe como um soquete mal ajustado pode causar problemas graves à saúde do usuário.

No intuito de atingir esse fino ajuste, diversos equipamentos e materiais são utilizados, desde meias especiais confeccionadas para uso em cotos de amputação, que ajudam a suavizar o contato entre o coto e o soquete, até os adaptadores conhecidos como liners e as válvulas de sucção. O liner é um equipamento que se assemelha a uma meia em sua forma, mas são feitos em silicone e revestidos de uma fina camada têxtil. Ele se molda perfeitamente ao coto impedindo a formação de bolhas de ar e distribuindo melhor os esforços, o que torna o contato com o soquete mais consistente e comfortável. As válvulas de sucção são praticamente onipresentes nos soquetes, elas permitem a passagem de ar somente de dentro para fora do soquete de forma que quando o usuário calça o soquete forma-se um vácuo em seu interior aumentando a firmeza do encaixe.

A canela é o componente estrutural de ligação entre o joelho e o conjunto tornozelo-pé e consiste de uma barra rígida, normalmente tubular, feita em material leve. Assim como o soquete essa é uma peça ajustada para cada usuário em comprimento e alinhamento. Novamente, um ajuste inadequado pode implicar em riscos à saúde do usuário, como problemas na bacia e na coluna decorrentes do padrão patológico da marcha do usuário.

As duas próximas seções são dedicadas a um detalhamento dos outros dois componentes básicos de próteses transfemurais: o joelho protético e o conjunto tornozelo-pé.

\subsubsection{Joelho protético}

São encontrados no mercado uma grande diversidade de modelos de joelho protético que são classificados, principalmente, pelo nível de serviço - em termos de conforto, segurança, variabilidade de movimentos, leveza, entre outros - que eles oferecem ao usuário. Desde os joelhos construídos como um simples mancal rotativo até mecanismos complexos compostos de diversos elementos mecânicos passivos e/ou ativos que conferem maior conforto e segurança à marcha do usuário.

Do ponto de vista cinemático, eles podem ser separados em dois grandes grupos: joelhos monocêntricos e joelhos policêntricos. O primeiro, consiste de uma junta rotativa simples no qual existe um centro de rotação fixo entre os eixos axiais do fêmur e do extensor tibial. O segundo, alternativamente, consiste de um dispositivo que combina movimentos rotativos e translacionais de forma que o centro de rotação não é fixo. Surge então um centro instantâneo de rotação (CIR) que varia de acordo com o ângulo entre os eixos axiais do fêmur e dos extensor tibial em uma trajetória bem definida. A figura 2.12 exibe dois joelhos protéticos comerciais, o primeiro monocêntrico e o segundo policêntrico, para exemplificar esses dois grupos. 


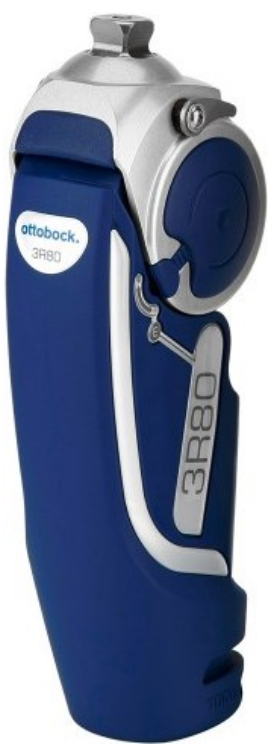

(a)

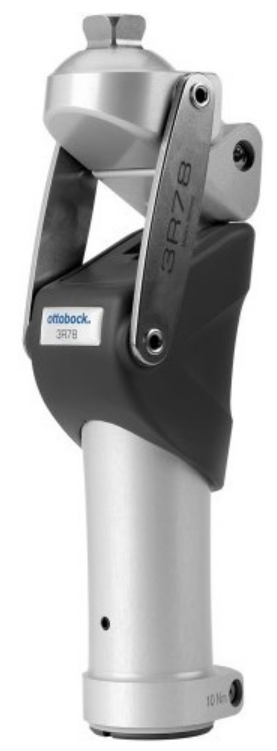

(b)

Figura 2.12: Dois modelos de joelhos protéticos comerciais fabricados pela Ottobock ${ }^{\circledR}$, Alemanha: (a) Joelho monocêntrico $3 R 80$; (b) Joelho policêntrico $3 R 78$

Certamente, os joelhos monocêntricos são os mais encontrados no mercado dadas sua simplicidade e mais fácil adaptabilidade pelo usuário, o que também se traduz em maior acessibilidade, incusive financeira, para o usuário, entretanto o arranjo policêntrico apresenta uma série de vantagens mecânicas funcionais bastante desejáveis para quaquer usuário de prótese transfemural. A primeira vantagem é a similaridade cinemática desse arranjo com um joelho humano natural que também é uma junta policêntrica. Tal similaridade confere simetria cinemática durante a marcha, ou seja, a marcha realizada pelo usuário é muito mais próxima à natural.

Uma segunda vantagem é a possibilidade de se posicionar o CIR de forma conveniente em determinadas fases da marcha. Avaliando a movimentação no plano sagital, é possível ver no caso do joelho humano, que durante a fase de suporte CIR está posicionado posteriormente à linha de carga - linha na direção da gravidade passando pelo centro de massa do corpo - do indivíduo. Dessa forma, o peso do indivíduo tende a hiperextender o joelho, movimento impedido mecanicamente pelo posicionamento do fêmur, da tíbia e dos ligamentos do joelho. Isso resulta em uma grande economia de energia para o indivíduo, já que o esforço muscular é bastante reduzido nessa situação. A figura 2.13 mostra um desenho exemplificando a situação. Nela é possível ver que enquanto o peso - representado pela linha de carga em amarelo do indivíduo - provoca um esforço no sentido da hiperextensão do joelho os arcos em vermelho mostram o sentidos dos torques em reação ao efeito da carga. 


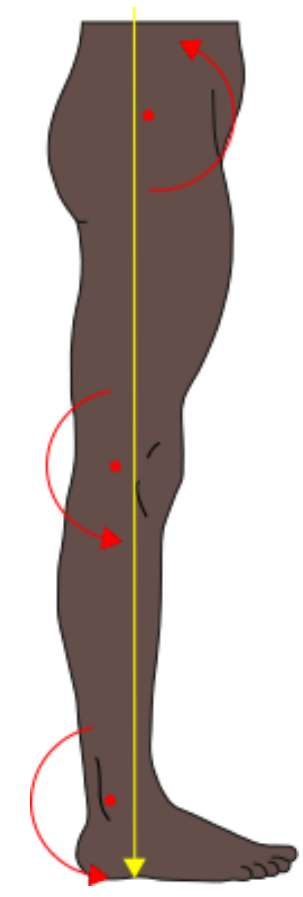

Figura 2.13: Travamento do joelho em extensão total durante o suporte. A linha amarela representa a linha de carga do indivíduo e a os arcos vermelhos com seus respectivos centros mostram os sentidos dos torques de reação aplicados pelos tendões nas juntas do quadril, joelho e tronozelo. Adaptado de [37]

Por fim, uma terceira vantagem observável em um joelho policêntrico é a mudança no comprimento total do mecanismo em decorrência da característica translacional que este apresenta. Essa alteração no comprimento, que em geral trata-se de um encurtamento, é desejável na fase de balanço, pois ela ocasiona um maior distanciamento entre o pé e a superfície, evitando assim que o pé se choque com a superfície.

\subsubsection{Conjunto tornozelo-pé}

Assim como o joelho, o conjunto tornozelo-pé protético é o equivalente ao tornozelo e ao pé humanos e, portanto, deve possuir similaridade funcional. Utilizado tanto em próteses transfemurais quanto em próteses transtibiais, ele é importante elemento de estabilização e absorção de impacto durante a marcha, mas sobretudo ele deve ser o principal elemento de inserção de potência ativa e reativa. Como podemos ver em [38] o tornozelo e o pé humanos saudáveis, são os principais responsáveis por essas tarefas, executando torques que chegam ao pico de $80 \%$ do trabalho mecânico total do membro inferior durante a marcha.

Quanto ao tornozelo, o que mais comumente se vê no mercado são tornozelos rígidos, ou seja, sem nenhuma articulação que permita motilidade nessa junta[39]. Do ponto de vista da segurança funcional ao usuário de um tornozelo assim, essa é uma configuração bastante conservadora. Por um lado ela oferece ao usuário mais firmeza para executar movimentos mais simples, porém, por outro lado, limita bastante a quantidade e a qualidade - em termos de economia energética, mobilidade 
e flexibilidade - de movimentos que o usuário é capaz de executar.

Uma alternativa a esses modelos rígidos são os tornozelos articulados com um grau de liberdade para movimentação no plano sagital ${ }^{6}$. Essa articulação permite que se insira na junta dispositivos capazes de amortecer os esforços, armazenar e regenerar energia e até mesmo gerar esforço motor, além de aumentar a amplitude de movimento da junta[39].

Em relação ao pé protético, os modelo mais comuns no mercado são confeccionados em materiais que permitem alguma flexibilidade à nível plantar como o pé SACH (acrônimo de Solid Ankle Cushioned Heel) e os pés de fibra de carbono. Estes últimos são confeccionados em modelos variados com maior flexibilidade de movimentos - inclusive no plano frontal - permitindo mais estabilidade e robustez à marcha[39]. A figura 2.14 mostra exemplos de tornozelos fixos e articulados e modelos mais comuns de pés protéticos.

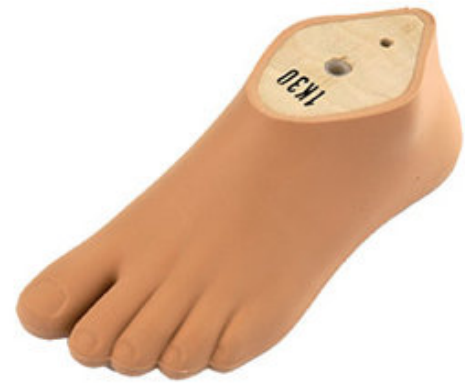

(a)

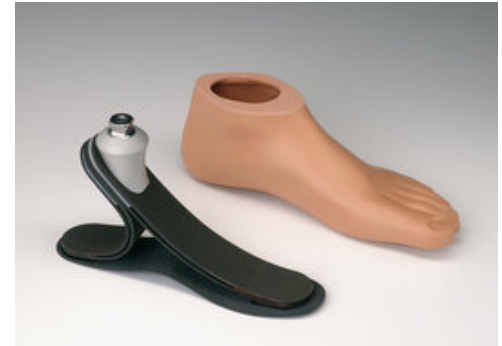

(b)

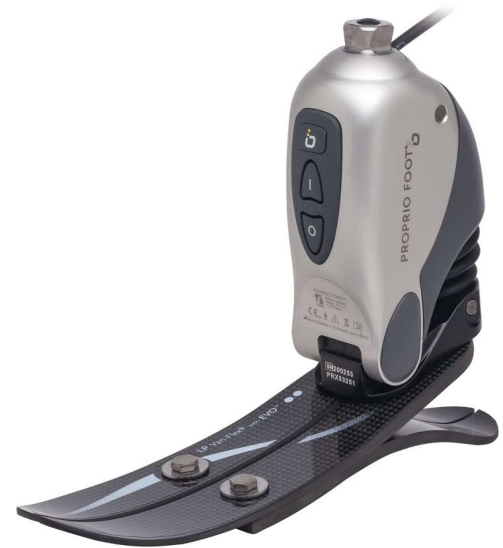

(c)

Figura 2.14: Exemplos pés protéticos. (a) Pé SACH 1K30 da Ottobock; (b) Pé de carbono 1C30 Trias da Ottobock; (c) Pé robótico com tornozelo articulado Proprio Foot da Össur.

\subsubsection{Próteses transfemurais passivas}

As próteses passivas são aquelas que não possuem nenhum componente capaz inserir energia mecânica no marcha, tais como motores. Ou seja, toda a energia envolvida no movimento é proveniente dos esforços do próprio usuário. Como apresentado na seção 2.1, os músculos são os elementos responsáveis por essa inserção de energia. No indivíduo amputado grande parte desses músculos envolvidos com a marcha são perdidos e, no caso do amputado ser usuário de uma prótese passiva, os outros músculos se encarregam dos esforços referentes à marcha. Entretanto, os movimentos de juntas característicos da marcha vistos naquela seção são alterados para uma situação onde não há músculos ou nenhum outro elemento promovendo torque ativo diretamente nas juntas do joelho e do tornozelo. A figura 2.15 mostra um gráfico comparativo que ilustra a

\footnotetext{
${ }^{6}$ Ainda que existam tornozelos com mais graus de liberdade, mas esses são bem raros no mercado e menos estudados
} 
variação angular entre um joelho de indivíduo sem amputação e um joelho protético passivo ${ }^{7}$.

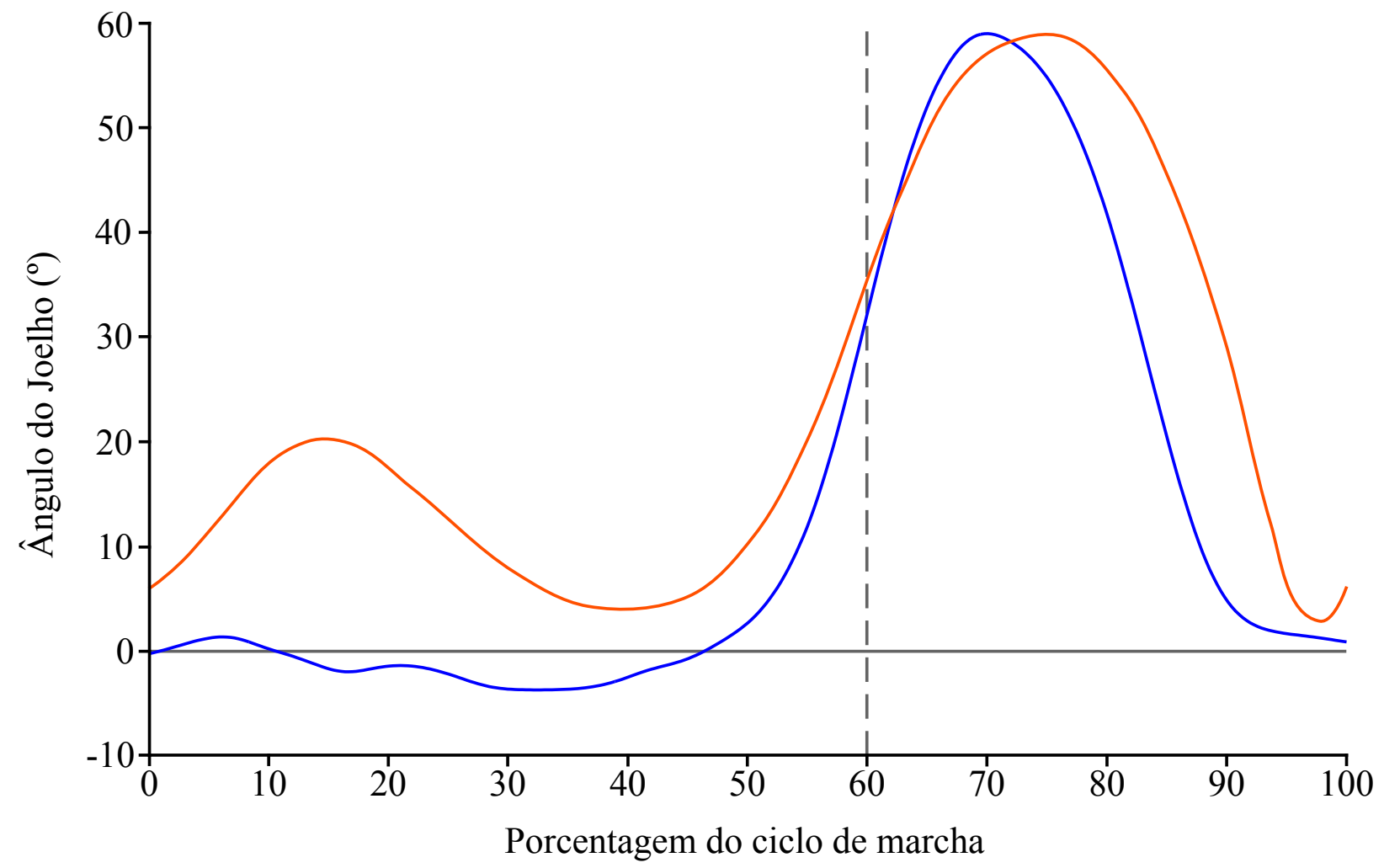

Figura 2.15: Variação angular comparada entre joelho de indivíduo sem amputação (laranja) e joelho protético passivo (azul).

Fica visível pela análise da figura 2.15 que o joelho protético não flexiona significativamente durante a fase de suporte como um joelho de um indivíduo sem amputação. Este pode ser considerado um resultado esperado, visto que, como pudemos analisar na seção 2.1, nessa fase da marcha está ocorrendo a recepção do peso e o suporte simples, duas tarefas que demandam esforços ativos nos joelho para a corretude do movimento. Uma flexão do joelho protético passivo, mesmo que leve, nesse momento causaria potencialmente a queda do usuário pois o próprio peso do indivíduo forçaria a continuação do movimento de flexão descontroladamente.

O movimento de flexão do joelho protético durante a fase de balanço atinge a máxima variação angular de maneira semelhante a um joelho de indivíduo sem amputação. Isso corrobora com a análise feita na seção 2.1 de que esse movimento é dirigido puramente pela inércia do membro sem a ação de um torque ativo na junta.

A junta do tornozelo protético passivo convencional se diferencia ainda mais fortemente do tornozelo natural em termos de moviementação, pois em geral, esses tornozelos não possuem nenhuma articulação, apenas alguma flexibilidade a nível plantar. Dessa forma, não há torque ativo algum que possa ser aplicado nessa junta. Porém, como vimos na seção 2.1, durante a marcha de indivíduos sem amputação fortes esforços ativos são aplicados no tornozelo, então a ausência desses

\footnotetext{
${ }^{7}$ Os gráficos para o indivíduo amputado foram obtidos a partir de dados reais medidos em um voluntário com amputação. O experimento gerador desses dados será visto com maior detalhe no capítulo ??
} 
causa limitações ao usuário, especialmente em modos de marcha que exijam um maior aporte de potência como a subida de escadas ou a corrida.

\subsection{Próteses robóticas}

Próteses robóticas são uma categoria de próteses que, além dos componentes já citados, necessariamente contam com alguma inteligência computacional embarcada e com dispositivos capazes de captar diversas informações e atuar no movimento da prótese e torná-lo mais natural e confortável para o usuário. Essas próteses invariavelmente possuem ao menos um dispositivo de atuação - que efetivamente promove ou interfere no movimento do usuário -, um conjunto mínimo de sensores que medem parâmetros relevantes da prótese e do ambiente ${ }^{8}$ - e um componente computacional - que recebe, processa e emite sinais para os outros componentes da prótese -, além dos próprios componetes mecânicos. A figura 2.16 mostra de forma um diagrama sistemático de uma prótese robótica genérica do qual é possível depreender que o movimento promovido pela prótese é fruto da atuação conjunta dos subsistemas funcionalmente interdependentes entre si atuantes na mesma.

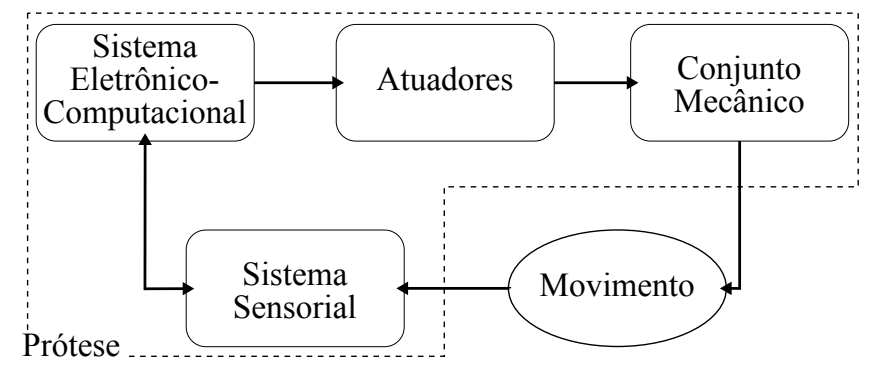

Figura 2.16: Diagrama sistemático generalizado de uma prótese robótica.

Tanto no mercado quanto em desenvolvimento acadêmico, podem ser encontrados diversos exemplos de próteses robóticas de membro inferior. Como exemplo temos o joelho protético CLeg, da Ottobock - visto na figura 2.17 -, que é provavelmente o comercializado do mundo nessa categoria. Teve sua primeira versão apresentada em 1997 e, de acordo com o fabricante foi primeira prótese micro-processado a ser comercializada. Ela é uma prótese com articulação monocêntrica capaz de medir a posição e torque no joelho e, a partir dessas, estimar os instantes de ocorrência dos eventos de contato inicial e de pré-balanço. A C-Leg promove o controle de velocidade do joelho na fase de balanço modulando o amortecimento da junta pelo acionamento de seu atuador hidráulico.

A C-leg foi alvo de diversos estudos clínicos comparativos [35, 40, 41, 42, 43, 44] desde seu lançamento. Um estudo com 19 amputados transfemurais utilizando a C-Leg e uma prótese convencional [43], mostra que a ocorrência de tropeços e quedas é diminuída, além da melhora na qualidade e velocidade da marcha em diferentes modos e terrenos. A medida do consumo de energia feita em [35], com 12 amputados em marcha em velocidade controlada, também mostra redução quando comparada a C-Leg com uma prótese convencional. Entretanto, em relação à cinemática

\footnotetext{
${ }^{8}$ Lembrando que, do ponto de vista de um dispositivo robótico como uma prótese, até mesmo o usuário é considerado um ente do ambiente.
} 


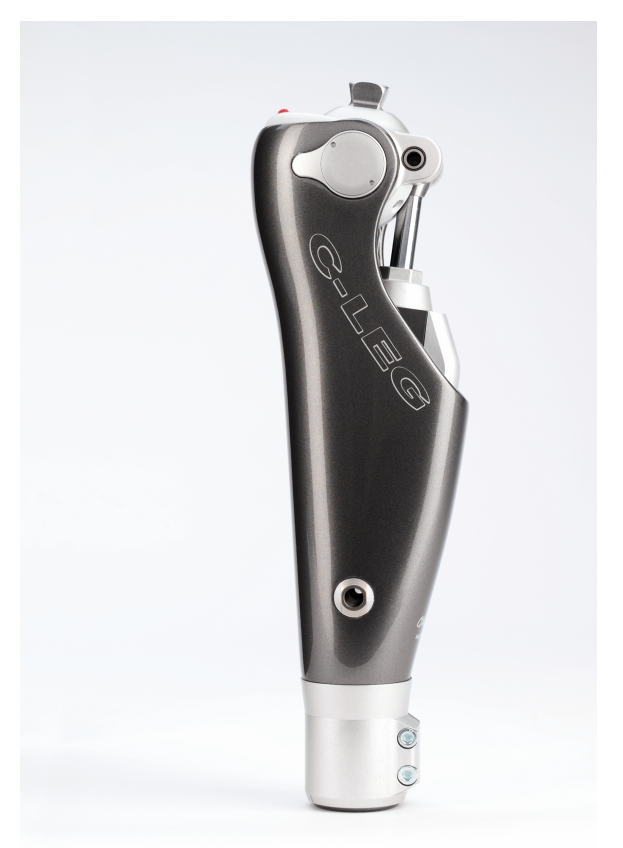

Figura 2.17: Joelho protético microprocessado C-Leg da Ottobock.

do joelho, [44] mostra que não há diferença perceptível de performance entre a C-Leg e uma prótese passiva durante a fase de suporte, não é observada flexão significativa do joelho durante essa fase, tal como ilustra a figura 2.15 , para o caso pasivo.

No que se refere à próteses transtibiais robóticas, a $\mathrm{BiOM}$, da BiOM Personal Bionics (figura 2.18), se mostra como a mais avançada alternativa. Fruto de trabalhos acadêmicos [45, 46, 38] conduzidos no Media Lab, do Massachusetts Institute of Technology (MIT), nos Estados Unidos, começou a ser comercializada em 2013. Trata-se de uma prótese transtibial articulada com um grau de liberdade para movimentação no plano sagital atuada por um motor, com transmissão feita por fuso e castanha, acoplado elemento elásticos em série e em paralelo ${ }^{9}$. Segundo o fabricante e os diversos trabalhos relacionados a $\mathrm{BiOM}$ apresenta uma série de vantagens funcionais em relação às próteses convencionais. Os estudos [47, 38, 48] mostram que, durante o caminhar em superfície plana, a BiOM é capaz de restaurar a biomecânica normal da função do conjunto tornozelo-pé, além de reduzir o custo metabólico utilizando menos energia no caminhar. Em diferentes modos de marcha [49] e também em terrenos irregulares [50] a BiOM apresenta performance bastante superior em termos de esforço físico e velocidade de marcha.

\subsubsection{Sistemas embarcado e sensores}

O sistema embarcado de uma prótese robótica é o sistema responsável por tomar decisões a partir das leituras feitas pelos sensores embarcados e, assim, emitir comandos aos atuadores da prótese. Esse sistema é formado por um subsistema eletrônico, que contém os circuitos de condicionamento dos diversos sinais emitidos e recebidos pelo subsistema computacional, e pelo

\footnotetext{
${ }^{9}$ Esse tipo de conjunto atuador será estudado em detalhe mais adiante ainda nesta seção.
} 


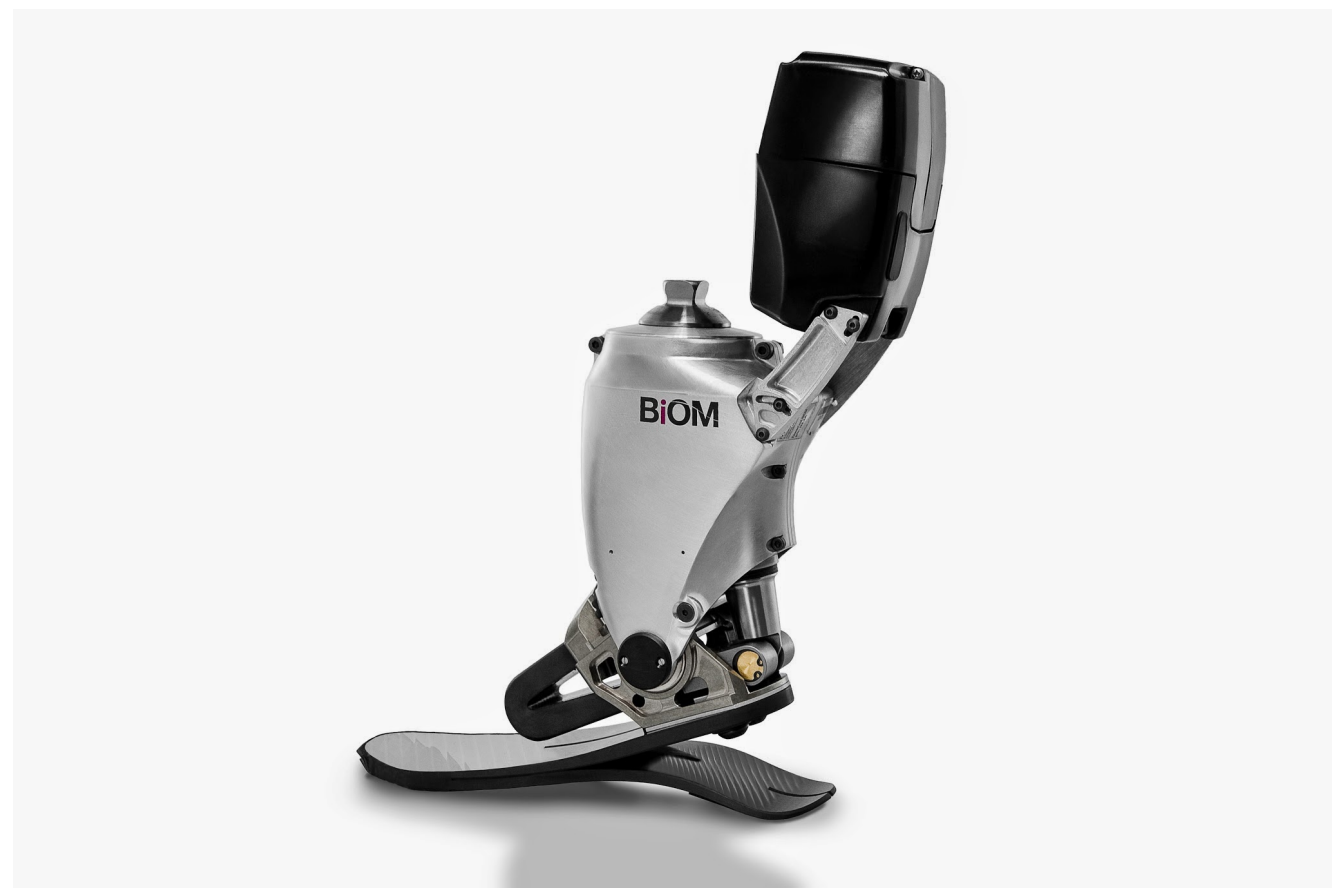

Figura 2.18: Prótese transtibial robótica BiOM, da BiOM Personal Bionics.

próprio subsistema computacional.

O subsistema computacional consiste de um microprocessador que interpreta os sinais, já condicionados pelo subsistema eletrônico, vindos dos sensores e estima o estado em que está a prótese bem como a intensão de movimento do usuário. Então os algortimos de controle executados pelo microprocessador calculam quais devem ser os comandos enviados aos atuadores de forma que a prótese atinja o próximo estado da maneira desejada de acordo com a intensão de movimento do usuário.

O sistema de sensoreamento é formado por um conjunto de sensores que tomam diversas medidas da prótese em tempo real e transmite essas medições para o sistema embarcado, que então as processa e faz as estimativas das quais os algoritmos de controle se valem para a sua execução. São bastante diversos os tipos de informação sensorial e estimativas utilizadas pelos algoritmos de controle. Entretanto, em geral cinco conjuntos de medidas e ou estimativas são as mais utilizadas: deslocamentos angulares das juntas obtidas por meio de encoders; variáveis cinemáticas obtidas por unidades inerciais de movimento; torques e forças de interação entre o usuário e a prótese obtidas por meio de células de carga; torques e forças de interação entre a prótese e o solo com o uso de sensores de pressão plantar; e sinais elétricos captados por meio de eletrodos como a eletromiografia (EMG).

Embora esses sejam os mais comuns, uma prótese robótica pode se valer ainda de outros sensores ou até mesmo somente de alguns desses. Quais tipos de medidas são necessárias são definidas de acordo com o algoritmo de controle utilizado, e, sobretudo, do nível de serviço que se exige da prótese. Enquanto, por exemplo, alguns algoritmos são capazes de usar apenas informações cinemáticas para estimar o estado da prótese com boa precisão, a intensão de movimento pode ser 
mais complexa tanto quanto for complexa a intensão de movimento do usuário, ou seja, quanto mais se exige que a prótese execute movimentos complexos e precisos de acordo com a vontade do usuário, mais informação sensorial é necessária ser fornecida ao algoritmos.

\subsubsection{Atuadores}

A extensa bibliografia sobre próteses, bem como a variada gama de produtos comerciais, mostram que são bastante diversas as estratégias de atuação utilizadas em próteses de membro inferior $[51,52,53,54]$. Desde estratégias passivas - cujas utilizam unicamente a energia do usuário -, com a utilização de elementos mecânicos puramente reativos e resistivos tais como molas e amortecedores pneumáticos simples, até complexas estratégias ativas - que conseguem utilizar uma fonte de energia externa ao usuário -, como motores elétricos e músculos artificiais pneumáticos, utilizadas em próteses robóticas.

Os atuadores de próteses robóticas se utilizam de estratégias ativas de atuação. Todas estas, porém, apresentam algum tipo de vantagem e/ou desvantagem uma em relação à outra. Os motores de corrente contínua por exemplo, são bastante utilizados por terem um acionamento simples e serem capazes de gerar altos torques em associação com elementos passivos como transmissão, entretanto o conjunto motor-transmissão geralmente tem grandes dimensões, o que dificulta sua adaptação às próteses. A figura 2.19 mostra um exemplo de uma prótese transtibial robótica atuada por motores [55], a qual exemplifica as grandes dimensões que uma prótese atuada por motores pode tomar.
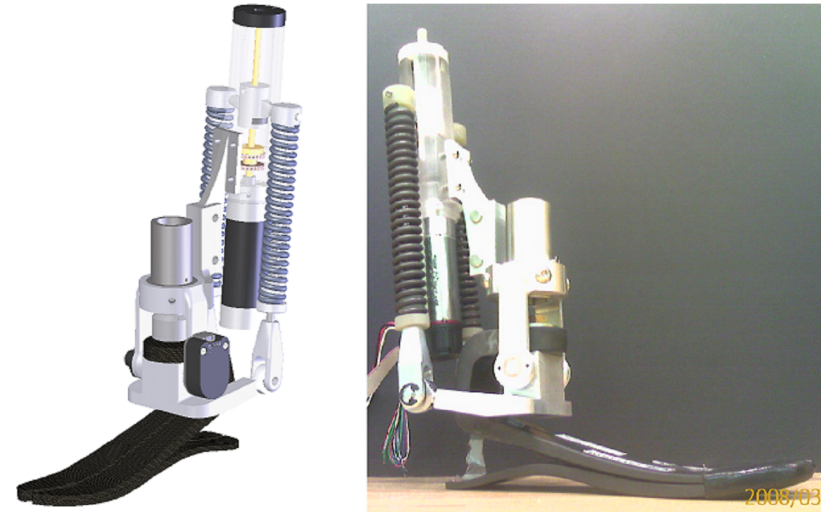

Figura 2.19: Modelo CAD e fotografia de prótese transtibial robótica atuada por motor, SPARKy. Fonte: [56].

Outras alternativas de atuadores presentes na literatura sobre próteses robóticas são os atuadores pneumáticos como os pistões pneumáticos e os músculos artificiais. Esses são conhecidos por promoverem elevadíssimos torques, alta controlabilidade e podendo apresentar dimensões reduzidas - o que facilita consideravelmente sua adaptação às próteses -. Contudo, o acionamento desse tipo de atuador necesssita de algum a equipamento que seja capaz de fornecer a pressão requerida pelo atuador. Este equipamento usualmente é um compressor de ar, o que gera grandes dificuldades para uso em próteses. A difícil portabibilidade dadas suas grandes dimenões e peso, 
alto consumo de energia e constante produção de barulho, são as principais desvantagens desse equipamento tornando impeditivo o seu uso. A figura 2.20 exibe uma prótese transtibial robótica atuada por pistões pneumáticos

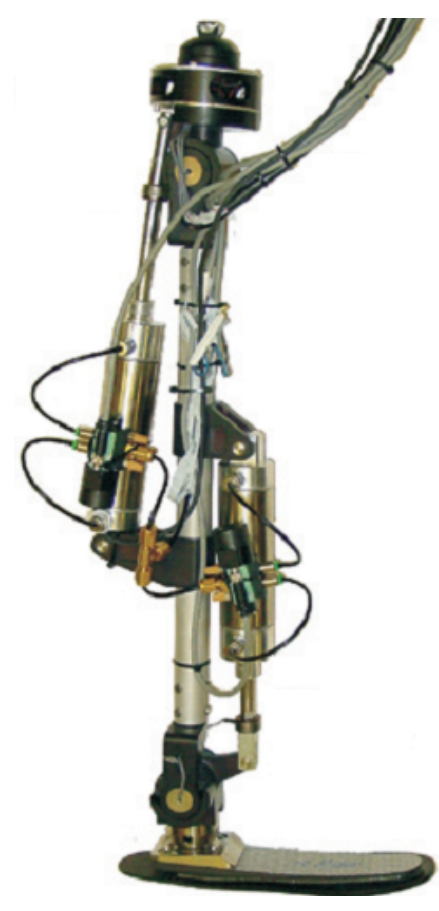

Figura 2.20: Fotografia de prótese transfemural robótica atuada por pistões pneumáticos. Fonte: [57].

De toda forma, os atuadores de próteses robóticas normalmente tentam simular alguma característica dos "atuadores naturais" - os músculos - sendo mais comumente atuadores lineares, ou seja, exercem esforços ao longo de uma trajetória linear tais como pistões e sistemas de fuso e castanha acoplados a motor. Outras características, como elasticidade e capacidade de dissipação de energia de maneira controlável, como ocorre nos músculos, são também bastante desejáveis. A seguir comentaremos em maior detalhe sobre um tipo de atuador que apresenta essas características: o pistão magneto-reológico.

\subsubsection{O pistão magneto-reológico}

Esse dispositivo consiste de um amortecedor no formato de pistão contendo um fluido magnetoreológico (MR) que possui a propriedade de variar sua tensão limite de cisalhamento sob a ação de um campo magnético, resultando em variação na viscosidade aparente do fluido e, conseqüentemente, na constante de amortecimento do pistão [58]. A figura 2.21 exibe um diagrama esquemático simplificado de um atuador MR com seus componentes principais.

Internamente ao êmbolo do pistão uma bobina gera um campo magnético que atua no fluido nas imediações da "válvula"10 do pistão MR. As particulas magnéticas suspensas nesse fluido, então,

\footnotetext{
${ }^{10}$ Apesar de não ser propriamente uma válvula, mas apenas um espaçamento entre o êmbolo e o corpo do pistão, o termo válvula MR se consagrou na literatura - [59], [58], [60] e [61]- pela semelhança com este elemento mecânico
} 


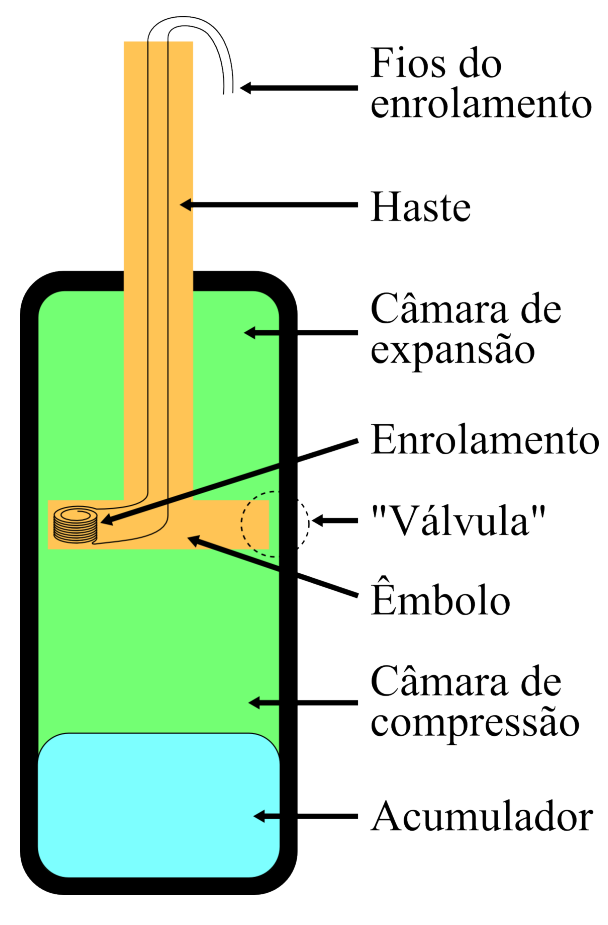

Figura 2.21: Diagrama simplificado de um pistão magneto-reológico com seus principais componentes.

sofrem indução magnética e se polarizam momentaneamente. A forte interação entre os dipólos magnéticos formados organiza as partículas paralelamente ao campo seguindo a extensão da válvula [61]. A força da interação provoca a entrada do fluido em um estado semi-sólido tornando-o menos menos susceptível à atravessar vávula de uma câmara à outra. O grau médio de polarização das partículas e a conseqüente viscosidade aparente do fluido são proporcionais à intensidade do campo gerado pela bobina, que é controlado pela corrente aplicada aos fios do enrolamento. A conseqüência disso é um amortecimento controlável do pistão a partir de uma corrente elétrica. A figura 2.22 mostra uma fotografia de um pistão MR com um esquema em corte exibindo detalhes da estrutura interna do mesmo juntamente com uma representação do campo magnético gerado pela bobina.

Além da câmara que contém o fluido amortecedor MR existe uma segunda câmara - chamada acumulador - isolada do fluido por uma membrana flexível. Essa câmara contém um gás pressurizado e é comprimida conjuntamente com o fluido com o objetivo de acomodar o volume extra adicionado pela haste do pistão, dado que o fluido MR é incompressível [59]. A compressão do gás adiciona uma característica de mola ao pistão em série com o amortecimento, ou seja, o diferencial de pressão aplicado ao pistão pelo acumulador é proporcional à variação da posição do êmbolo. Além dessa característica reativa, o acumulador promove um viés de pressão ao pistão [58], pois o gás do acumulador - tipicamente gás nitrogênio - encontra-se previamente pressurizado na câmara. A figura 2.23 ilustra a dinâmica do acumulador enquanto o pistão é comprimido e se expande.

A composição desses três efeitos - amortecimento, elasticidade e viés - faz com que o pistão exemplificado apresente uma resposta típica para diferentes níveis de corrente como mostrado na que, da mesma forma, tem a função de regular o fluxo do fluido. 


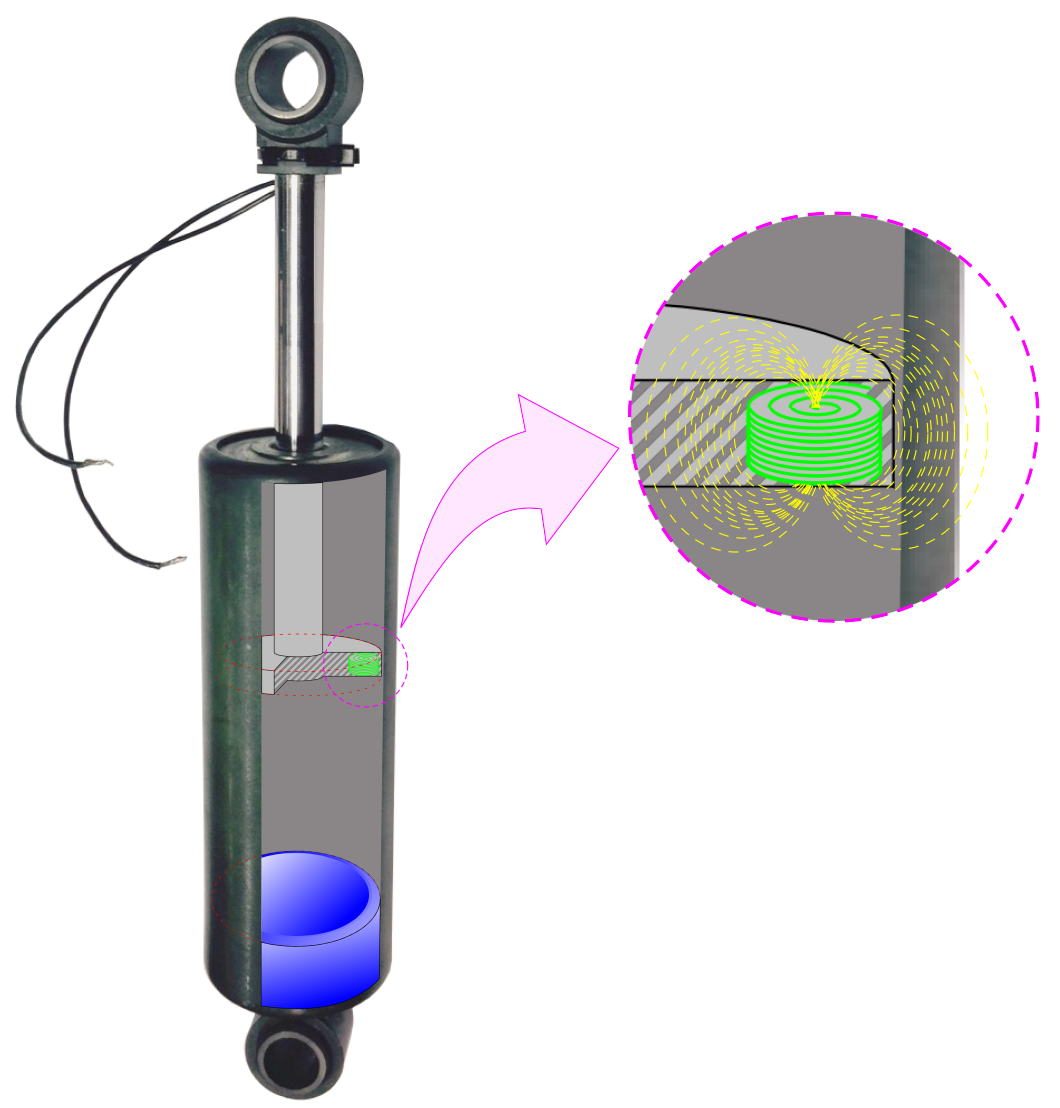

Figura 2.22: Fotografia de um pistão MR com um esquema em corte exibindo detalhes da estrutura interna do mesmo juntamente com uma representação do campo magnético gerado pela bobina.

figura 2.24 .

O gráfico da figura 2.24 exibe a força resistiva exercida pelo pistão para velocidades aplicadas no intervalo $[-0,2 \mathrm{~m} / \mathrm{s} ; 0,2 \mathrm{~m} / \mathrm{s}]$ (sendo o movimento de expansão considerado como o sentido positivo do movimento), para três valores de corrente elétrica - 0;0,5 A e $1 A$ - aplicada aos terminais do pistão MR. Nele é possível observar diversas caracteríticas desse tipo de atuador.

É bastante clara a dependência da corrente elétrica aplicada ao pistão na força resistiva de resposta do atuador, sendo possível determinar a constante de amortecimento do pistão pela razão entre a força e velocidade para cada nível de corrente. Também são notáveis os comportamentos em pré e em pós-cisalhamento do fluido. O pré-cisalhamento se caracteriza pela altíssima constante de amortecimento apresentada pelo fluido observada a baixas velocidades absolutas, enquanto, em comparação, o pós-cisalhamento apresenta amortecimento moderado.

O efeito do offset de força também pode ser observado e facilmente caracterizado nas proximidades da velocidade de compressão nula e sem corrente aplicada, onde o pistão exerce uma força não nula, sendo essa exatamente a força de offset. 

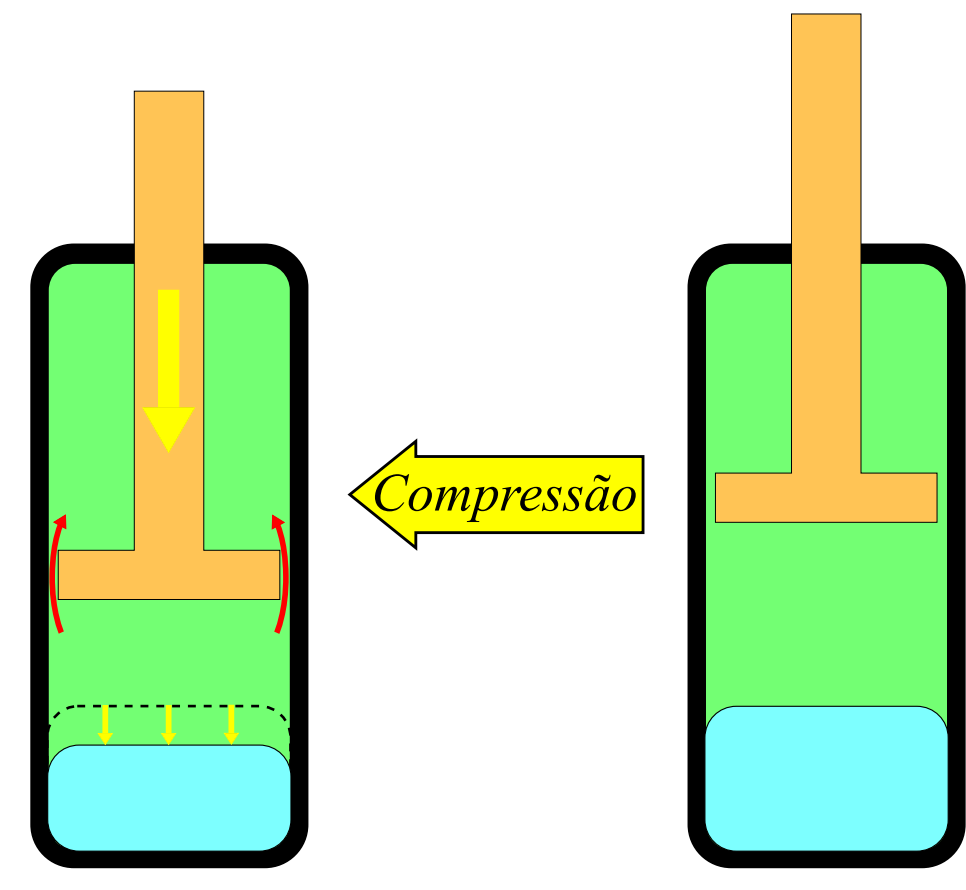

\section{Expansão}

Figura 2.23: Dinâmica do pistão.

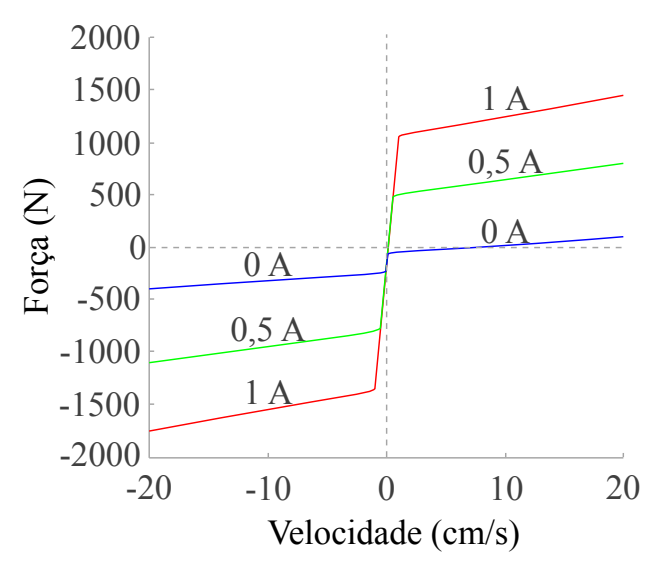

Figura 2.24: Resposta característica de um pistão magneto-reológico para três níveis de corrente: $0 ; 0,5 \mathrm{~A}$ e $1 \mathrm{~A}$. Adaptado de [60] 


\section{Capítulo 3}

\section{Design e Construção do Protótipo}

No presente capítulo será descrita a prótese transfemural robótica de que trata esse trabalho. Em detalhe, são apresentados todos os apectos de sua concepção desde as idéias básicas até o protótipo final. Inicialmente são estabelecidos os requisitos norteadores do projeto essenciais para o desenvolvimento do trabalho. Em seguida, é apresentado um estudo prévio sobre arranjos de quatro barras, no qual será baseado o mecanismo da junta do joelho da prótese. A partir do estudo do mecanismo, passamos aos detalhes da construção do protótipo proposto apresentando os desenhos das peças, simulacões e aspectos da prototipagem e da montagem. Por fim, serão detalhadas as características do atuador magneto-reológico utilizado e seu respectivo acionamento.

\subsection{Aspectos-chave e requisitos de projeto}

O protótipo de prótese transfemural robótica de que trata esse trabalho foi projetado e construído adequando-se às características ressaltadas no capítulo 2 principalmente de segurança, leveza, controlabilidade, conforto e potência. O projeto de prótese foi concebido tendo como principais objetivos norteadores, uma prótese capaz de promover marcha confortável ao usuário; segura dos pontos de vista estrutural, elétrico e funcional; capaz de exercer movimentos e esforços compatíveis com as atividades perfeitas pelo usuário e inteligente o suficiente para ser capaz de entender a intenção de movimento do usuário, tomar a decisão correta e acionar corretamentamente os atuadores para um movimento correto. Para atingir esses objetivos primeiramente foram selecionados o mecanismo do joelho e a estratégia de atuação: o mecanismo policêntrico de quatro barras e o pistão magneto-reológico.

Como visto no capítulo 2 esse tipo de mecanismo, similar ao joelho humano saudável, permite o posicionamento do centro instantâneo de rotação (CIR) de forma conveniente em diferentes instantes da marcha. Assim, se durante a fase de suporte posicionarmos o CIR posteriormente à linha de carga - linha teórica que centra os esforços devidos à reação no solo ao peso do indivíduo, que coincide com a linha entre o trocânter ${ }^{1}$ e o tornozelo durante o suporte -, podemos conferir à junta maior estabilidade e segurança. Mais ainda, o encurtamento mencionado naquele capítulo,

\footnotetext{
${ }^{1}$ Protuberância óssea na parte superior do fêmur.
} 
que ocorre naturalmente em um joelho normal, pode ser também emulado pelo mecanismo de quatro barras. Dessa forma, o uso desse mecanismo foi tomado como um requisito de projeto.

A escolha do atuador foi então baseada em três requisitos: um atuador que pudesse ser controlado eletronicamente, que se adequasse à geometria proposta e que fornecesse potência resistiva suficiente ao movimento da junta. O atuador magneto-reológico LORD ${ }^{\circledR} \mathrm{RD}-8040-1^{2}$ - produzido pela LORD ${ }^{\circledR}$ Corporation, Estados Unidos - foi então escolhido por oferecer essas características. É um atuador linear com características resistivas e reativas, que se encaixa dentro da geometria do mecanismo e é controlado pela aplicação de uma corrente elétrica.

Já para a junta do tornozelo foi adotado um modelo com somente um grau de liberdade para movimentação no plano sagital, atuada por um atuador série-elástico. Entretanto para fins de teste do joelho, dado que o conjunto tornozelo-pé protético não foi construído durante o tempo de execução deste trabalho de mestrado, foi utilizado o pé de carbono 1 C30 Trias $^{\circledR}$ Ottobock ${ }^{\circledR}$, Alemanha.

Além disso componentes comerciais - extensor tibial, acessórios de fixação e soquete para coto femural - completam a estrutura mecânica da prótese. Os acessórios de fixação, o comprimento do extensor tibial e o formato do soquete devem ser sempre customizados para cada usuário. Assim, toda a prótese foi concebida para o uso com um voluntário amputado, adaptando-se à sua altura, peso, formato do coto de amputação, comprimento do membro residual e nível de atividade. O processo de protetização, ou seja, a aplicação da prótese ao usuário levando em conta suas características corporais e funcionais, foi todo feito com o trabalho de um protesista contratado, que é o profissional habilitado e com a experiência necessária para esse trabalho. Conforme visto no capítulo 2, uma protése mal ajustada ao usuário pode ser bastante danosa ao mesmo, sendo então imprescindível o trabalho do protesista.

A prótese desenvolvida conta com um sistema embarcado composto por um microcontrolador que concentra toda a inteligência do dispositivo e toma decisões a partir da leitura dos sensores, para o envio de referências para os atuadores ${ }^{3}$. O sistema de sensoreamento é composto por instrumentos de medição de aceleração, velocidade e campo magnético integrados em uma unidade inercial de movimento, além de um encoder absoluto de alta qualidade, em temos de precisão e resolução, para a medição do ângulo do joelho. O acionamento dos atuadores é feito por meio de drivers de potência que recebem o sinal de referência do microcontrolador e fornece a potência requerida para a ação dos atuadores.

As figuras 3.1a e $3.1 \mathrm{~b}$ exibem respectivamente a prótese ainda em sua primeira montagem, onde estão presentes somente o joelho protético com o atuador instalado e com um soquete provisório, e sua montagem atual já com todo o sistema embarcado e de sensoreamento incorporados.

\footnotetext{
${ }^{2}$ Gentilmente cedido pela divisão brasileira da LORD $^{\circledR}$ Corporation.

${ }^{3} \mathrm{O}$ sistema de controle de alto nível do dispositivo foi desenvolvido por outro pesquisador membro do grupo de trabalho e não é detalhado no presente trabalho.
} 


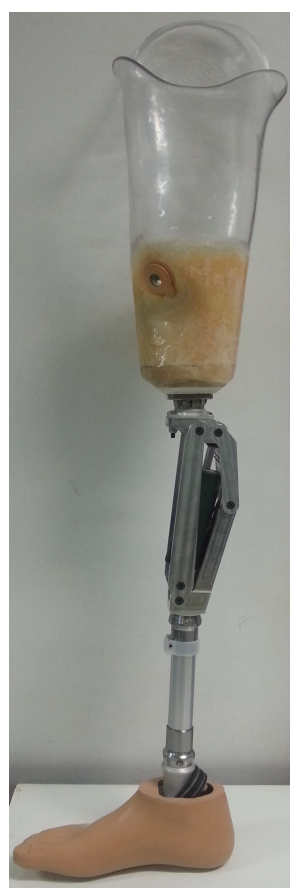

(a)

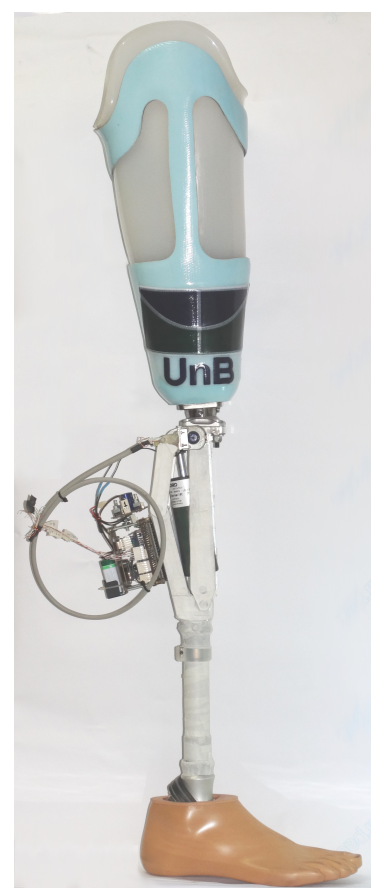

(b)

Figura 3.1: Protótipo em dois momentos: (a) montado e com o atuador acoplado, ainda com soquete provisório; (b) protótipo funcional, com sistema embarcado e sensores acoplados.

\subsection{O mecanismo de quatro barras}

\subsubsection{Modelo cinemático básico}

Dos inúmeros arranjos mecânicos que apresentam essa característica policêntrica, destaca-se o mecanismo de quatro barras, um mecanismo clássico e bastante conhecido em mecânica formado por quatro elos unidos dois a dois por juntas rotativas em uma cadeia cinemática fechada. Vale ressaltar que esse é um arranjo bastante presente na natureza. Por exemplo, diversas articulações nos animais podem ser modeladas por um arranjo desse tipo, inclusive o próprio joelho humano. A figura 3.2 exibe um diagrama esquemático de um mecanismo de quatro barras genérico. 


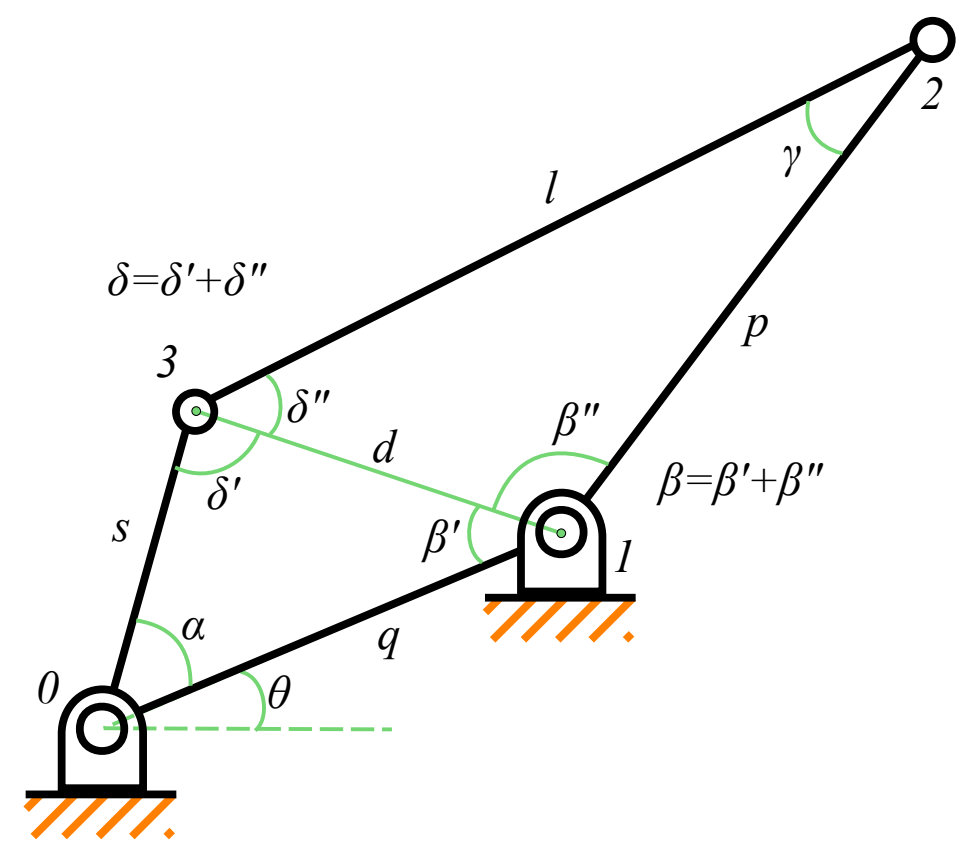

Figura 3.2: Arranjo de quatro barras genérico (barras e juntas rotacionais representadas em preto).

No arranjo ilustrado na figura 3.2 vemos as quatro barras $s, l, p$ e $q$ unidas por juntas rotacionais numeradas de 0 a 3 . As juntas 0 e 1 são fixas com deslocamento angular $\theta$ entre as mesmas e a horizontal, além da diagonal teórica $d$ entre as juntas 1 e 3 . Tomando o ângulo $\alpha$ como dimensão acionadora, os outros ângulos de junta podem ser determinados a partir das equações a seguir. Tal análise cinemática pode auxiliar não apenas em estudos biomecânicos de marcha em indivíduos amputados, mas também na otimização de projetos de próteses transfemurais.

Primeiramente aplicamos a lei dos cossenos para obter $\gamma$ em função de $\alpha$.

$$
\begin{gathered}
d=\sqrt{s^{2}+q^{2}-2 s q \cos \alpha}=\sqrt{l^{2}+p^{2}-2 l p \cos \gamma} \\
\gamma=\operatorname{acos}\left(\frac{l^{2}+p^{2}-s^{2}-q^{2}+2 s q \cos \alpha}{2 l p}\right)
\end{gathered}
$$

Em seguida aplicamos a lei dos senos para a obtenção de $\beta$ e $\delta$ em função de $\alpha$ e $\gamma \cdot{ }^{4}$

$$
\begin{gathered}
\frac{d}{\operatorname{sen} \alpha}=\frac{s}{\operatorname{sen} \beta^{\prime}}=\frac{q}{\operatorname{sen} \delta^{\prime}} \\
\beta^{\prime}=\operatorname{asen}\left(\frac{s}{d} \operatorname{sen} \alpha\right) \\
\delta^{\prime}=\operatorname{asen}\left(\frac{q}{d} \operatorname{sen} \alpha\right)
\end{gathered}
$$

\footnotetext{
${ }^{4}$ Importante ressaltar que os dois triângulos formados pelas barras e pela diagonal devem sempre respeitar a propriedade da soma dos ângulos internos, ou seja, $\alpha+\beta^{\prime}+\delta^{\prime}=180^{\circ}$ e $\gamma+\beta^{\prime \prime}+\delta^{\prime \prime}=180^{\circ}$.
} 


$$
\begin{gathered}
\frac{d}{\operatorname{sen} \gamma}=\frac{l}{\operatorname{sen} \beta^{\prime \prime}}=\frac{p}{\operatorname{sen} \delta^{\prime \prime}} \\
\beta^{\prime \prime}=\operatorname{asen}\left(\frac{l}{d} \operatorname{sen} \gamma\right) \\
\delta^{\prime \prime}=\operatorname{asen}\left(\frac{p}{d} \operatorname{sen} \gamma\right) \\
\beta=\beta^{\prime}+\beta^{\prime \prime} \\
\delta=\delta^{\prime}+\delta^{\prime \prime}
\end{gathered}
$$

Dessa forma vemos que todos os ângulos de junta ficam determinados à partir da dimensão acionadora.

A figura 3.2 exibe o arranjo de quatro barras em sua configuração aberta - na qual o arranjo descreve um quadrilátero convexo -, entretanto o equacionamento mostrado de 3.1 a 3.10 também modela as configurações fechada - cuja descreve um quadrilátero côncavo - e cruzada - quando ocorre o cruzamento de duas barras opostas--. A figura 3.3 exibe essa duas configurações.

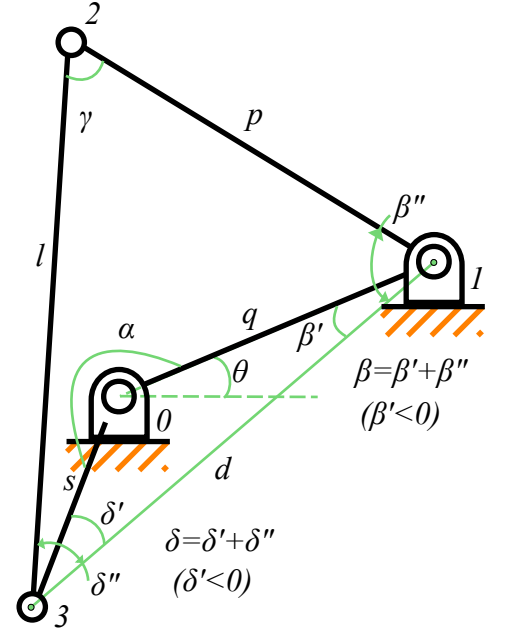

(a)

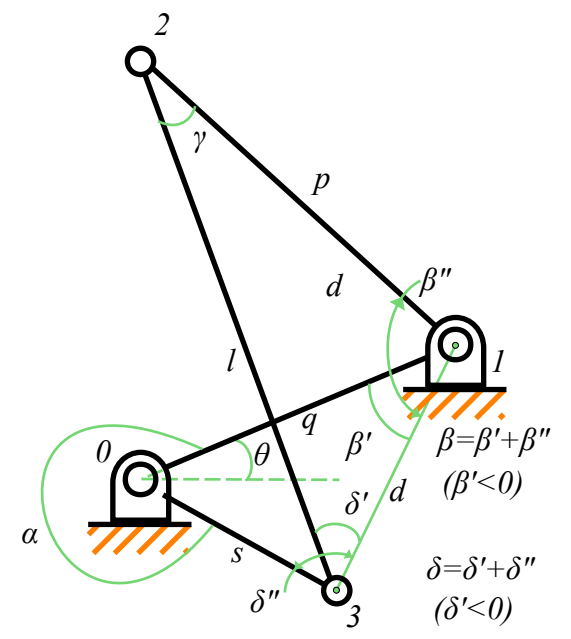

(b)

Figura 3.3: Arranjo de quatro barras em suas configurações: (a) Fechada; (b) Cruzada.

Nota-se que o a diagonal $d$ está oposta aos ângulos $\alpha$ e $\gamma$ nas três configurações. Então aplicação da lei dos cossenos na equação 3.1 e da lei dos senos nas equações 3.3 e 3.6 para a obtenção dos ângulos arranjo se mantém em todas as configurações. Ressalta-se apenas a mudança no sinal dos ângulos $\beta^{\prime}$ e $\delta^{\prime}$, já que a ordem dos segmentos que define esses ângulos se inverte. 


\subsubsection{O posicionamento do centro instantâneo de rotação}

Conhecendo todos os ângulos do mecanismo, passamos agora ao cálculo da posição do CIR entre as barras $s$ e $p$, localizado no encontro das retas suporte das mesmas ${ }^{5}$. A figura mostra o mesmo esquema da figura 3.4 evidenciando a posição geométrica do referido CIR, aqui chamado de $C I R_{s p}$.

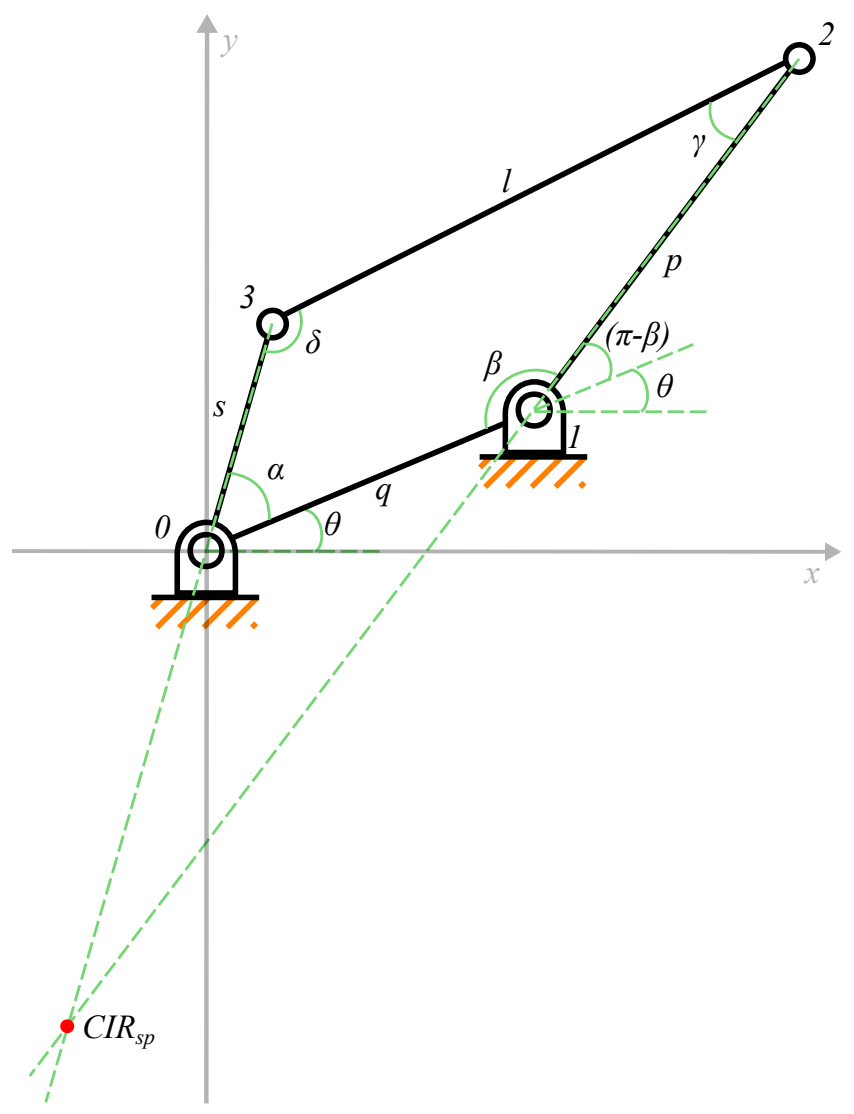

Figura 3.4: Exemplo genérico do posicionamento de um CIR do arranjo de quatro barras.

Adotando junta 0 como origem dos eixos coordenados como na figura, ou seja, $\left(x_{0}, y_{0}\right)=(0,0)$, podemos definir a posição da junta 1, bem como as equações das retas suporte das barras $s$ e $p$ como mostramos nas seguintes equações, nas quais faremos a substituição de variáveis $\varphi=\alpha+\theta$ e $\rho=\pi-\beta+\theta$, por simplicidade na notação:

$$
\begin{gathered}
\left(x_{1}, y_{1}\right)=(q \cdot \cos \theta, q \cdot \operatorname{sen} \theta) \\
s: \quad y_{s}-y_{0}=\left(x_{s}-x_{0}\right) \operatorname{tg} \varphi \\
y_{s}=x_{s} \cdot \operatorname{tg} \varphi
\end{gathered}
$$

${ }^{5}$ A rigor, o encontro das retas suporte de duas barras quaisquer do mecanismo define um CIR, porém, por simplicidade, os cálculos dos demais CIR's não são apresentados dado que os mesmos são análogos. 


$$
\begin{gathered}
y_{p}-y_{1}=\left(x_{p}-x_{1}\right) \operatorname{tg} \rho \\
y_{p}=x_{p} \cdot \operatorname{tg} \rho-x_{1} \cdot \operatorname{tg} \rho+y_{1}
\end{gathered}
$$

Assim, podemos calcular a posição do $C I R_{s p}$, no ponto $\left(x_{c}, y_{c}\right)$ de encontro das retas suporte das barras $s$ e $p$, onde as duas retas têm coordenadas iguais, ou seja, $\left(x_{s}, y_{s}\right)=\left(x_{p}, y_{p}\right)=\left(x_{c}, y_{c}\right)$.

$$
\begin{gathered}
y_{s}=y_{p} \\
x_{s} . t g \varphi=x_{p} \cdot t g \rho-x_{1} \cdot \operatorname{tg} \rho+y_{1} \\
x_{c}=\frac{y_{1}-x_{1} \cdot \operatorname{tg} \rho}{\operatorname{tg} \varphi-\operatorname{tg} \rho} \\
y_{c}=\frac{y_{1} \cdot t g \varphi-x_{1} \cdot \operatorname{tg} \varphi \cdot t g \rho}{\operatorname{tg} \varphi-\operatorname{tg} \rho}
\end{gathered}
$$

Dessa forma, sendo dados os comprimentos das barras e o deslocamento angular $\theta$, vemos que também a posição do CIR depende exclusivamente da dimensão acionadora $\alpha$. Mais ainda, podemos dimensionar os comprimentos das barras de maneira a obter um posicionamento conveniente do CIR.

À rigor, toda intersecção das retas suporte de quaisquer duas das barras do arranjo dá origem a um CIR que também pode ter sua posição calculada. Entretanto, dada a generalidade dos cálculos estabelecidos, o cálculo das posições dos CIR's podem ser feitos a partir da mesma seqüência de equações.

\subsubsection{O encurtamento aparente do mecanismo de quatro barras}

Para então estudarmos a mudança aparente no comprimento do mecanismo como citado anteriormente. A figura 3.5 mostra o mecanismo das figuras anteriores em dois instantes, $k$ e $k^{\prime}$, nos quais estão marcados vermelho e amarelo dois pontos ligados respectivamente às barras $q$ e $l$ nos dois instantes. 


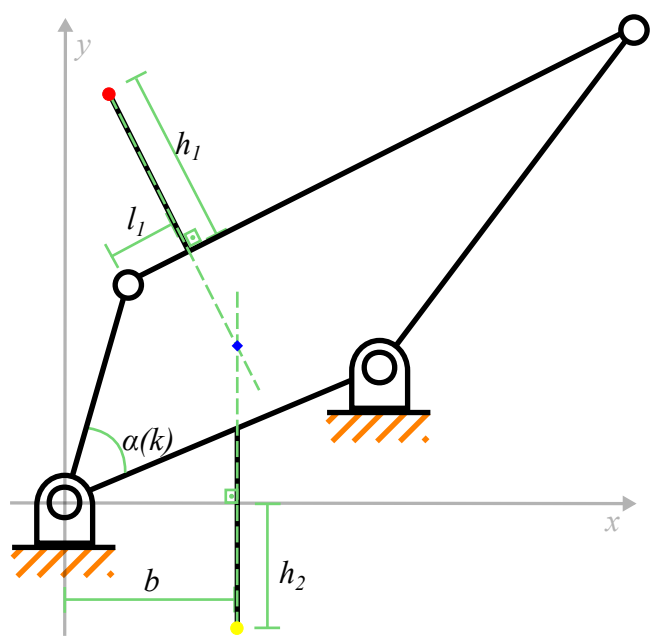

(a)

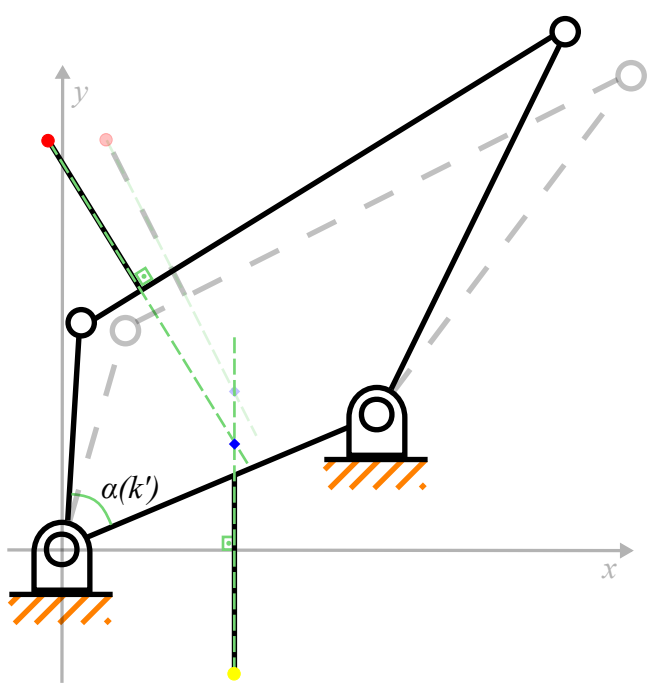

(b)

Figura 3.5: Exemplo genérico da alteração da distâncias entre pontos fixos a duas barras do arranjo de quatro barras.

A distância entre os pontos vermelho e amarelo passando pelo ponto azul - que representa o ponto em coincidem as retas suporte dos segmentos que unem os pontos vermelho e amarelo às suas respectivas barras - pode ser calculada pela seguintes equações.

Primeiramente calculamos a posição $\left(X_{v}, Y_{v}\right)$ do ponto vermelho em função de $\alpha$.

$$
\left\{\begin{array}{l}
X_{v}(\alpha)=s \cdot \cos (\alpha+\theta)+l_{1} \cdot \cos (\alpha+\theta+\delta-\pi)+h_{1} \cdot \cos \left(\alpha+\theta+\delta-\frac{\pi}{2}\right) \\
Y_{v}(\alpha)=\operatorname{sen}(\alpha+\theta)+l_{1} \cdot \operatorname{sen}(\alpha+\theta+\delta-\pi)+h_{1} \cdot \operatorname{sen}\left(\alpha+\theta+\delta-\frac{\pi}{2}\right)
\end{array}\right.
$$

Então calculamos a equação da reta $r$ perpendicular a barra $l$ que passa pelo ponto vermelho.

$$
y_{r}(\alpha)=\left(x_{r}(\alpha)-X_{v}\right) \cdot \tan \left(\alpha+\theta+\delta-\frac{\pi}{2}\right)+Y_{v}
$$

Conhecendo a abcissa do ponto azul calculamos então a posição $\left(X_{a}, Y_{a}\right)$ do ponto azul em função de $\alpha$.

$$
\left\{\begin{array}{l}
X_{a}(\alpha)=b \\
Y_{a}(\alpha)=\left(b-X_{v}\right) \cdot \tan \left(\alpha+\theta+\delta-\frac{\pi}{2}\right)+Y_{v}
\end{array}\right.
$$

Por fim calcula-se a distância $D$ do ponto vermelho ao ponto amarelo passando pelo ponto azul.

$$
D=\sqrt{\left(X_{v}-X_{a}\right)^{2}+\left(Y_{v}-Y_{a}\right)^{2}}+\left|Y_{a}+h_{2}\right|
$$

Assim demonstra-se que a distância entre dois pontos arbitrariamente escolhidos em duas barras do mecanismo se afastam ou se aproximam conforme variamos o ângulo $\alpha$. Mais que isso, não somente pontos sobre as barras têm essa propriedade, mas quaisquer pontos solidariamente unidos às barras. 


\subsection{Modelagem mecânica do joelho protético}

Baseado no mecanismo estudado na seção 3.2 passamos à modelagem das peças componentes dos mecanismos das juntas. Para a junta do joelho, primeiramente, definimos que na posição estendida do joelho o CIR estaria posicionado na região posterior à linha de carga e acima do plano perpendicular à linha de carga e passante pelo centro de rotação base (centro de rotação do joelho solidário ao soquete). Essa é uma posição utilizada para permitir o bloqueio da flexão do joelho durante a fase de suporte da marcha [62]. Outra definição tomada para o mecanismo do joelho é que ele apresentasse um encurtamento aparente sensível, para permitir maior liberação de espaço entre pé e a superfície durante a fase de balanço. Por fim, deifnimos que o mecanismo deveria encapsular o atuador já escolhido, o pistão MR.

Dadas essas definições foram escolhidas as posições relativas das juntas rotativas entre as barras e, portanto, o comprimento das barras para a posição completamente estendida do joelho. Uma simulação foi, então, criada no software matemático MATLAB ${ }^{\circledR}$ para avaliar a movimentação das barras e encurtamento durante o balanço.

Para melhor avaliação do dispositivo, modelos 3D das peças foram criados utilizando o software de CAD Solidworks ${ }^{\circledR}$. O uso de uma ferramenta de CAD é uma etapa crucial do processo de modelagem, pois nessa podemos criar e simular diversas peças e arranjos mecânicos de forma que atendam aos requisitos. Por meio desse software avaliamos de maneira simulada os componentes e as montagens dos mesmos quanto a movimentação, caracteríticas mecânicas do material e as respostas estática e dinâmica a esforços internos e externos. Nos testes de movimentação avaliamos como as peças se movimentam umas em relação às outras verificando e corrigindo a ocorrência de choques ou interferências indesejadas, folgas e desalinhamentos. Avaliamos também a distribuição de esforços nas peças por análise de elementos finitos.

\subsubsection{Simulações numéricas e CAD}

O equacionamento estabelecido na seção 3.2, foi implementado em um código no MatlaB para a simulação de mecanismo de quatro barras. O código recebe como entrada os comprimentos das barras e a angulação entre as duas juntas fixas. Para cada valor da unidade acionadora, o código apresenta como resultado de forma gráfica e numérica as barras, o percurso do CIR e o encurtamento. Então, simulando o modelo para ínumeros conjuntos de valores de barras, foram encontradas configurações que atendiam aos requisitos estabelecidos de posicionamento do CIR e de encurtamento. A figura 3.6 mostra uma seqüência de imagens resultantes do código, simuladas para o conjunto de barras adotado para o protótipo à ser apresentado a seguir na subseção 3.3.3. 


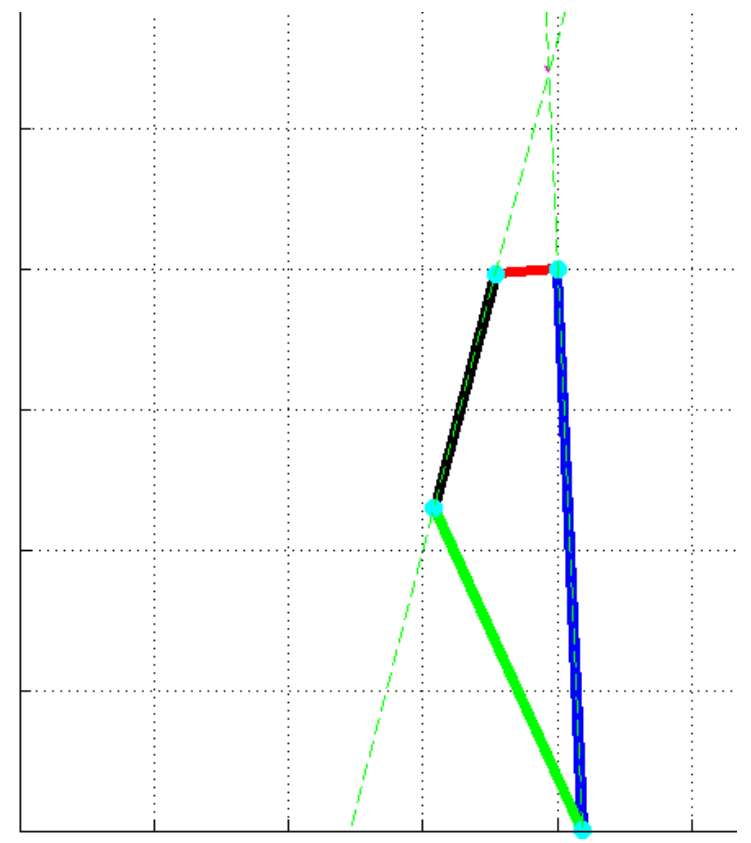

(a)

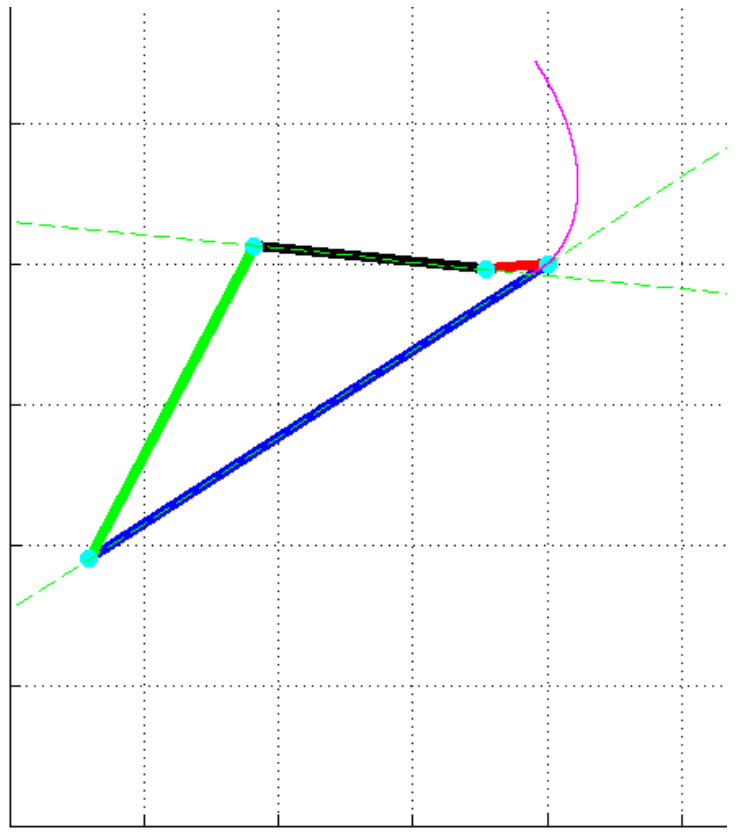

(c)

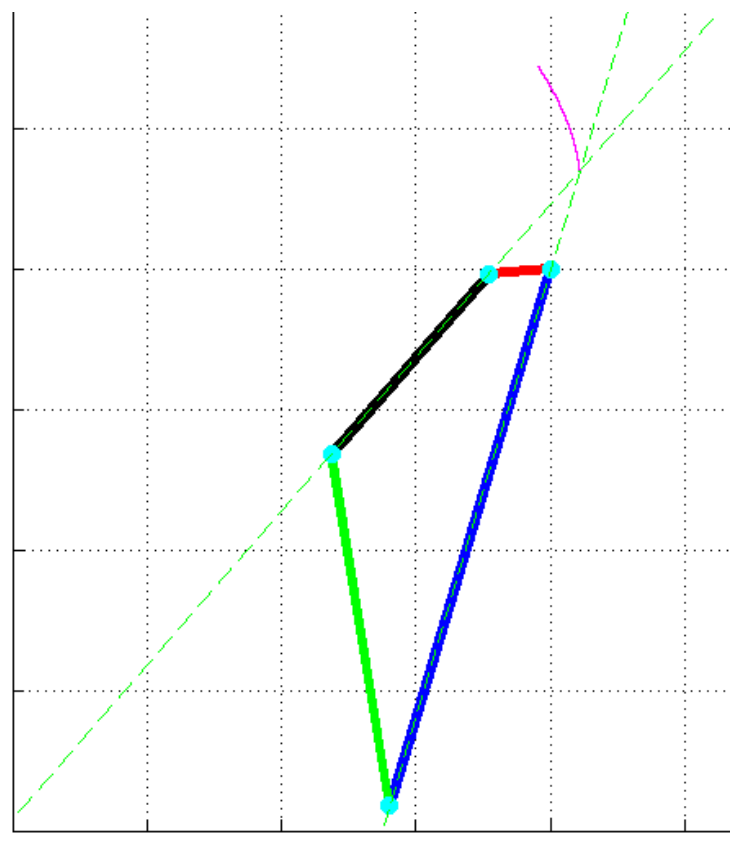

(b)

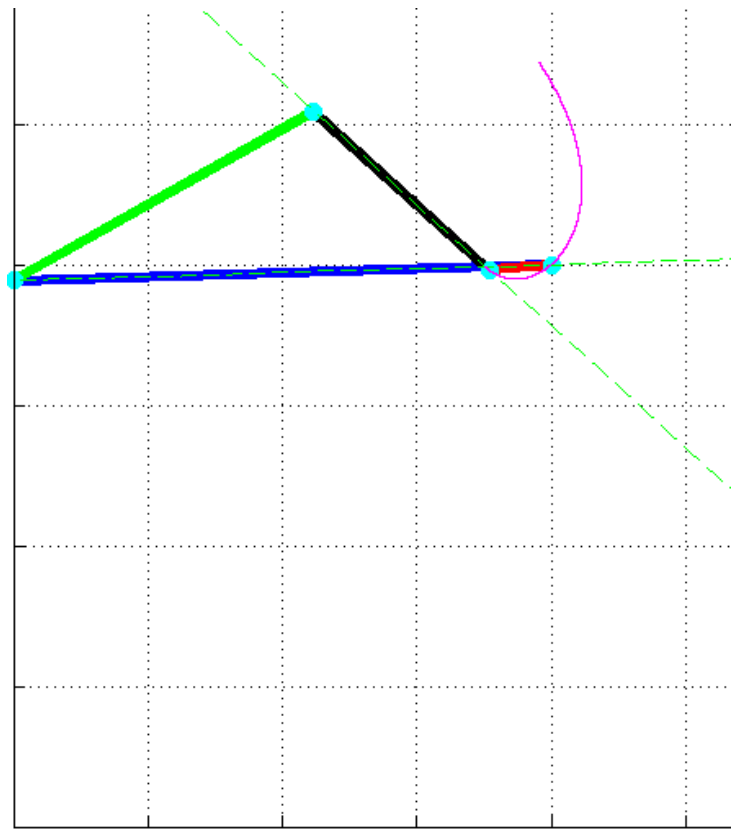

(d)

Figura 3.6: Posições da simulação do arranjo de quatro barras mostradas sequencialmente de (a) até (d). Em magenta estão representadas as posições do CIR e sua evolução.

Na figura 3.6 é possível ver em seqüência quatro posições do arranjo de quatro barras simulado. Tomando como unidade acionadora o ângulo entre a barra vermelha fixa e a barra azul móvel variante entre $90^{\circ}$ e $0^{\circ}$-, vemos a evolução do posicionamento das barras e do CIR em magenta. As linhas tracejadas em verde representam as retas suporte das barras para as quais é calculada o CIR.

De posse do resultado das simulacões numéricas, passamos ao projeto do mecanismo no software 
de CAD. Era necessário um modelo que respeitasse o comprimento das barras e as dimensões do atuador escolhido. Então diversas alternativas de modelo foram projetadas e avaliadas em termos de dimensões, movimentação e adequação às dimensões do atuador. Finalmente, como pode ser visto na figura 3.7, um modelo com essas características foi adotado e confeccionado.

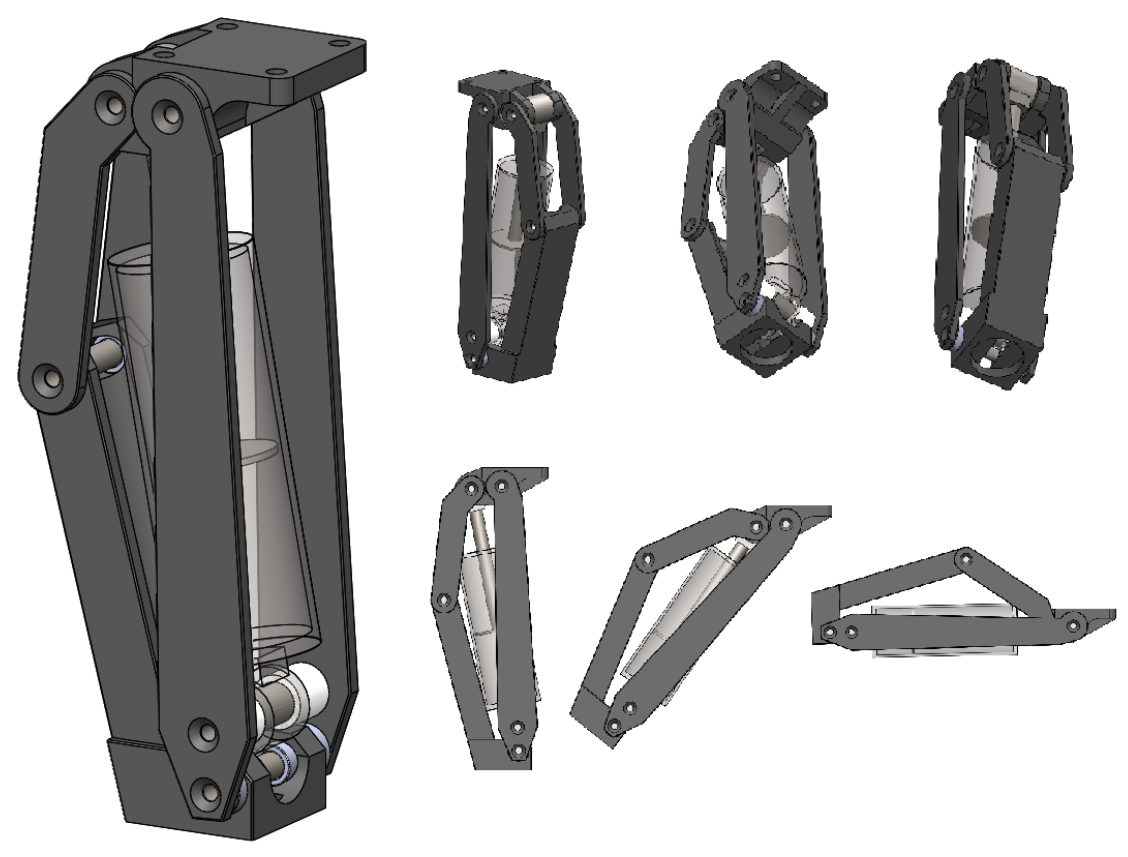

Figura 3.7: Modelo CAD final do mecanismo representado em diferentes posicionamentos.

\subsubsection{Análise estrutural do dispositivo}

A análise estrutural do dispositivo permite avaliar manutenção de sua integridade estrutural sob a ação de esforços internos e externos, além de dar base para possíveis otimizações do no desenho das peças, escolha do material e elementos de fixacão. Esse análise é de vital, importância para o projeto, uma vez que escolhemos uma relação de compromisso entre segurança estrutural e peso do dispositivo. Em geral, quanto mais material tem uma peça tem uma peça mecânica mais robusta a falhas estruturais, mas também mais pesada. No caso de uma prótese, cuja leveza é um requisito crucial, a análise da estrutura do dispositvo faz-se de extrema necessidade tanto para garantir que as peças não falhem, quanto para otimizar o uso de material.

A referida análise das peças componentes do joelho protético foi realizada por meio da Análise de Elementos Finitos (FEA - sigla em inglês). O método de análise de estruturas mecânicas pela FEA, já bastante consolidado na literatura, discretiza um ente mecânico complexo - por exemplo em sua geometria - dividindo-o em um número muito grande de pequenos elementos simples e estuda a interação mecânica entre cada um deles e os elementos vizinhos. A integração de todas as interações de todos os elementos permite aproximar numericamente diversas caracteristicas mecânicas do ente com bastante precisão. Em geral a aproximação será tão boa quanto menores os elementos analisados. Os resultados da análise permitem prever em cada ponto da estrutura escoamento, magnitude das deformações elásticas e plásticas ou até mesmo ruptura da estrutura 
de acordo com a distribuição de cargas aplicadas.

Para a FEA, executada no software Solidworks ${ }^{\circledR}$, realizar as simulações são utilizados como dados de entrada: desenho CAD da peça, material escolhido, restrições dos apoios e as cargas aplicadas. Em uma primeira simulação não foi realizada como uma montagem completa. Cada peça foi simulada separadamente, sendo as cargas nos apoios transferidas para a peça seguinte, excluindo-se assim as análises de contato entre as peças. Desse maneira, também foram excluídas das análises os acessórios de fixação e eixos, pois o foco foi o comportamento estático de cada componente principal. Como resultado das simulações, foram obtidas figuras representativas das tensões estáticas distribuídas em cada componente individualmente, suas respectivas deformações e deslocamentos.

A tabela 3.1 exibe os parâmetros estruturais das peças componentes do protótipo utilizados na simulação $0^{6}$.

\begin{tabular}{ccccc}
\hline Componente & Material & $\begin{array}{c}\text { Módulo de } \\
\text { elasticidade }\end{array}$ & $\begin{array}{c}\text { Tensão } \\
\text { limite de } \\
\text { escoamento }\end{array}$ & $\begin{array}{c}\text { Resistência } \\
\text { à tração }\end{array}$ \\
\hline Estrutura & $\begin{array}{c}\text { Liga de } \\
\text { alumínio } 7050\end{array}$ & $72 G P a$ & $490 M P a$ & $550 M P a$ \\
Buchas & Teflon & $1 G P a$ & $60 M P a$ & $79 M P a$ \\
Eixos & Aço 1045 & $205 G P a$ & $530 M P a$ & $625 M P a$ \\
\hline
\end{tabular}

Tabela 3.1: Parâmetros estruturais das peças componentes do protótipo.

A análise de cada resultado permite uma visão global dos estado de tensões da prótese, bem como possíveis locais de falha e pontos de otimização do material. Deve-se ressaltar que as análises elaboradas, não refletem a realidade quantitativa da prótese na sua totalidade, pois foram estudos elaborados de forma simplificada e sem análises dinâmicas do mecanismo, entretanto os resultados nos permitem a definição de limites de aplicação de esforços à estrutura, o que já são dados suficientes para definição de níveis de segurança. A figura 3.8 exibe os principais resultados obtidos para as tensões equivalentes de von Mises obtidas para as simulações

A análise foi elaborada dadas as seguintes restrições: apenas análises estáticas; cada peça foi simulada separadamente; todas as peças foram consideradas engastadas em seu ponto de fixação; carga externa aplicada de $1000 N$; carga total do pistão considerada constante de $100 N$. O valor da carga externa foi arbitrariamente escolhido para ser ligeiramente maior que a maior força de reação no solo a que está subemetido a prótese para o caminhar do voluntário amputado usuário da prótese. De acordo com [5], durante esse modo de marcha a força de reação no solo atinge o máximo $120 \%$ do peso do indivíduo. O voluntário tem um peso aproximado de $800 N$ então o valor arbitrário escolhido para a carga externa representa suficentemente o máximo valor de reação no solo de, nesse caso, 960N. Já o valor da carga interna foi arbitrariamente escolhido por pouco interferir no resultado dessa simulação estática.

\footnotetext{
${ }^{6}$ Os valores apresentados na tabela são fornecidos pelo próprio software de CAD utilizado.
} 


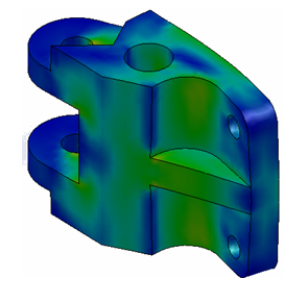

(a)

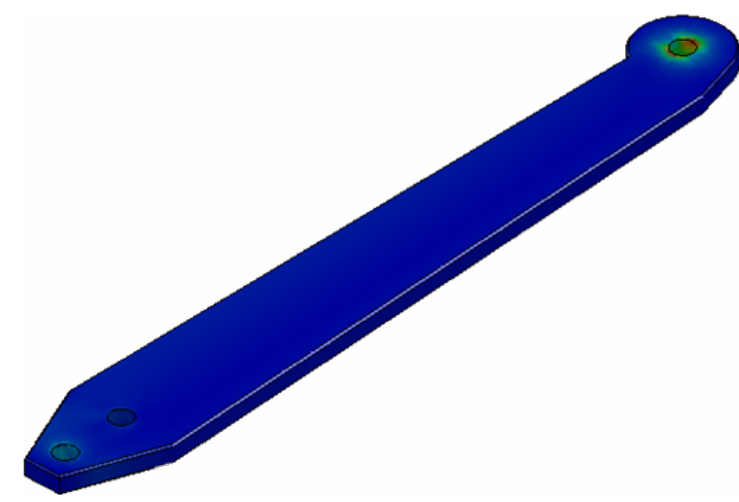

(b)

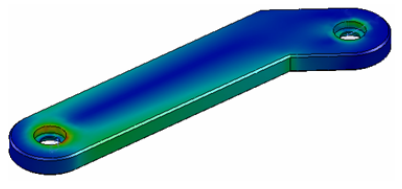

(c)

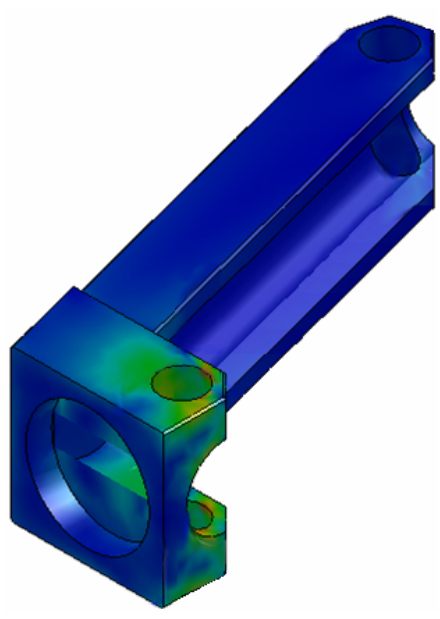

(d)

Figura 3.8: Imagem em escala de cores para as tensões de von Mises para as peças do joelho. (a)Tensões de 0,02MPa a 7,3MPa. (b)Tensões de 0,05MPa a 372MPa. (c)Tensões de 0,13MPa a $65 M P a$. (d)Tensões de $0,02 M P a$ a $53 M P a$.

As tensões apresentadas em todas as peças mostram quais pontos são mais solicitados, por meio da diferença de cores, sendo as regiões com cores mais frias menos solicitadas e as regiões com cores mais quentes mais solicitadas. Nas regiões menos tensionadas, nota-se que pode haver otimizações na geometria, para economizar material e diminuir o peso. Ao contrário, nas regiões de maiores tensões, pode-se trabalhar para aumentar a quantidade de material ou a geometria do componente. No ponto de maior concentração de tensões, estas chegam ao maximo valor de $372 M P a$. Isso significa que, dadas a tensão limite de escoamento do material escolhido - 490MPae as forças aplicadas, pode-se afirmar que todas peças analisadas não falham estaticamente segundo a simulação.

Uma segunda simulação, mais robusta, foi executada utilizando os dados da tabela 3.1, o modelo CAD completo do protótipo - incluindo os elementos de fixação, eixos e embuchamentos - e um elemento 3D do tipo tetraedro. A malha de simulação utilizada - mostrada na figura 3.9 - é composta por 34917 elementos e 60235 nós.

Para essa simulação o pistão MR foi substituído por forças suficientes para manter constante o ângulo do joelho, isso representa mesmo que substituir o pistão por uma barra fixa. Essa 


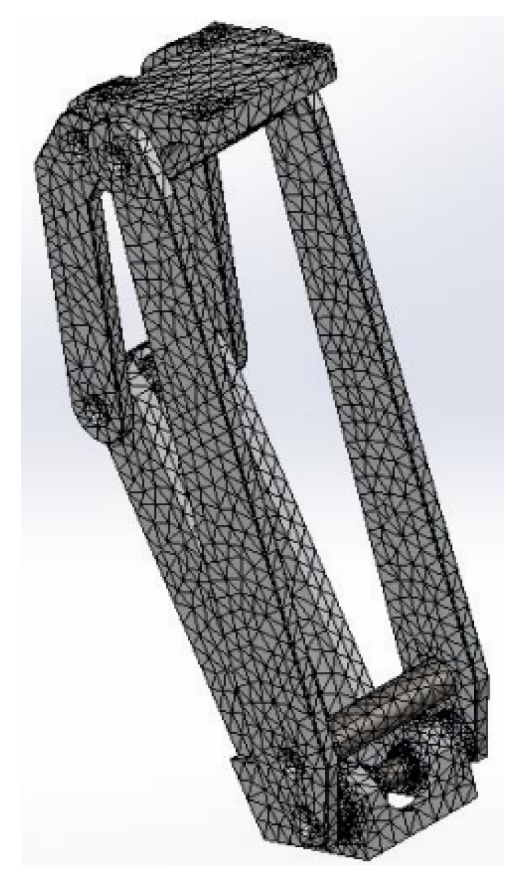

Figura 3.9: Imagem da malha de simulação utilizada pelo software de CAD executar a FEA. Fonte: [1]

simplificação é aceitável dado que nesse estudo não temos interesse avaliar estruturalmente o pistão, mas somente os componentes da estrutura mecânica. A figura 3.10 exibe os resultados da simulação.

A figura 3.10 mostra um como um mapa de calor a distribuição de tensões ao longo da estrutura do protótipo. O maior valor de tensão calculado foi de $64,41 M P a$ no eixo de aço localizado na junta 1, como pode ser visto em detalhe na figura 3.11. Dado que tensão limite de escoamento do material da peça que sofre maior tensão segundo a simulação é $530 M P a$ pode-se afirmar com segurança que prótese não sofrerá falha estrutural em condições normais de operação.

\subsubsection{A junta do joelho}

O joelho desenvolvido foi projetado para apresentar, em extensão total, um CIR posicionado posteriormente à linha de carga a uma distância normal de aproximadamente $15 \mathrm{~mm}$ em relação à referida linha, além de um encurtamento mínimo $10 \mathrm{~mm}$ à flexão de $90^{\circ}$. Esses são valores suficientes para os efeitos desejados de travamento durante a fase de suporte da marcha e de liberação de espaço entre o pé e o chão durante a fase de balanço. As dimensões do atuador escolhido também representava uma limitação às dimensões da estrutura que deveria ser levada em conta.

Depois de diversas simulações, utilizando o equacionamento estabelecido na seção 3.2, no MATLAB e no software de CAD, foi adotado um arranjo de quatro barras que permitiu que as definições tomadas fossem atendidas. As dimensões das barras teóricas ${ }^{7}$ - definidas pelas posições das juntas

\footnotetext{
${ }^{7}$ Barras teóricas são as barras virtuais que ligam os centros de rotação. As barras reais de um mecanismo podem ter diversos comprimentos e formatos, entretanto são as barras teóricas que determinam as distâncias entre os centros de rotação, que, por sua vez, definem o comportamento do mecanismo como um todo.
} 


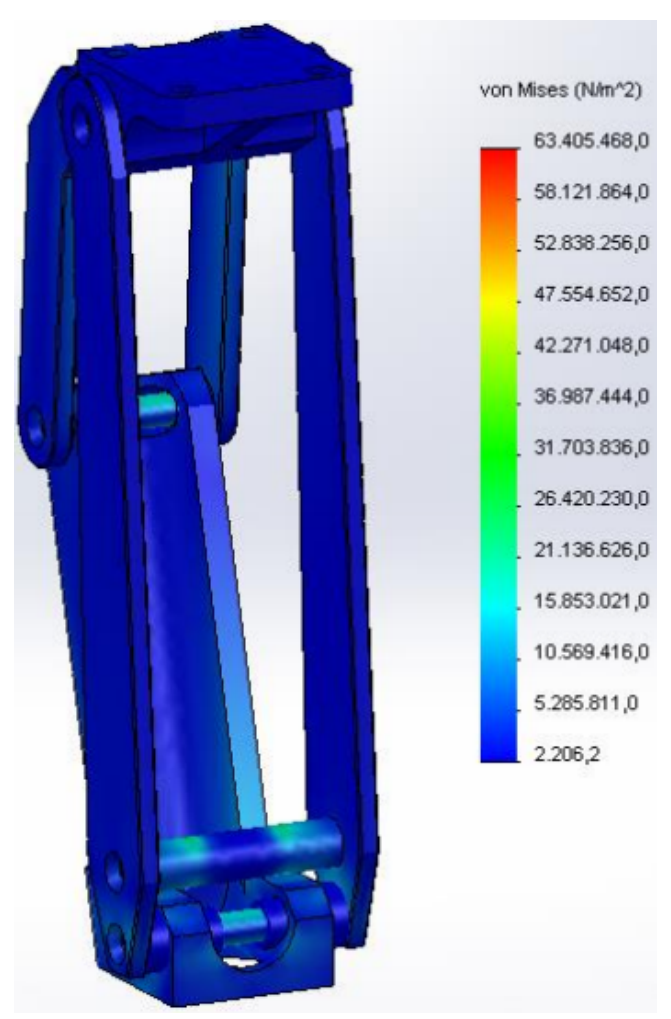

Figura 3.10: Distribuição de tensões ao longo de toda a estrutura do protótipo. Fonte: [1]

rotativas numeradas de 0 a 3 - resultantes das simulações são exibidas na tabela 3.2.

\begin{tabular}{cc}
\hline Juntas & $\begin{array}{c}\text { Distância entre as juntas } \\
\text { (comprimento das barras } \\
\text { teóricas) }\end{array}$ \\
\hline $0-1$ & $197,83 \mathrm{~mm}$ \\
$1-2$ & $125,56 \mathrm{~mm}$ \\
$2-3$ & $85,46 \mathrm{~mm}$ \\
$3-0$ & $22,78 \mathrm{~mm}$ \\
\hline
\end{tabular}

Tabela 3.2: Dimensões das barras teóricas do protótipo.

O deslocamento angular entre as duas juntas entre 0 e 1 - fixas em relação ao soquete - e a horizontal nos eixos coordenados é de $185,04^{\circ}$ e o ângulo acionador $\alpha$ tem valor de $88,61^{\circ} \mathrm{com}$ o joelho extendido. A figura3.12 mostra um desenho em escala das barras teóricas com as com os comprimentos reais das barras do protótipo desenvolvido. 


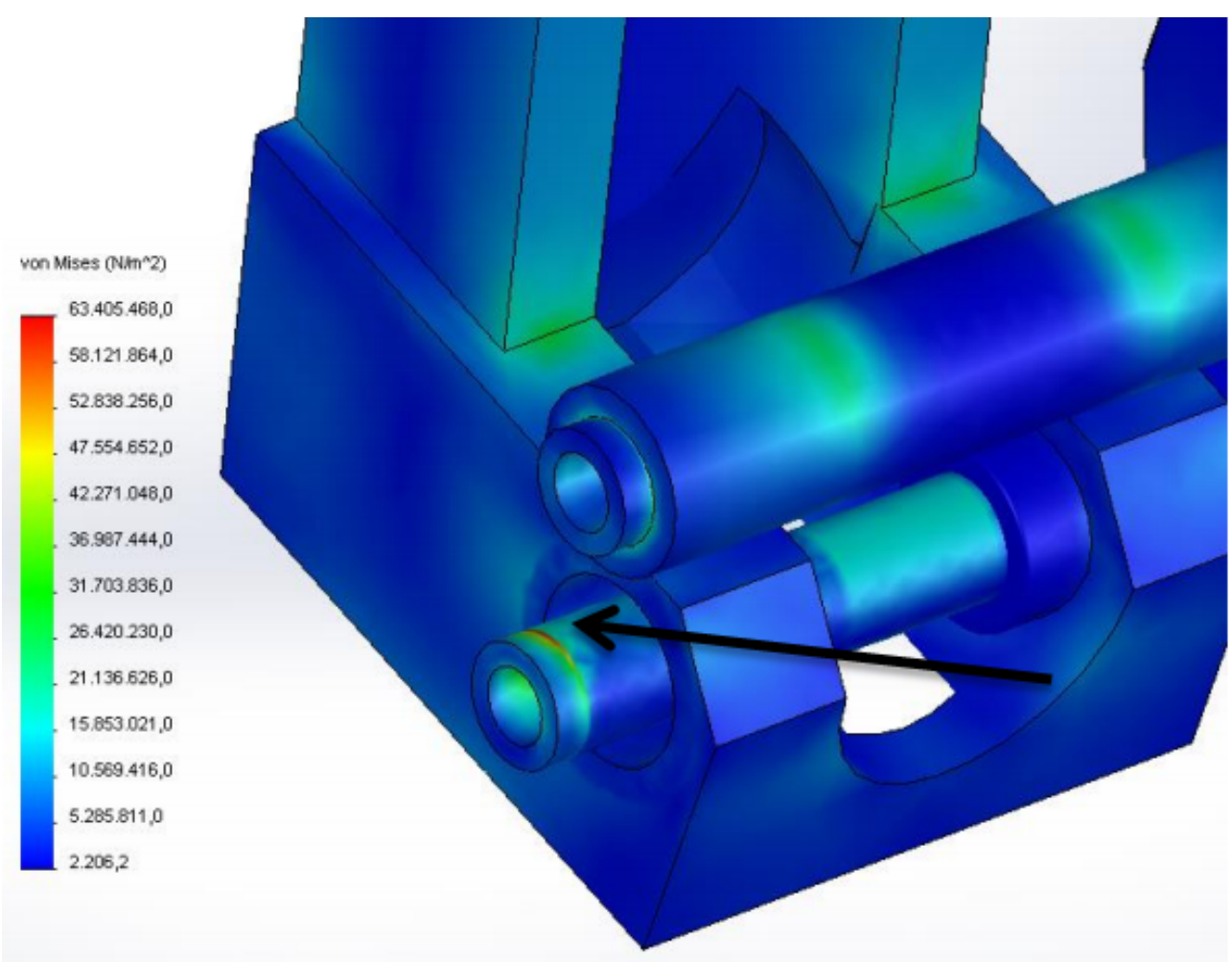

Figura 3.11: Detalhe do ponto de maior concentração de tensões ao longo da estrutura do protótipo. Fonte: [1]

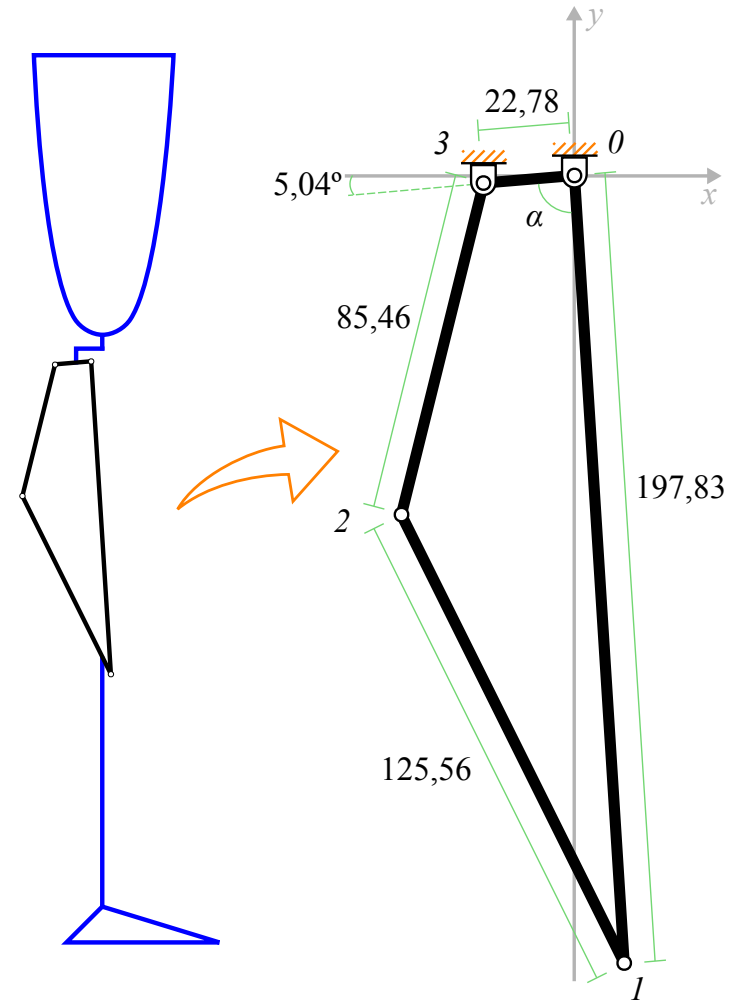

Figura 3.12: Desenho em escala das barras teóricas, suas dimensões e posicionamentos na configuração completamente extendida do joelho, além de uma ilustração exemplificando a prótese completa. As juntas entre as barras são numeradas de 0 a 3 . Na posição totalmente extendida do joelho o ângulo $\alpha$ é igual $88,61^{\circ}$. 
O dispositivo construído é composto de peças mecânicas usinadas em liga de alumínio aeronáutico de alta resistência mecânica e baixo peso específico. As peças são interligadas por parafusos de aço a eixos também de aço que deslizam sobre embuchamentos fabricados em teflon, para a redução do atrito. A confecção foi feita em um centro de usinagem CNC de alta precisão, em virtude a alta especificidade das peças e do alto nível de precisão exigido. A massa total do dispositivo estrutura mecânica e atuador - é $1,620 \mathrm{~kg}$.

Utilizando as equações da seção 3.2 podemos calcular o ângulo do joelho - definido como o ângulo entre as retas suporte da tíbia e do fêmur - para qualquer valor do ângulo acionador $\alpha$. Mais que isso, ainda podemos determinar a trajetória do CIR e encurtamento aparente do dispositivo em função do ângulo $\alpha$. Para o joelho extendido, resolvendo as equações para a posição do CIR em relação a um sistema de coordendas cartesianas centrado no eixo rotacional solidário ao soquete como na figura 3.12 , obtendo a posição $\left(x_{C I R}, y_{C I R}\right)=(-4,54 ; 71,28)[\mathrm{mm}]$. Nesta situação linha de carga está posicionada verticalmente na posição $x_{L C}=10,00 \mathrm{~mm}$, dessa forma, o CIR do joelho na posição extendida está posicionado $14,54 \mathrm{~mm}$ anteriormente à linha de carga. Ilustrando essa situação, a figura 3.13 exibe a dinâmica de movimentação do mecanismo partindo de sua máxima extensão até a máxima flexão em um percurso de $90^{\circ}$ e a trajetória do CIR conforme a variação do ângulo do joelho.

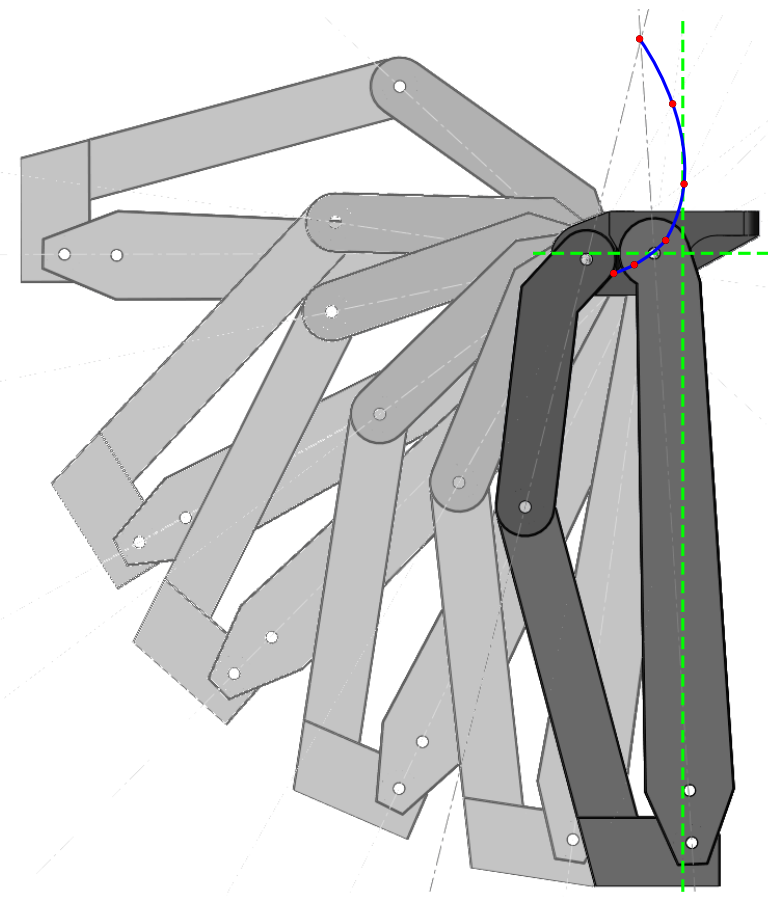

Figura 3.13: Movimentação do mecanismo e evolução do centro instantâneo de rotação em função do ângulo do joelho. A linha azul representa a trajetória do CIR e em verde tracejado estão representadas verticalmente a linha de carga e horizontalmente uma linha passante pelo eixo de rotação da peça superior do mecanismo, solidária ao soquete.

A figura 3.14 ilustra a situação real na qual podemos ver que na fase de apoio a linha de carga - coincidente com a linha entre o trocânter (protuberância óssea na parte superior do fêmur) e o 
tornozelo durante o suporte - está posicionada anteriormente ao CIR. Como visto no capítulo 2 garante maior estabilidade e segurança ao usuário da prótese.

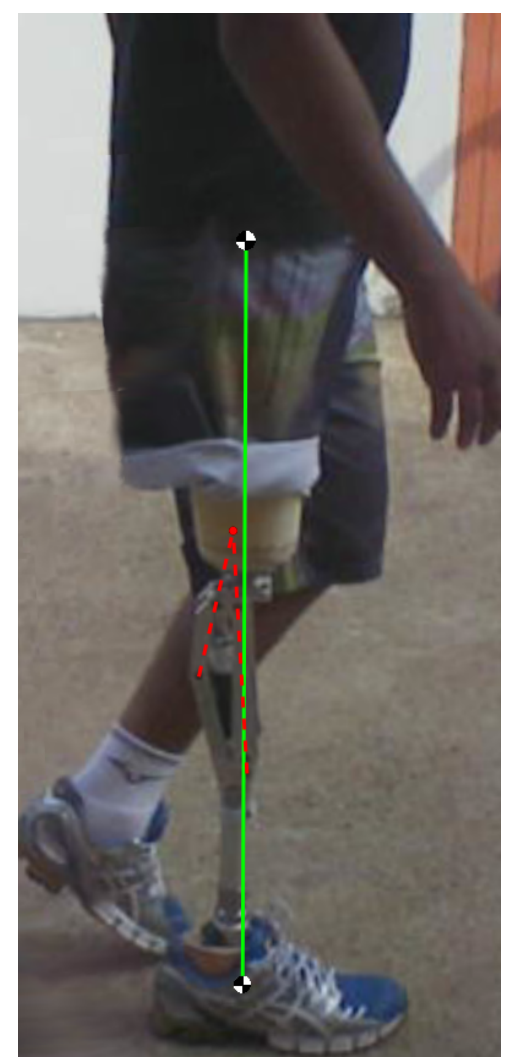

Figura 3.14: Foto de um indivíduo com amputação transfemural utilizando o protótipo. Destaque para o posicionamento da linha de carga (em verde) em relação ao centro instantâneo de rotação (ponto de encontro entre as linhas pontilhadas em vermelho).

Ainda utilizando as equações da seção 3.2 calculamos o encurtamento para todo o percurso da flexão do joelho partindo da posição extendida até a flexão de $90^{\circ}$. O maior valor de encurtamento é de $17,86 \mathrm{~mm}$ à máxima flexão, um valor acima do estabelecido como mínimo. O efeito de considerado especialmente importante para dispositivos que não dispõem de nenhum atuador que promova um dorsiflexão no pé, como é o caso do nosso protótipo. Sem esse, o paciente deveria promover flexão extra no joelho durante o balanço para evitar o choque do pé protético com o solo durante o período final do balanço.

Além respeitar as especificações de posicionamento do CIR e encurtamento, essa configuração de barras permite o encaixe do atuador como mostra em detalhe a figura 3.15, que exibe o mecanismo do joelho em um desenho CAD e no protótipo real, com destaque para as quatro barras teóricas.

Como pode ser visto na figura 3.15 o atuador já está instalado e funciona dentro de sua faixa de operação de $56 \mathrm{~mm}$. 

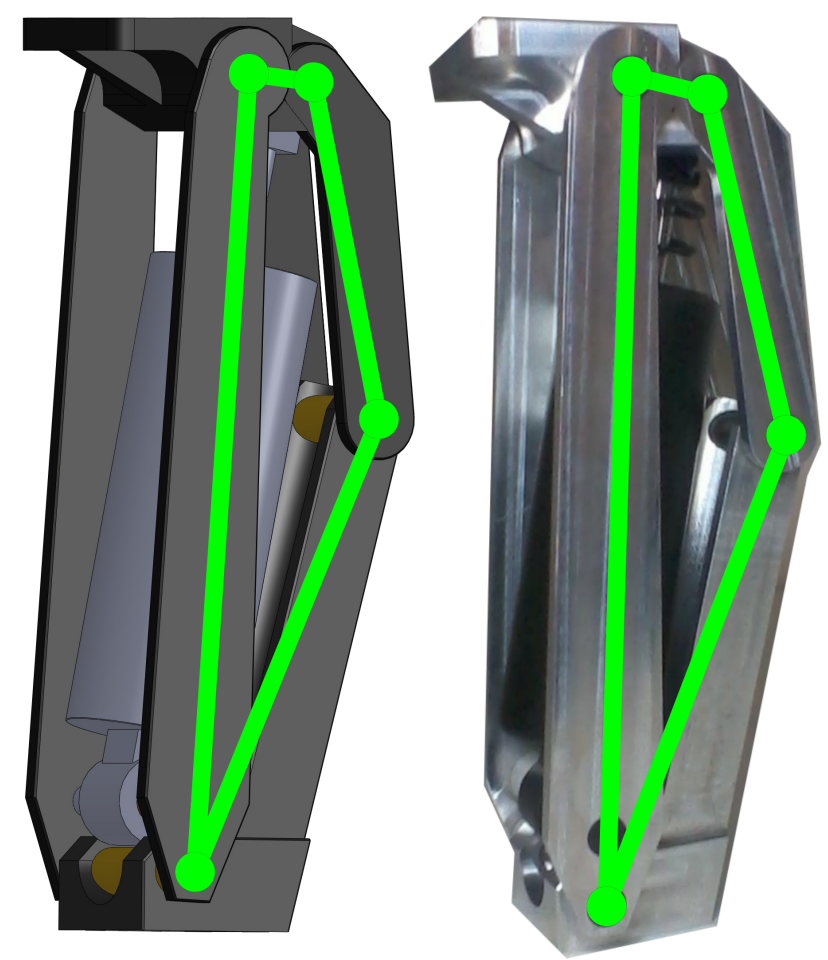

Figura 3.15: Desenho CAD e protótipo real do mecanismo do joelho com destaque para as barras em verde.

\subsection{Atuador magneto-reológico e seu acionamento}

O pistão magneto-reológico LORD ${ }^{\circledR}$ RD-8040-1 utilizado para atuar no mecanismo do joelho, como exposto em termos gerais no capítulo 2, se comporta como um amortecedor com amortecimento controlável por corrente elétrica. Especificamamente, este modelo possui as seguintes características retiradas do datasheet fornecido pelo fabricante: força de amortecimento maior que $2447 N$ à $5 \mathrm{~cm} / \mathrm{s}$ e $1 A$; e força de amortecimento menor que $667 N$ à $20 \mathrm{~cm} / \mathrm{s}$ e $0 A$. A curva característica de amortecimento à baixas velocidades é idêntica à exposta na figrura 2.24 do capítulo 2 . A figura 3.16 mostra uma imagem retirada do datasheet do atuador fornecido pelo fabricante com as dimensões do atuador. 

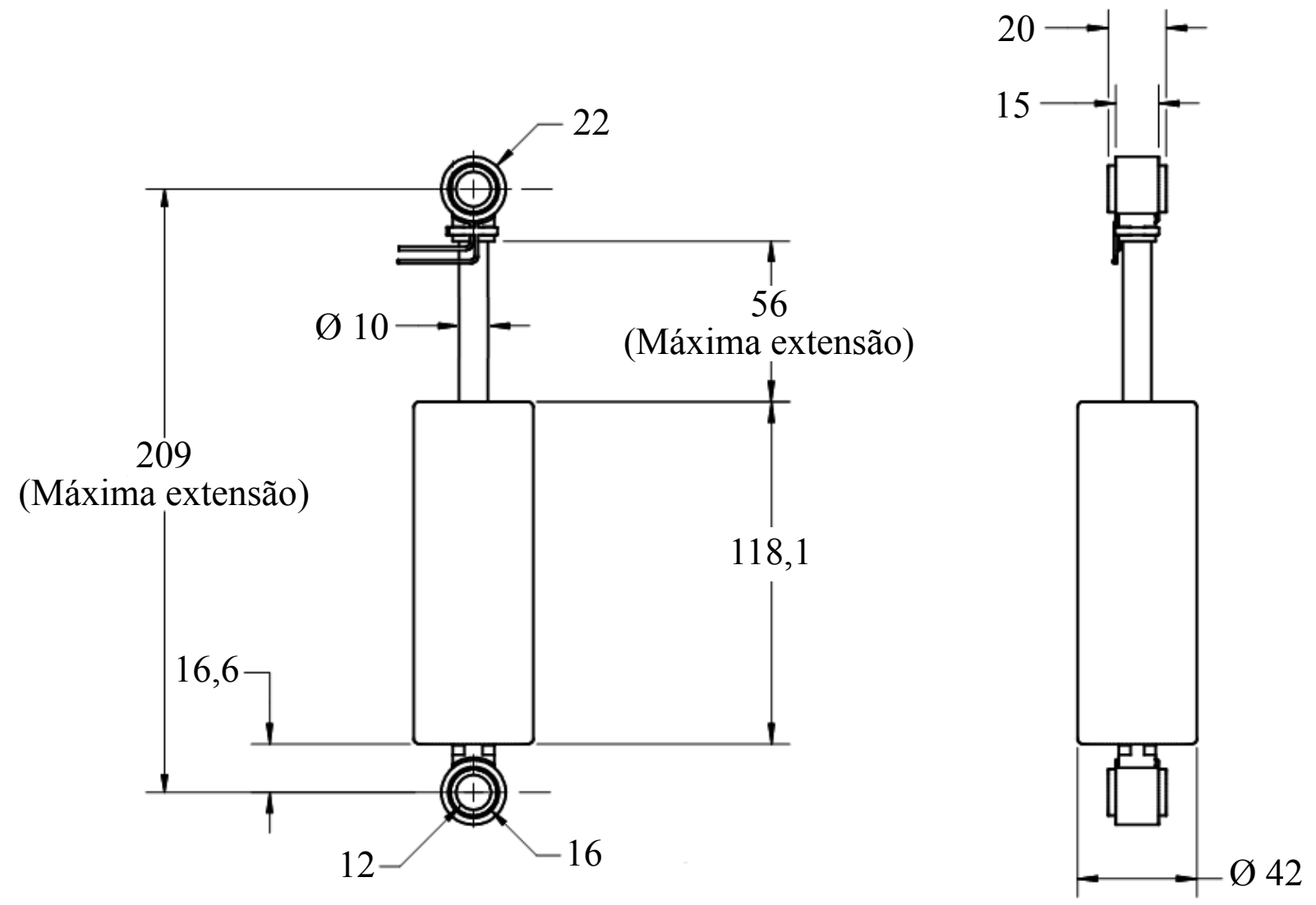

Figura 3.16: Esquemático do pistão MR RD-8040-1, Lord Corporation (dimensões em milímetros). Adaptado de [lord]

O atuador foi montado na estrutura mecânica entre ligando a junta 3 e um ponto sobre a barra entre as juntas 0 e 1 - a $17,51 \mathrm{~mm}$ da junta 1 - como pode ser visto na figura 3.17 . 


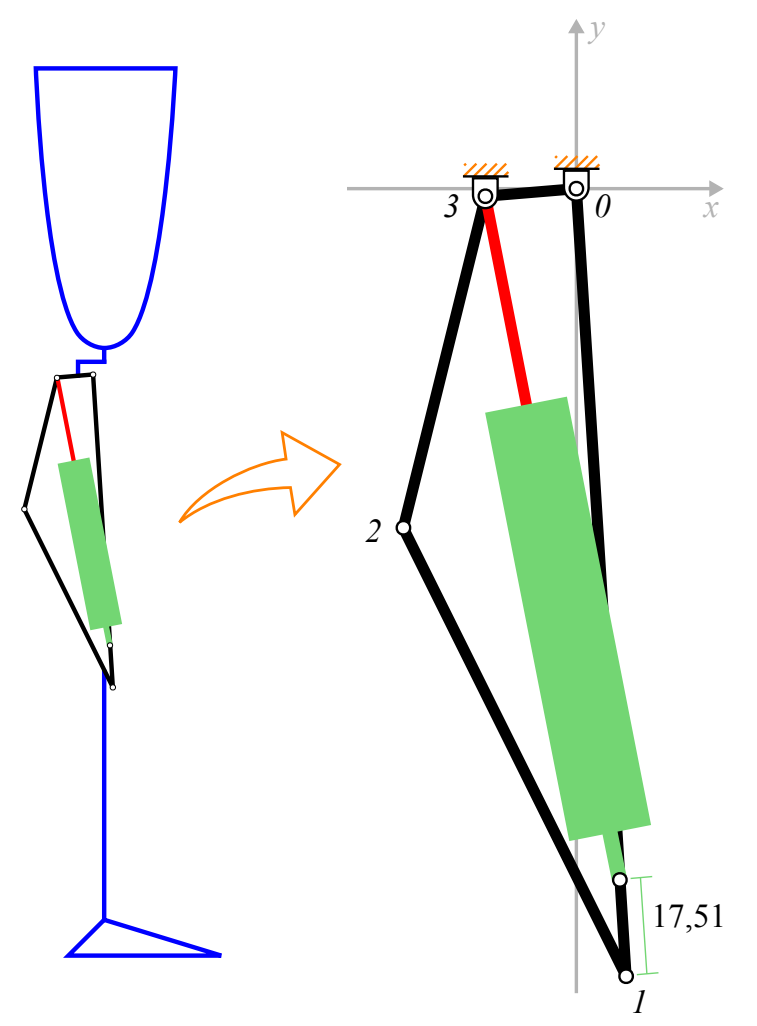

Figura 3.17: Esquemático do posicionamento do pistão na estrutura mecânica.

Neste posicionamento, com o joelho totalmente extendido, o comprimento total do pistão é de $181,26 \mathrm{~mm}$, resultando em um comprimento externo da haste do pistão de $28,26 \mathrm{~mm}$. O comprimento total do pistão se reduz conforme o joelho se flexiona chegando ao valor mínimo de $157,57 \mathrm{~mm}$, resultando em um comprimento externo da haste do pistão de $4,57 \mathrm{~mm}$. Dado que o comprimento externo máximo da haste do pistão é de $56 \mathrm{~mm}$, os valores reais estão dentro da faixa de operação. O comprimento do pistão é função do ângulo $\alpha$ da junta 0 e, utilizando a lei dos cossenos, é determinado pela equação:

$$
c(\alpha)=\sqrt{33034,23-8215,38 \alpha}
$$

Onde $c$ representa o comprimento total do pistão e $\alpha$ variano intervalo $\left[-2,97^{\circ} ; 88,61^{\circ}\right]$, da máxima flexão à máxima extensão.

Segundo o datasheet do pistão MR, do ponto de vista elétrico, ele equivale a uma carga resistiva variável entre $5 \Omega$ e $7 \Omega$ dependendo da temperatura de operção. Essa informaçação foi confirmada em testes de bancada. A especificação de alimentação é com uma corrente de até $1 A$ em modo contínuo ou até $2 A$ de modo intermitente, ou seja, a fonte de alimentação do pistão deve ser capaz de fornecer até $14 \mathrm{~V}$ de tensão e $2 \mathrm{~A}$ de corrente. Em geral, os microprocessadores de sistemas embarcados como o de uma prótese não são capazes de suprir toda essa demanda de tensão e corrente. Assim se fazem necessário o uso de drivers de potência, que são dispositvos que recebem um sinal de referência - nesse caso, vindo do microprocessador - e conseguem entregar à carga a potência necessária para o seu acionamento. Dessa forma, o sistema embarcado da prótese envia 
comandos ao driver de potência que então aplica no pistão a corrente necessária para o nível de amortecimento desejado no joelho de acordo com o algoritmo de controle.

No protótipo descrito neste trabalho utilizamos o driver de potência TB6612FNG, fabricado pela Toshiba. O driver recebe uma sinal pulsado (PWM) como entrada de controle e é capaz de prover até $15 \mathrm{~V}$ de tensão e até $3,2 \mathrm{~A}$ de corrente, sendo bastante suficiente para o consumo máximo de $28 W$ da prótese.

\subsection{Sistema embarcado e sensores}

O sistema embarcado da prótese ${ }^{8}$ consiste principamente de uma unidade computacional Teensy 3.0, fabricado pela PJRC, um microprocessador baseado na arquitetura ARM de alta capacidade de processamento $(48 \mathrm{MHz})$, que recebe os sinais dos sensores e envia comandos para o atuador da prótese. O microprocessador possui três portas UART, uma $\mathrm{I}^{2} \mathrm{C}$ e uma SPI para comunicação com os periféricos.

Interfaceados diretamente com o microprocessador, a prótese conta com dois sensores: uma central inercial e um enconder absoluto. A central inercial é composta de um acelerômetro ADXL345, um giroscópio ITG3200 e um magnetômetro HMC5583, cada efetuando medidas em três eixos direcionais, fabricados respectivamente pela Analog Devices, InvenSense e Texas Instruments. Ela é utilizada para de detecção dos eventos da marcha a partir das medidas de posição e orientação espaciais da próteses e da deteç̧ão de choques mecânicos. O encoder absoluto AMT203, fabricado pela CUI Inc, é utilizado para fazer diretamente a medida do ângulo $\alpha$ da figura 3.12 determinado como unidade acionadora. A ação conjunta desses dois sensores provê ao sistema computacional medidas para a estimação do estado da prótese em marcha com bastante precisão dada a alta resolução digital dos mesmos: 13 bits para central inercial e 12 bits para o encoder.

As medidas obtidas pelos sensores são armazenadas em um cartão de mémoria microSD instalado na prótese além de serem enviadas a um computador por meio de um módulo de transmissão sem fio XBee, da Digi International. Essa coleta de dados tem proósitos de interesse da pesquisa para melhor desenvolvimento do algoritmo de controle. Em uso corrente não há necessidade dessa aquisição pois a prótese é autônoma. Uma bateria lítio-polímero de $1450 \mathrm{mAh} / 11,1 \mathrm{~V}$ alimenta o sistema todo, incluindo o atuador.

A massa somada do sistema embarcado - eletrônica, sensores, bateria e cabeamento - é 0, $326 \mathrm{~kg}$.

A figura 3.18 exibe o sistema embarcado da prótese separado em subsistemas para melhor visualização, além de sua colocação na prótese.

${ }^{8} \mathrm{O}$ sistema embarcado utilizado na prótese é um sistema de propósito geral desenvolvido em outro trabalho do Laboratório de Automação e Robótica do Departamento de Engenharia Elétrica da Univerisidade de Brasília, mesmo laboratório onde foi executado o presente trabalho. 


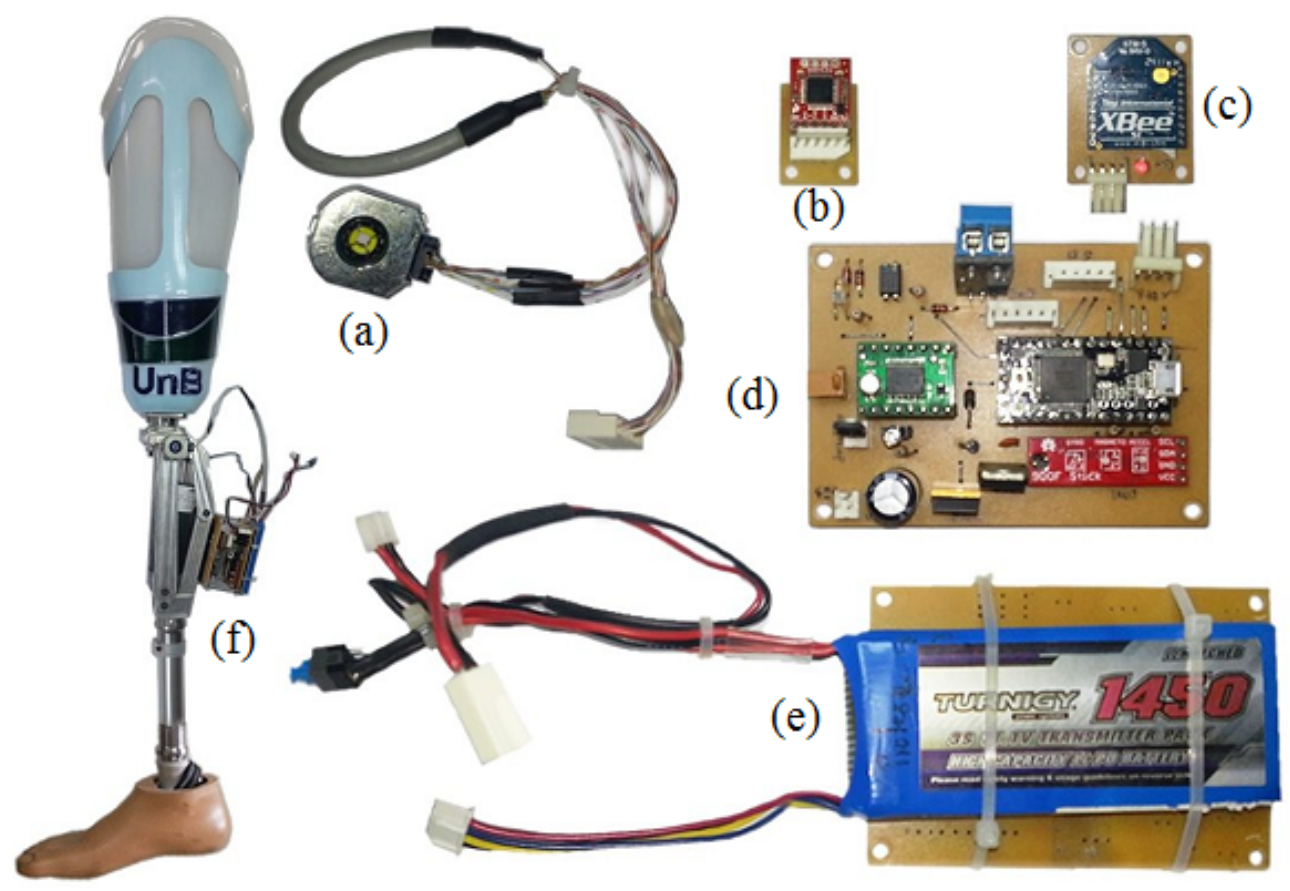

Figura 3.18: Sistema embarcado da prótese. (a) Encoder; (b) Leitor do cartão de memória; (c) Módulo de transmissão sem fio; (d) Placa principal contendo a unidade computacional, o driver de potência, a central inercial e os circuitos de condicionamento de sinal; (e) Bateria; (f) Colocação do sistema embarcado na prótese. 


\section{Capítulo 4}

\section{Avaliação Experimental}

O presente capítulo apresenta as avaliações experimentais do protótipo feitas com o auxílio de um voluntário amputado. O protótipo de prótese transfemural construído passou por testes de verificação de sua funcionalidade em ambientes controlado e não-controlado. O voluntário, já previamente usuário de uma prótese transfemural comercial, foi capaz de perfazer as atividades com as quais estava habituado com o uso de sua prótese.

Utilizando um sistema óptico de captura de movimento avaliamos a movimentação do dispositivo e comparamos as infomações dos sensores embarcados.

\subsection{Prótese em modo passivo}

Assim que finalizada a confecção do conjunto mecânico do protótipo e acoplado a atuador, foi feita a protetização do voluntário amputado ${ }^{1}$, antes mesmo da implantação dos subsistemas embarcados. O voluntário amputado participante desse trabalho é um sujeito do sexo masculino, 35 anos, 1, $85 \mathrm{~m}$ de estatura, $80 \mathrm{~kg}$ de massa, amputado unilateral por 13 anos. O voluntário utiliza um joelho protético 3R80 da Ottobock nas suas atividades diárias. O objetivo deste primeiro experimento foi verificar a movimentação do usuário com a prótese, além de permitir ao voluntário uma avaliação, ainda que qualitativa, do prótese em uso.

De antemão, já era conhecido o comportamento reativo do dispositvo, dado o efeito do acumulador do atuador. Aliado a isso, existe o fato de o pistão já estar pré-comprimido na sua montagem na prótese já na posição extendida, visto que nessa posição o comprimento externo da haste do pistão é de $28,26 \mathrm{~mm}$ ao contrário dos $56 \mathrm{~mm}$ para um pistão livre de carga, conforme visto no capítulo 3. Dessa forma, o viés de pressão acaba por exibir um valor ainda mais alto.

O experimento consistiu em fazer com que o voluntário caminhasse em um terreno plano por cerca de $15 \mathrm{~m}$ repetidas vezes, utilizando o dispositivo em modo passivo, ou seja, sem nenhum

\footnotetext{
${ }^{1}$ Este experimento, assim como todos os outros experitmentos executados no âmbito desse trabalho, foram aprovados pelo comitê de ética da Faculdade de Ciências da Saúde da Universidade de Brasília (protocolo de a provação 079/09 de 18/11/2009).
} 
acionamento do atuador. Não foram feitas dadas nenhuma orientção à respeito da velocidade que ele deveria perfazer sua marcha, apenas foi pedido que ele caminhasse na velocidade que se sentisse confortável. A figura 4.1 mostra o paciente caminhando com a prótese.

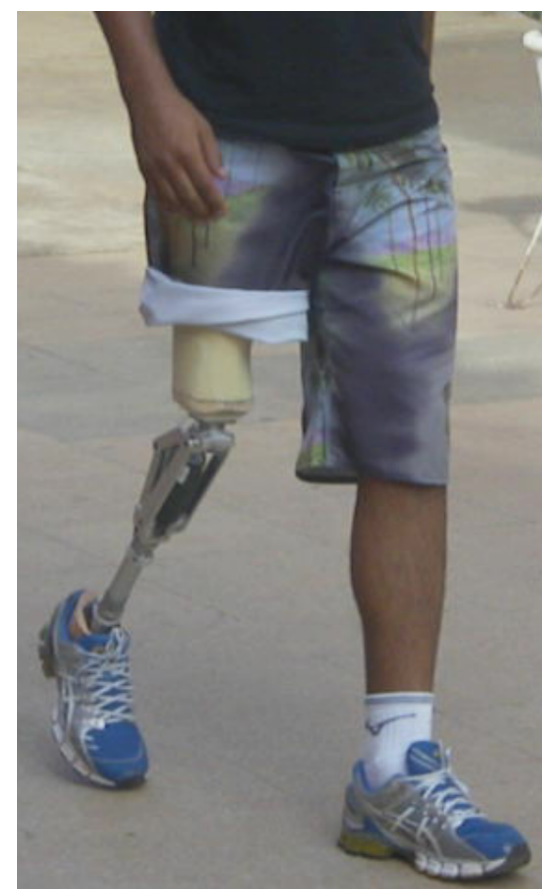

Figura 4.1: Fotografia de voluntário amputado caminhando com a prótese em modo passivo.

Cada percurso de $15 \mathrm{~m}$ executado pelo voluntário foi gravado em vídeo do qual a fotografia da figura 4.1 foi retirada. Uma análise quadro a quadro do vídeo permitiu uma estimativa dos instantes das ocorrências das diversas fases da marcha. Os instantes de contato inicial da perna protética com o solo foram, então, utilizados para o cálculo da estimativa da velocidade desenvolvida pelo voluntário que foi em média de 0,86 passadas/s. A literatura mostra que a passada de indíviduos do sexo masculino sem amputação é em média de 1 passada/s[63], o que mostra que o protótipo desenvolvido induz uma marcha ligeiramente mais lenta que a de um indivíduo sem amputação.

Qualitativamente a impressão dada pelo voluntário era de que a prótese promovia um caminhar tão seguro e confortável quanto a prótese passiva que ele habitualmente usa, exceto pela alta velocidade que ela promove, principalmente de extensão, caracterizado pelo visível "chute" que o dispositivo apresenta no final da fase de balanço. Nesse ponto do ciclo de marcha, a perna (natural ou protética) está sendo lançada a frente pela movimentação da coxa. Soma-se a isso força que o pistão exerce no sentido de voltar à sua posição original dado o efeito do acmulador que está comprimido. O refererido "chute" é, conseqüentemente, o resultado dessas duas forças - inércia da perna e força do acumulador - agindo no sentido de extender o joelho. Esse "chute" é uma ocorrência que deve ser certamente evitada, pois além de possivelmete danosa ao dispositvo por se tratar de choque constante, ela é bastante desconfortável para o usuário.

De fato, essa característica notada em modo passivo, mostra-se desejável visto que atuador tem a principal propriedade de reduzir a velocidade do dispositivo. Em modo ativo podemos efetivamente controlar a velocidade da prótese acionando o atuador de forma a reduzí-la nos instantes 
finais do ciclo de marcha evitando o "chute".

\subsection{Prótese em modo controle manual}

Ainda na mesma bateria de testes preliminares, antes da implantação dos subsistemas embarcados, executamos um experimento com a prótese em modo ativo. Nesse segundo momento o voluntário caminhou continuamente sobre uma esteira ergométrica à velocidade de $80 \mathrm{~m} / \mathrm{s}^{2}$. O atuador da prótese foi ligado a um controlador de corrente, com um nível de corrente aplicada ajustada manualmente através de um potenciômetro conforme o voluntário caminhava. A figura 4.2 retrata essa situação.

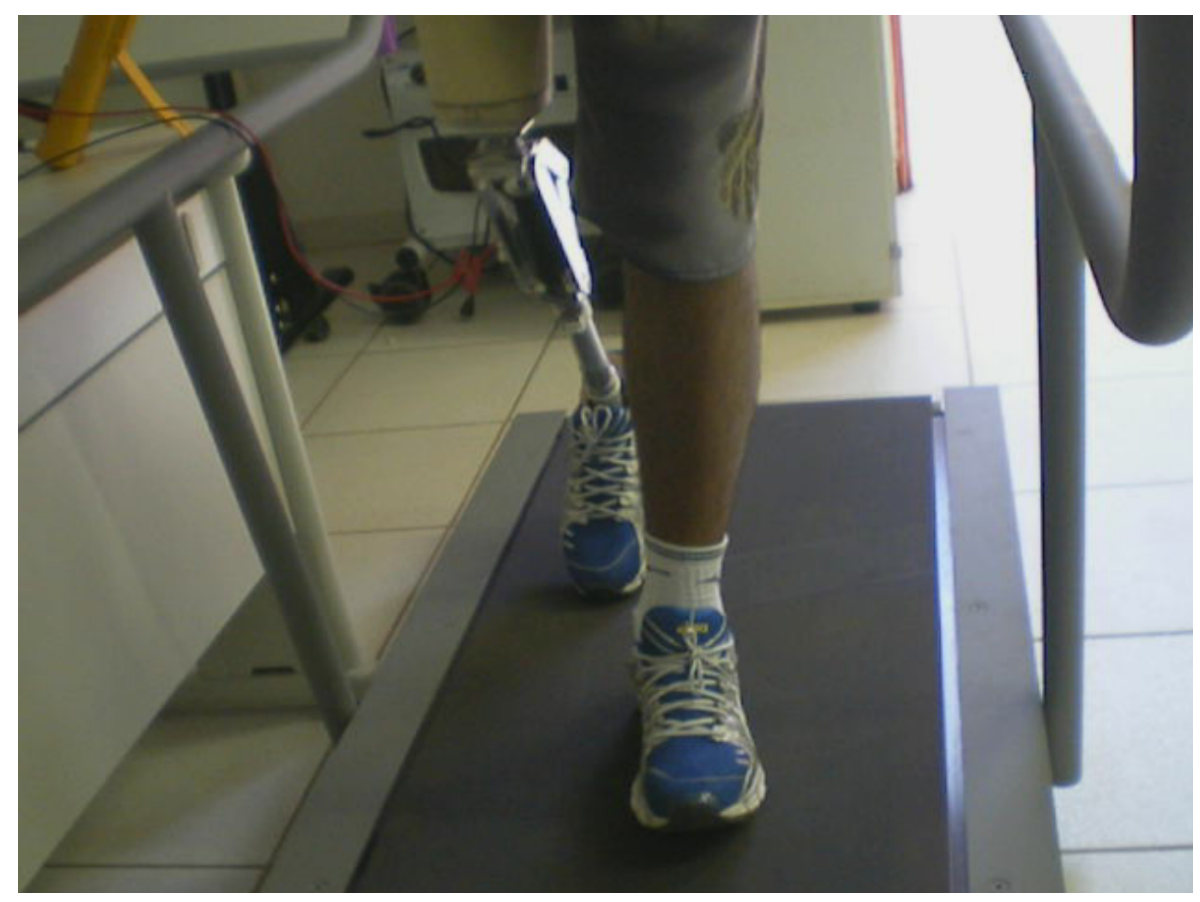

Figura 4.2: Voluntário caminhando em uma esteira com a prótese em modo controle manual.

Apesar das claras limitações de um experimento com controle manual em tempo real como esse, foi possível observar uma maior naturalidade e conforto no caminhar do voluntário, que chegava a referir como "perfeito" determinados momentos do experimento. A principal contribuição desse experimento foi um melhor entendimento de como deveria atuar o controlador automático da prótese. Foi observado que o controle da velocidade de extensão do joelho na fase final do balanço é crucial para a qualidade da marcha do usuário. Essa observação é sustentada pela análise teórica da marcha humana vista na subseção 2.1.1.1. Como visto, entre os 90 e $100 \%$ do ciclo de marcha, o sistema muscular trabalha para aumentar a rigidez do joelho, preparando para a recepção do peso. O atuador da prótese então deve ser acionado para agir de maneira semelhante, aumentando a rigidez do movimento do joelho através do aumento da corrente de controle do pistão.

Para além disso, os experimentos preliminares executados, mesmo que bem simples e de caráter

\footnotetext{
${ }^{2}$ Velocidade de média de indivíduo sem amputação de acordo com a literatura[63].
} 
apenas qualitativo, demonstram o potencial de uso e segurança da prótese ainda em modo passivo. Isso representa um requisito importante visto que em caso de pane nos sistema embarcado, a prótese se comporta no mínimo como uma prótese passiva convencional. Em se tratando de sistemas embarcados panes são eventos que devem ser sempre tratados como passíveis de ocorrência - e efetivamente ocorrem pelos mais diversos motivos, desde uma simples falta de energia, até um defeito em componente eletrônico -. Nesses momentos o dispositivo deve ser robusto o suficiente para garantir condições mínimas de segurança ao usuário.

\subsection{Captura de movimento}

Utilizando o sistema Qualisys de captura de movimento, executamos um terceiro experimento para avaliar a movimentação da prótese em tempo real e tomar medidas biomecânicas durante a marcha. O sistema em questão, utiliza-se de marcadores ópticos posicionados em diversas posições no corpo e na prótese do voluntário que são detectados por um conjunto de câmeras especiais posicionadas de forma a captar em diferentes ângulos da região de interesse no espaço. As imagens são processadas pelo software do sistema que então constrói um modelo espacial interativo dos marcadores. A figura 4.3 mostra o voluntário amputado utilizando a prótese durante o experimento. Nela também é possível ver a posição dos marcadores

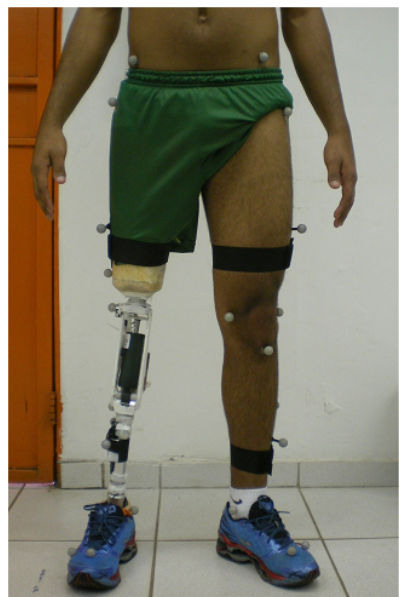

(a)

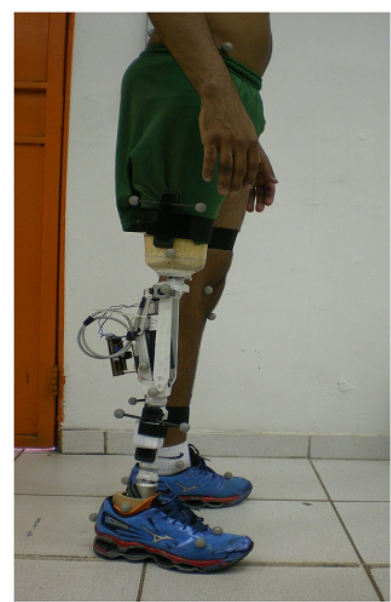

(b)

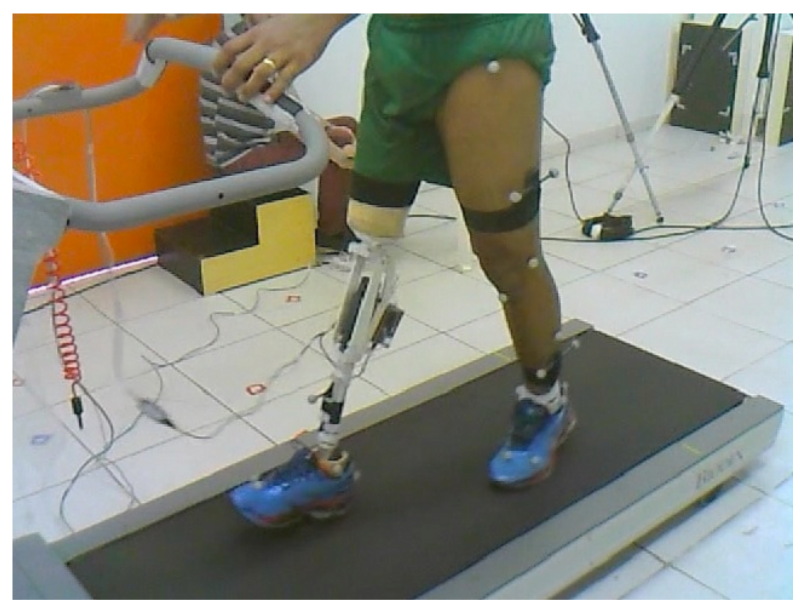

(c)

Figura 4.3: Voluntário durante o experimento de captura de movimento. (a) Estático em vista frontal; (b) Estático em vista lateral; (c) Voluntário caminhando em uma esteira com a prótese em modo de identificação. Fonte: [64]

Neste experimento, o voluntário caminhou à velocidade de $80 \mathrm{~m} / \mathrm{min}$ em uma esteira enquanto o sistema de captura de movimento e os sensores da prótese geravam dados sobre a marcha do voluntário. O dois principais objetivos deste experimento foram estudar e descrever a marcha do indivíduo em termos cinemáticos, e identificar na marcha do indivíduo os eventos caracterizantes da marcha. Baseado no padrão de marcha desenvolvido pelo voluntário e nos instantes de ocorrência dos eventos é possível acionar o atuador corretamente buscando promover a marcha da forma mais 
natural possível, ou seja, controlar o atuador.

O primeiro resultado do experimento pode ser visto na figura 4.4. Ela exibe, dentro de um ciclo de marcha, um gráfico comparativo entre os ângulos do joelho de um indivíduo sem amputação (laranja tracejado), do joelho intacto do voluntário (verde) e do joelho protético em modo passivo (azul), todos obtidos com o sistema de captura de movimento.

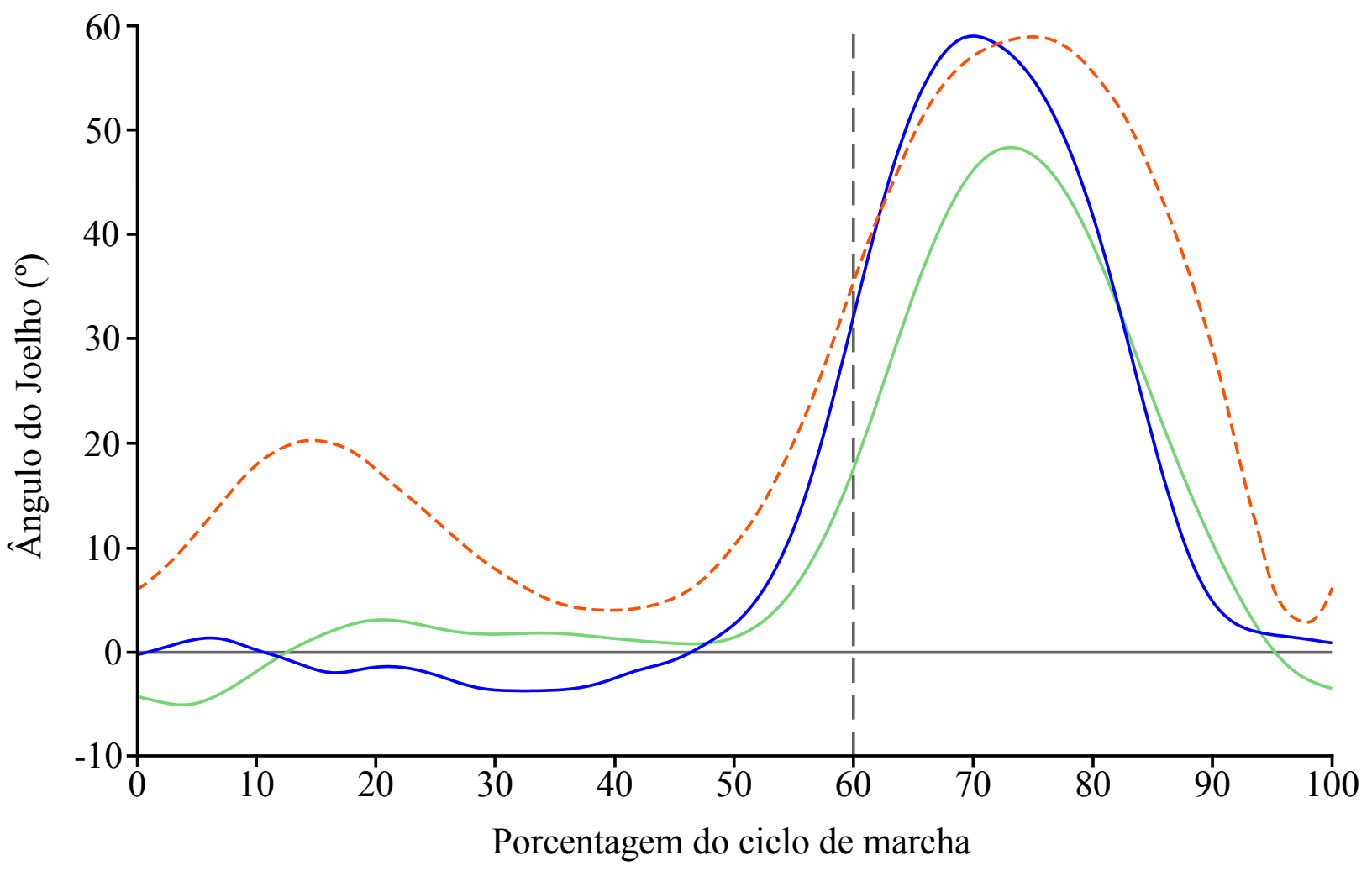

Figura 4.4: Variação angular comparada entre joelho de indivíduo sem amputação (laranja tracejado), joelho protético em modo passivo (azul) e joelho saudável de indivíduo amputado (verde) durante um ciclo de marcha.

Pela figura 4.4, pode se ver que além do fato do joelho protético não ser capaz de realizar a flexão do joelho no início do ciclo de marcha (0-30\%), como já estabelecido na seção 2.2.4 do capítulo 2 , chama a atenção a semelhança entre as curvas do joelho intacto e do joelho protético do voluntário. Vê-se que mesmo o joelho intacto não realiza a flexão do joelho no início do ciclo de marcha, no que parece ser um mecanismo desenvolvido pelo amputado em compensação ao movimento da prótese da perna amputada, apesar de não ter sido realizado nenhum estudo aprofundado sobre esse efeito.

Nota-se também que o movimento de balanço das pernas tanto da intacta quanto da protética do voluntário ocorre mais rapidamente que de um indivíduo sem amputação. Como observado no experimento da seção 4.1, a prótese em modo passivo não possui nenhum mecanismo que promova o controle da velocidade da extensão, resultando no já mencionado "chute". A grosso modo, podemos dizer que o ciclo de marcha da prótese é mais curto que o ciclo de marcha do usuário, como pode-se notar que a curva da prótese chega ao muito próxima ao seu valor final do ciclo a aproximadamente $90 \%$ do ciclo de marcha. Quanto ao membro intacto, novamente indica 
um mecanismo conpensatório do voluntário em busca de uma melhor simetria com os movimentos da perna protética.

Essas duas observações sugerem fortemente que a aplicação de um amortecimento tanto no primeiros $30 \%$ do ciclo de marcha quanto nos últimos $20 \%$ pode tornar o movimento da prótese mais semelhantes ao movimento natural. O amortecimento na fase do suporte possibilitaria ao usuário deixar seu própro peso corporal promover a flexão de maneira controlada e segura, facilitando a recepção do peso. Na fase do balanço, o amortecimento promoveria uma extensão mais suave evitando o "chute".

O segundo resultado do experimento está retratado na figura 4.5que mostra gráficos obtidos com o sistema de captura da movimento e com os sensores da prótese para o ângulo, velocidade e aceleração do joelho protético em três ciclos de marcha consecutivos. 


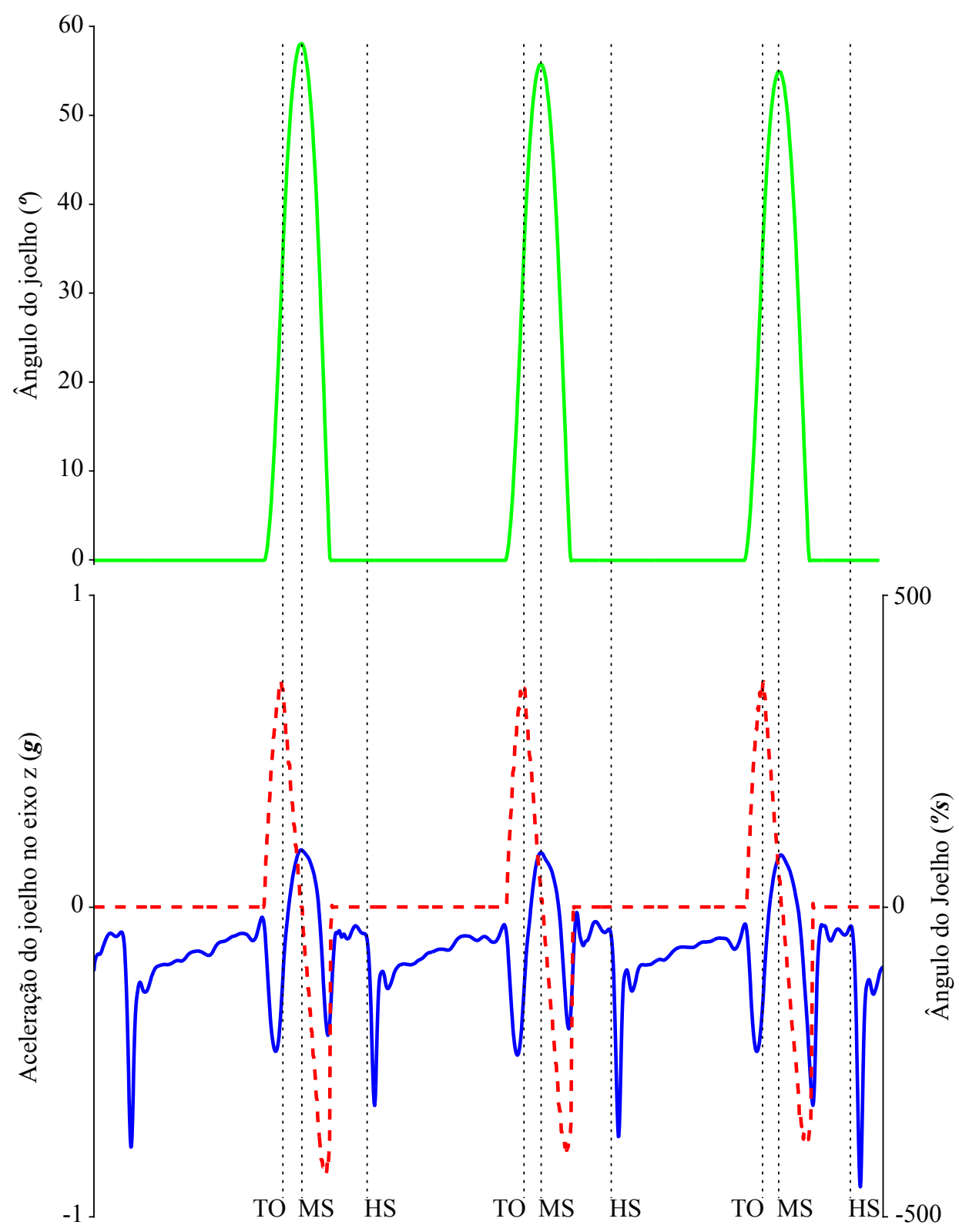

Figura 4.5: Variação angular (verde), velocidade angular (vermelho tracejado) e aceleração angular (azul) do joelho protético em três ciclos de marcha consecutivos. Destaque para instantes de ocorrência dos eventos da marcha (linhas pretas tracejadas). Fonte: [64].

Os dados utilizados para a construção dos gráficos da figura 4.5 foram obtidos a partir das leituras do encoder - para a variação angular em verde - e da central inercial - para a velocidade angular, vermelho tracejado, e para a aceleração angular em azul -. Utilizando a nomenclatura estabelecida na seção 2.1, nota-se pelo gráfico de variação angular da figura 4.5 os momentos da ocorrência da fase de MS caracterizada pela inversão do sentido da curva. Ou seja, o joelho que até esse instante do ciclo de marcha estava flexionando, começa a extender em virtude da perna que está sendo lançada à frente.

Da mesma maneira, porém agora observando o gráfico de velocidade, podemos destacar os momentos em que ocorrem a fase de TO também caracterizada pela mudança no sentido da curva 
quando ela atinge seus máximos locais. Nesse momento a perna continua flexionando por um momento até o MS mas em desaceleração a partir do exato momento que a prótese dá seu último impluso à frente e retira totalmente o pé do chão.

A ocorrência do evento de HS, entretanto, não é trivial de ser estimada apenas pelas leitura dos sensores da prótese, foi preciso utilizar a posição de um marcador posicionado no calcanhar da prótese e observar seus instantes de maior proximidade com o chão para identificar os instantes de o corrência do HS. Muito embora um algoritmo mais refinado de detecção de eventos seja capaz de identificar a ocorrência do HS, dada a previsibilidade do sinal do acelerômetro como visto no gráfico. Os instantes de ocorrência dos eventos caracterizantes estão marcados nos gráficos pela linhas pretas tracejadas. 


\section{Capítulo 5}

\section{Conclusões e Trabalhos Futuros}

\subsection{Conclusões acerca do trabalho}

Estudos mostram que o uso de próteses robóticas por indivíduos com amputação de membro inferior pode aumentar consideravelmente o benefício funcional do dispositivo [31, 34, 35, 38, 43]. O presente trabalho apresentou e descreveu a construção de uma prótese transfemural robótica - em especial o projeto mecânico e seu sistema de atuação -, bem como o arcabouço teórico necessário à compreensão do projeto.

\subsubsection{Estutura mecânica}

O dispositivo foi desenvolvido com base em um mecanismo de quatro barras que apresenta as vantagens funcionais de posicionamento conveniente do centro instantâneo de rotação, em especial durante a fase de suporte da marcha, e de encurtamento aparente do comprimento total do dispositivo duarnte a fase de balanço. Como foi visto, o posicionamento do centro instantâneo de rotação do joelho protético posteriormente à linha de carga do indivíduo usuário do dispositivo leva ao bloqueio da movimentação do joelho sem a necessidade de esforço muscular. Ao mesmo tempo que o encurtamento libera mais espaço com a superfície para a passagem da perna em balanço.

Existem claramente outros métodos para realizar o travamento da rotação do joelho totalmente estendido, como por exemplo alinhando a protése de modo que o joelho hiperextenda exatamente como se faz para garantir o travamento em joelhos monocêntricos -, estretanto o efeito cosmético de uma prótese alinhada de maneira similar ao joelho normal e o efeito funcional de uma melhor simetria com a perna sadia, justificam a estratégia de posicionamento conveniente do centro instantâneo de rotação do dispositivo de quatro barras. De fato, o alinhamento do joelho monocêntrico dá ao membro protético uma aparência semelhante ao de uma deformidade do joelho conhecida como genu recurvatum, ou joelho curvo, na qual o joelho apresenta uma hiperextensão exagerada[5], o que clarmente afeta do ponto de vista estético o usuário.

Ainda que a liberação de espaço entre a prótese em balanço seja de somente alguns poucos milímetros entre o pé e a superfície, esse é suficiente para evitar que o usuário necessite promover 
esforço adicional para evitar o choque entre o pé e a superfície durante o balanço intermediário. Ou seja, o usuário evita esforço na articulação do quadril para a suspensão da perna protética.

A simulação numérica do modelo CAD do dispositivo, através da técnica de análise de elementos finitos permitiu verificar a intergridade estrutural do dispositivo em condições normais de operação. Por essa análise a prótese pode ser consderada sergura do ponto de vista estrutural. Para mais que isso, os resultados da simulação sugerem possibilidade de otimização do modelo, que tem uma estrutura bastante conservadora. A retiradada de material da estrutura pode ser feita ser perda de intergridade e acarretará em uma diminuição considerável do peso que, como demonstro neste trabalho, é um fator de suma importância para o conforto do usuário na utilização da prótese. As simulações inclusive abrem espaço para alteração do arranjo de quatro barras em si, como comprimentos das barras e posicionamento relativo dos centros de rotação.

\subsubsection{Atuação e sensores}

O pistão magneto-reológico que atua o dispositivo, um amortecedor com constante de amortecimento variável controlável por corrente elétrica, provou-se suficiente para o atual modelo do dispositivo bem como para os requisitos de esforços esperdos que ele promova e consumo de energia. O acionamento do pistão é controlado por um microcontrolador de baixo consumo que faz a leitura dos sensores instalados na prótese. Os sensores em questão são um encoder absoluto, que mede o ângulo do joelho, e uma central inercial, que toma medidas cinemáticas da prótese.

Apesar de o atuador utilizado não ser capaz de fornecer potência ativa, mas apenas resistiva, para o nível atual de exigência dos requisitos da prótese essa característica dissipativa se mostra suficiente como foi possível ver neste trabalho. O esforço ativo na junta do joelho é dado pelo deslocamento do peso do usuário e da inércia do membro, não sendo necessário esforço ativo adicional na junta do joelho.nao obstante

Há que se considerar a falta de potência ativa advinda da junta do tornozelo da prótese, que como esclarecido é a junta que sofre os maiores esforços ativos, ou seja, o tornozelo é a junta que efetivamente impulsiona o corpo na direção da marcha. O projeto da junta do tornozelo não foi descrito nesse trabalho mas a inclusão dessa junta é de vital importância para a versatilidade em termos de modos de marcha possíveis de execução com essa prótese de maneira confortável ao usuário

\subsubsection{Avaliação experimental}

A avaliação experimental da prótese, executada com o auxílio de um voluntário amputado transfemural, apresenta quatro principais principais resultados: em modo passivo a prótese se comporta com uma prótese convencional, alta velocidade de movimentação da prótese em modo passivo, necessidade de controle da extensão no balanço terminal e capacidade de detecção dos eventos da marcha apenas com sensores de medida angular e de variáveis cinemáticas.

O primeiro resultado se mostra bastante importante pois mesmo em uma situação de pane, o 
usuário seria capaz de utilizar a prótese. Isso representa uma característica de segurança bastante desejável para o usuário. Situações em que a prótese fique sem energia por exemplo, muito comum para a maioria dos dispositivos portáteis, acarretaria em uma limitação da qualidade da marcha, todavia ainda seria possível aos usuário promover marcha de maneira similar à uma prótese convencional passiva, ou seja, no pior caso a prótese projetada tem performance igual a uma prótese convencional.

O segundo resultado sugere que o aumento do amortecimento durante determinados instantes do ciclo de marcha pode dar bons resultados. O aumento global do amortecimento leva a uma diminuição da velocidade total da prótese suavizando a marcha. Como foi visto, a principal tarefa executada pelo joelho é de controle da marcha e ele o faz principalmente com esforços dissipativos, mesmo tipo de esforço promovido pelo atuador.

O que mostra o terceiro resultado é que a performance da prótese pode ser melhorada com a implentação do controlador para acionar o atuador em um momento específico, na extenção total do joelho no final do ciclo de marcha. Isso não significa que não existam outros instantes da marcha nos quais o acionamento do atuador não vá melhorar a performance, haja visto que uma atuação que auxilie o usuário a promover a flexão do joelho na fase de suporte pode também levará a uma melhora de performance. Contudo o controle e a atuação em um único momento já ser capaz de melhorar a performance consideravelmente é bastante animador já que pode ser por exemplo definido um modo de operação do dispositivo que entra em ação em um cenário de baixa de energia e priorize essa ação em detrimento de outras no intuito de economizar energia.

Por fim o último resultado avaliado experimentalmente mostra que três dos eventos característicos da marcha podem ser detectados com os sensores atualmente presentes na prótese. A caracterização desses eventos é subsídio indispensável ao controlador à ser implementado na prótese. Observando os atuais requisitos de marcha para o dispositivo, a detecção desses eventos se mostra suficiente para o correto controle da prótese.

\subsection{Trabalhos futuros}

A prótese transfemural desenvolvida nesse trabalho, apesar de ser funcional, inspira diversas melhorias que são sugestões como trabalhos futuros. Alguns deles são listados a seguir.

1. Projeto e implementação do algoritmo de controle da junta do joelho:

O algoritmo atual desenvolvido pela equipe de trabalho opera de forma rudimentar, ele aciona o atuador em malha aberta em um único instante do ciclo de marcha com um valor fixo de referência, ou seja, um controlador liga-desliga. Acredito que com esses mesmos sensores e atuador disponível é possível desenvolver um controlador em malha fechada que atue em todos os instantes da marcha de acordo com as transições entre os estados;

2. Instalação de sensores capazes de medir os esforços estáticos e dinâmicos da prótese em marcha: 
O projeto já dispõe de duas células de carga de seis graus de liberdade, capazes de medir força e torque tridimensionais, que ainda não foram instalados. A incorporação desses sensores deve aumentar em muito a precisão da detecção dos eventos de marcha tornando o controlador muito mais robusto;

3. Caracterização completa da montagem atuador e mecanismo do ponto vista dos esforços mecânicos envolvidos:

As informações a respeito do atuador utilizadas no trabalho e apresentadas aqui foram todas extraídas do datasheet do fabricante e da literatura, nenhum ensaio de bancada de aplicação do atuador ao dispositivo foi feito. Acredito que a caracterização mecânica completa do atuador aplicado ao dispositivo vai tornar o controle mais fácil e previsível;

4. Finalização e instalação do protótipo transtibial:

O protótipo de junta tornozelo-pé está em processo de fabricação e deve ser incorporado ao joelho. Dessa forma teremos uma prótese transtibial robótica completa, atuada nas duas juntas;

5. Caracterização da prótese transfemural completa, joelho e prótese transtibial:

A mesma caracterização sugerida para a junta do joelho deve ser feita para as duas juntas em conjunto;

6. Projeto e implementação do algoritmo de controle da prótese transfemural completa:

Desenvolvimento do controlador final da prótese robótica transfemural. 


\section{REFERÊNCIAS BIBLIOGRÁFICAS}

[1] SOUSA, F. PROJETO DE TORNOZELO MECÂNICO E AVALIAÇÃO DE JOELHO MECÂNICO PARA AMPUTADOS. 2014.

[2] MOSBY. Mosby's Dictionary of Medicine, Nursing 83 Health Professions. [S.l.]: Elsevier Science Health Science Division, 2009. ISBN 9780323065665.

[3] MURDOCH, G.; BENNETT-WILSON, A. Amputation: Surgical Practice and Patient Management. Taylor \& Francis, 1996. ISBN 9780750608435. Disponível em: $<$ https://books.google.com.br/books?id=PtFsAAAAMAAJ $>$.

[4] OLENDORF, D. et al. The Gale Encyclopedia of Medicine: A-B. [S.l.]: Gale Research, 1999. (The Gale Encyclopedia of Medicine). ISBN 9780787618728.

[5] NEUMANN, D. A. Kinesiology of the Musculoeskeletal System. [S.1.]: Mosby/Elsevier, 2002.

[6] OTTOBOCK. Informações para Amputados. http://www.ottobock.com.br/prosthetics/ informação-para-amputados/da-amputação-a-reabilitação/nível-de-amputação/.

[7] SPICHLER, E. R. S. et al. Capture-recapture method to estimate lower extremity amputation rates in rio de janeiro, brazil. Revista Panamericana de Salud Publica, p. 334-340, 2001.

[8] MCGIMPSEY, G.; BRADFORD, T. Limb Prosthetics Services and Devices Critical Unmet Need: Market Analysis. [S.l.], 2015.

[9] FERREIRA, R. U. et al. Reconhecimento de padrões de sinais de emg para controle de prótese de perna. In: XI Congresso Brasileiro de Biomecânica. [S.l.: s.n.], 2005. p. 1-5.

[10] JÚNIOR CARLOS ALBERTOAND FERREIRA, R. U. C. et al. Estudo e desenvolvimento de uma prótese ativa de perna comandada por sinais eletromiográficos. In: VII Simpósio Brasileiro de Automação Inteligente / II IEEE Latin-American Robotics Symposium. [S.l.: s.n.], 2005. p. 1-8.

[11] JUNIOR, C. A. C. Prótese Mecânica para Reabilitação Robótica. Trabalho de graduação em Eng. de Controle e Automação. 2005.

[12] RODRIGUES, S. d. S. et al. Estudo e desenvolvimento de uma prótese robótica de perna comandada por sinais eletromiográficos. In: IV Congresso Iberdiscap (Red Iberoamericana de Tecnologías de Apoyo a la Discapacidad). [S.1.: s.n.], 2006. p. 1-6. 
[13] BECKMAN, E. D.; SANTOS, G. F. dos. Desenvolvimento de Controladores de Juntas para Prótese Robótica de Perna. Trabalho de graduação em Eng. de Controle e Automação. 2006.

[14] SCANDAROLI, G. G. Controle adaptativo de juntas para uma prótese robótica de perna. Trabalho de graduação em Eng. de Controle e Automação. 2007.

[15] ALVES, E. d. S. Proposta de um módulo sensorial para estimação de postura com relação ao solo de uma prótese robótica de perna. Trabalho de graduação em Eng. de Controle e Automação. 2007.

[16] DELIS, A. L. et al. Algoritmo de estimação do ângulo do joelho para controle miolétrico. In: Anais do XXI Congresso Brasileiro de Engenharia Biomédica,. [S.l.: s.n.], 2008. v. 1, p. 1-5.

[17] DELIS, A. L. et al. Sistema para estimação de intenção de movimento em prótese de perna. In: Anais do XXI Congresso Brasileiro de Engenharia Biomédica,. [S.1.: s.n.], 2008. v. 1, p. 1-4.

[18] DELIS, A. L. et al. Development of a microcontrolled bioinstrumentation system for active control of leg prostheses. In: 30th Annual International Conference of the IEEE Engineering in Medicine and Biology Society. [S.1.: s.n.], 2008. v. 1, p. 2392-2396.

[19] FELIX, A. C. C.; VASCONCELLOS, H. A. S. Interpretação de sinais de EMG para joelho de prótese robótica. Trabalho de graduação em Eng. de Controle e Automação. 2008.

[20] BRASIL, D. A. Controle de orientação do pé de uma prótese robótica para amputados acima do joelho. Trabalho de graduação em Eng. de Controle e Automação. 2008.

[21] SCANDAROLI, G. et al. Adaptive knee joint control for an active amputee prosthesis. In: Latin American Robotics Symposium. [S.1.: s.n.], 2008.

[22] SCANDAROLI, G. G. Estimação em sistemas com restrições de igualdade e aplicaçôes em robótica móvel e de reabilitação. Dissertação (Mestrado) — Univeresidade de Brasília, 2009.

[23] DELIS, A. L. et al. Development of a myoelectric controller based on knee angle estimation. In: Procedings of the Second International Conference on Biomedical Electronics and Devices (BIODEVICES). [S.1.: s.n.], 2009. v. 1, p. 97-103.

[24] DELIS, A. L. et al. Estimation of the knee joint angle from surface electromyographic signals for active control of leg prostheses. Physiological Measurement, v. 30, n. 9, p. 931-946, Agosto 2009. Disponível em: <http://dx.doi.org/10.1088/0967-3334/30/9/005>.

[25] DELIS, A. L. et al. Myoelectric control algorithms for leg prostheses based on data fusion with proprioceptive sensors. In: ISSNIP Biosignals and Biorobotics Conference (BRC2010). [S.l.: s.n.], 2010.

[26] DELIS, A. L. et al. Knee angle estimation algorithm for myoelectric control. In: Biomedical Engineering Systems and Technologies. [S.1.]: Springer, 2010. cap. 2, p. 124-135.

[27] DELIS, A. L. Processamento de sinais de EMG para prótese robótica de perna. Tese (Doutorado) - Univeresidade de Brasília, 2010. 
[28] SCANDAROLI, G. G. et al. Foot pose estimation system for robotic leg prostheses. In: ISSNIP Biosignals and Biorobotics Conference (BRC2010). [S.1.: s.n.], 2010.

[29] ROCHA, T. S.; CHAURAIS, J. R.; MARTINS, C. P. Controle de impendância adaptativo do joelho de uma prótese de perna para amputações transfemurais. Trabalho de graduação em Eng. de Controle e Automação. Julho 2011.

[30] ÂNGELO, C. G. M. Desenvolvimento do sistema embarcado de uma prótese robótica para amputados transfemurais. Trabalho de graduação em Eng. de Controle e Automação. Dezembro 2012.

[31] PFEIFER, S.; RIENER, R.; VALLERY, H. An actuated transfemoral prosthesis with optimized polycentric knee joint. Proceedings of The Fourth IEEE RAS/EMBS International Conference on Biomedical Robotics and Biomechatronics.

[32] SAAD, M. e. a. Sinais clínicos associados a prognóstico de marcha em paralisia cerebral espástica. Revista Brasileira de Postura e Movimento, v. 1, n. 1, p. 5112-5116, 1997.

[33] PERRY, J. Gait Analysis: Normal and Pathological Function. 2. ed. [S.1.]: Slack Incorporated, 1992.

[34] CARVAlhO, J. A. Amputações de Membros Inferiores: Em Busca da Plena Reabilitação. 2. ed. [S.1.]: Manole, 2002.

[35] SCHMALZ, T.; BLUMENTRITT, S.; JARASCH, R. Energy expenditure and biomechanical characteristics of lower limb amputee gait: The influence of prosthetic alignment and different prosthetic components. Gait ES Posture, v. 16, n. 3, p. 225-263, 2002.

[36] TROWER, T. A. Changes in lower extremity prosthetic practice. Physical Medicine and Rehabilitation Clinics of North America - New Advances in Prosthetics and Orthotics, v. 17, n. 1, p. 23-30, 2006.

[37] BRUnNSTROM, S.; HOUGLUM, P. A.; BERTOTI, D. B. Brunnstroms Clinical Kinesiology. 6. ed. [S.1.]: F. A. Davis Company, 2012.

[38] HERR, H.; GRABOWSKI, A. Bionic ankle-foot prosthesis normalizes walking gait for persons with leg amputation. Proceedings of the Royal Society of London B: Biological Sciences, 2011.

[39] K SAGAWA Y JR, L. A. L. J. A. M. A. S. T. Comparison of the international committee of the red cross foot with the solid ankle cushion heel foot during gait - a randomized double-blind study. Archives of Physical Medicine and Rehabilitation, v. 94, n. 8, p. 1490 - 1497, 2013.

[40] TOFTS, L. J.; HAMBLIN, N. C-leg ${ }^{\circledR}$ improves function and quality of life in an adolescent traumatic trans-femoral amputee: A case study. Prosthetics and Orthotics International, v. 38, n. 5, p. 413-417, 2014. Disponível em: <http://poi.sagepub.com/content/38/5/413.abstract>.

[41] EBERLY, V. J. et al. Impact of a stance phase microprocessor-controlled knee prosthesis on level walking in lower functioning individuals with a transfemoral amputation. 
Prosthetics and Orthotics International, v. 38, n. 6, p. 447-455, 2014. Disponível em: $<$ http://poi.sagepub.com/content/38/6/447.abstract $>$.

[42] WOLF, E. J. et al. Comparison of the power knee and c-leg during step-up and sit-tostand tasks. Gait \&3 Posture, v. 38, n. 3, p. 397 - 402, 2013. ISSN 0966-6362. Disponível em: $<$ http://www.sciencedirect.com/science/article/pii/S096663621300009X >.

[43] KAHLE, J. T.; HIGHSMITH, M. J.; HUBBARD, S. L. Comparison of nonmicroprocessor knee mechanism versus c-leg on prosthesis evaluation questionnaire, stumbles, falls, walking tests, stair descent, and knee preference. Journal of Rehabilitation Research and Development, v. 45, n. 1, p. $1-14,2008$.

[44] SEGAL, A. et al. Kinematic and kinetic comparisons of transfemoral amputee gait using c-leg and mauch sns prosthetic knees. Journal of Rehabilitation Research and Development, v. 43, n. 7, p. 857-870, 2006.

[45] AU, S.; WEBER, J.; HERR, H. Biomechanical design of a powered ankle-foot prosthesis. In: Rehabilitation Robotics, 200\%. ICORR 200\%. IEEE 10th International Conference on. [S.l.: s.n.], 2007. p. 298-303.

[46] AU, S.; HERR, H. Powered ankle-foot prosthesis. Robotics Automation Magazine, IEEE, v. 15, n. 3, p. 52-59, September 2008. ISSN 1070-9932.

[47] GRABOWSKI, A.; D'ANDREA, S.; HERR, H. Bionic leg prosthesis emulates biological ankle joint during walking. [S.1.], 2011.

[48] GRABOWSKI, A.; D'ANDREA, S. Effects of a powered ankle-foot prosthesis on kinetic loading of the unaffected leg during level-ground walking. Journal of NeuroEngineering and Rehabilitation, 2013.

[49] ALDRIDGE, J. M.; STURDY, J. T.; WILKEN, J. M. Stair ascent kinematics and kinetics with a powered lower leg system following transtibial amputation. Gait 63 Posture, v. 36, n. 2, p. 291 - 295, 2012. ISSN 0966-6362. Disponível em: $<$ http://www.sciencedirect.com/science/article/pii/S0966636212001014>.

[50] GATES, D. H.; ALDRIDGE, J. M.; WILKEN, J. M. Kinematic comparison of walking on uneven ground using powered and unpowered prostheses. Clinical Biomechanics, v. 28, n. 4, p. 467 - 472, 2013. ISSN 0268-0033. Disponível em: <http://www.sciencedirect.com/science/article/pii/S0268003313000612>.

[51] LAI, J. C. K. et al. Prosthetic devices: Challenges and implications of robotic implants and biological interfaces. Proceedings of the Institution of Mechanical Engineers, Part H: Journal of Engineering in Medicine, v. 221, p. 173-183, 2007.

[52] BOGUE, R. Exoskeletons and robotic prosthetics: a review of recent developments. Industrial Robot: An International Journal, v. 36, n. 5, p. 421-427, 2009. 
[53] JIMéNEZ-FABIáN, R.; VERLINDEN, O. Review of control algorithms for robotic ankle systems in lower-limb orthoses prostheses, and exoskeletons. Medical Engineering $\mathcal{G}$ Physics, v. 34, p. $397-408,2012$.

[54] TUCKER, M. et al. Control strategies for active lower extremity prosthetics and orthotics: a review. Journal of NeuroEngineering and Rehabilitation, v. 12, n. 1, 2015.

[55] HITT, J. et al. The sparky (spring ankle with regenerative kinetics) project: Design and analysis of a robotic transtibial prosthesis. In: ASME International Design Engineering Technical Conference and Computers and Information in Engineering Conference. [S.l.: s.n.], 2007.

[56] Bellman, R. D.; HOlGate, M. A.; SUGAR, T. G. Sparky 3: Design of an active robotic ankle prosthesis with two actuated degrees of freedom using regenerative kinetics. In: 2nd Biennial IEEE/RAS-EMBS International Conference on Biomedical Robotics and Biomechatronics (Biorob). [S.l.: s.n.], 2008.

[57] SUP, F.; BOHARA, A.; GOLDFARB, M. Design and control of a powered transfemoral prosthesis. The International Journal of Robotics Research, v. 2, n. 27, p. 263-273, February 2008.

[58] PANG, L.; KAMATH, G.; WERELEY, N. Analysis and testing of a linear stroke magnetorheological damper. AIAA/ASME/AHS Adaptive Structures Forum, 1998.

[59] ZHU, X.; JING, X.; CHENG, L. Magnetorheological fluid dampers: A review on structure design andanalysis. Journal of Intelligent Material Systems and Structures, v. 23, n. 8, p. 839$873,2012$.

[60] KOO, J.-H.; GONCALVES, F. D.; AHMADIAN, M. A comprehensive analysis of the response time of mr dampers. Smart Materials and Structures, v. 15, p. 351-358, 2006.

[61] JOLLY, M. R.; BENDER, J. W.; CARLSON, J. D. Properties and applications of commercial magnetorheological fluids. Journal of Intelligent Material Systems and Structures, v. 10, 1999.

[62] GREENE, M. P. Four bar linkage knee analysis. Orthotics Prosthetics, v. 37, n. 1, p. 15-24, 1983.

[63] MURRAY, M.; DROUGHT, A.; KORY, R. Walking patterns of normal men. Journal of Bone E Joint Surgery, v. 46, n. 2, p. 335-360, March 1964.

[64] DIAZ, C. et al. An above-knee prosthesis with magnetorheological variable-damping. In: 5th IEEE RAS \& EMBS International Conference on Biomedical Robotics and Biomechatronics (BioRob). [S.l.: s.n.], 2014. 